Portland State University

PDXScholar

$1-1-1976$

\title{
Local government and manpower programs for the disadvantaged: an evaluation of the Portland Concentrated Employment Program
}

Lois Farrer Copperman

Portland State University

Follow this and additional works at: https://pdxscholar.library.pdx.edu/open_access_etds Let us know how access to this document benefits you.

Recommended Citation

Copperman, Lois Farrer, "Local government and manpower programs for the disadvantaged: an evaluation of the Portland Concentrated Employment Program" (1976). Dissertations and Theses. Paper 763.

https://doi.org/10.15760/etd.763

This Dissertation is brought to you for free and open access. It has been accepted for inclusion in Dissertations and Theses by an authorized administrator of PDXScholar. Please contact us if we can make this document more accessible: pdxscholar@pdx.edu. 


\author{
LOCAL GOVERNMENT AND MANPOWER PROGRAMS \\ FOR THE DISADVANTAGED: AN EVALUATION OF \\ THE PORTLAND CONCENTRATED EMPLOYMENT PROGRAM
}

\author{
by \\ LOIS FARRER COPPERMAN
}

\begin{abstract}
A thesis submitted to the Faculty of Urban studies in partial fulfillment of the requirements for the degree of
\end{abstract}

DOCTOR OF PHILOSOPHY

Portland State University 1976 
TO THE OFFICE OF GRADUATE STUDIES AND RESEARCH:

The members of the Committee approve the thesis of Lois Farrer Copperman, presented November 5, 1976.
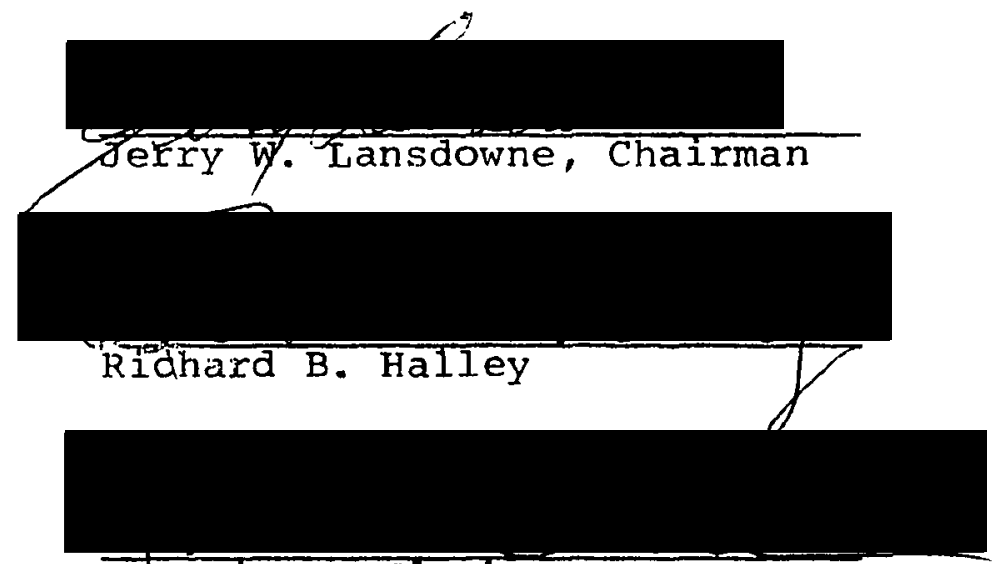

Quentin D. Clarkson

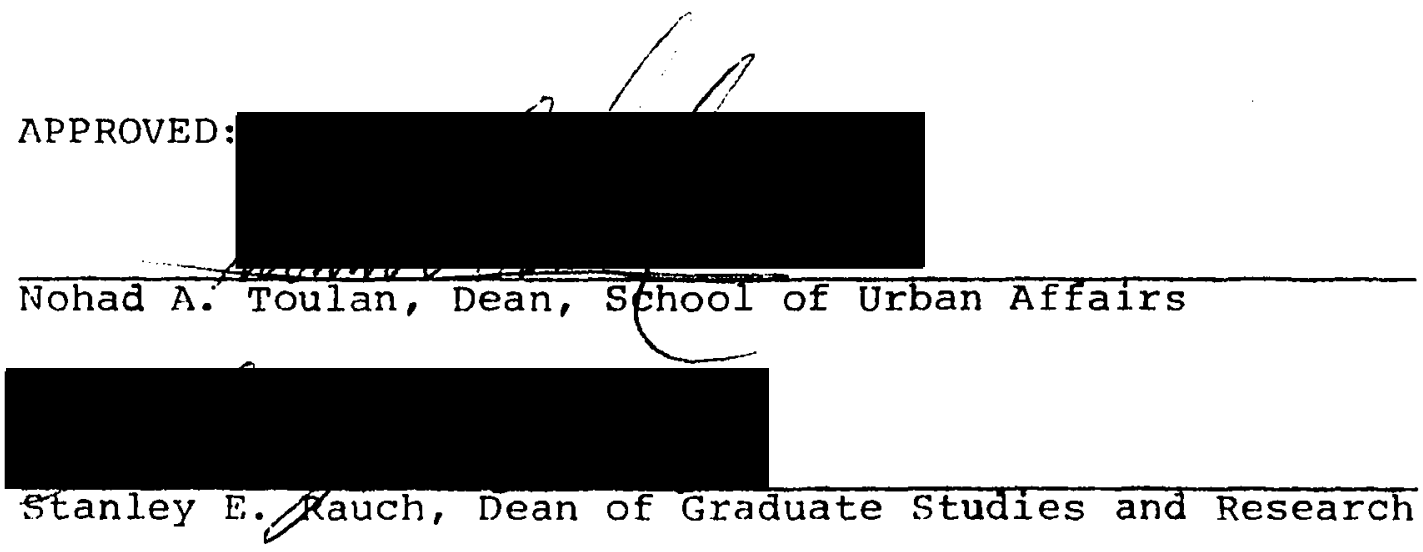


AN ABSTRACT OF THE THESIS OF Lois Farrer Copperman for the Doctor of Philosophy in Urban Studies presented November 5,1976 .

Title: Local Government and Manpower Programs for the Disadvantaged: An Evaluation of the Portland Concentrated Employment Program.

APPROVED BY MEMBERS OF THE THESIS COMMITTEE:

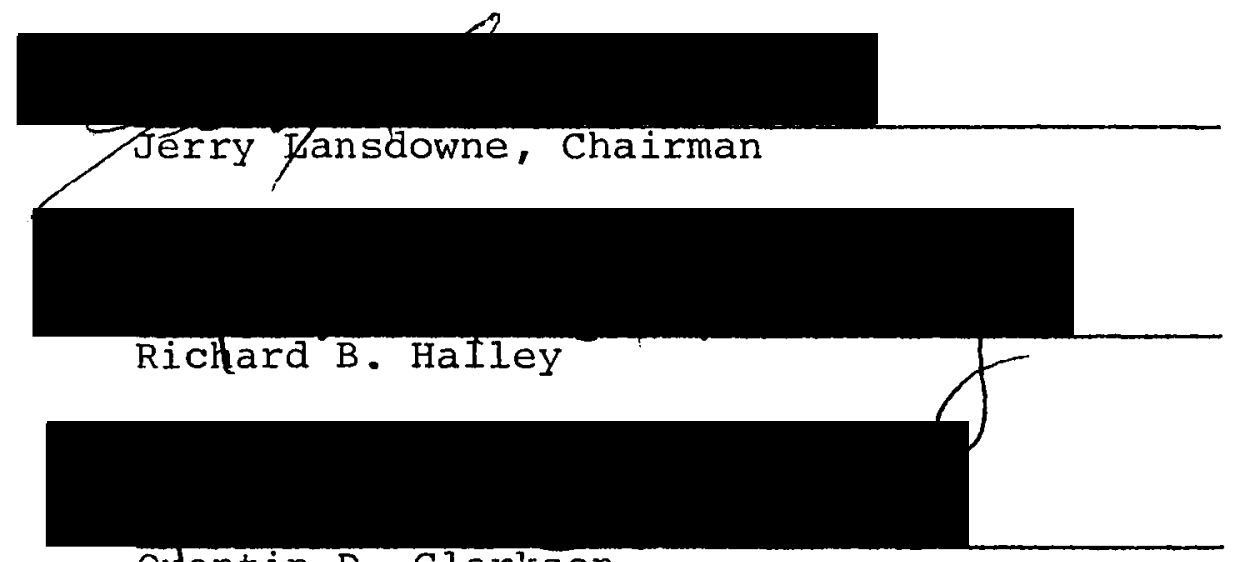

Quentin D. Clarkson

Manpower programs for the disadvantaged have been operated in the United States for approximately fifteen years. The programs - introduced under the authority of the Manpower Development and Training Act of 1961, the Economic Opportunity Act of 1964, the 1967 amendments to the Social Security Act, and the Comprehensive Training and Employment 
Act of 1973 - were all concerned with the employment and earning of certain groups. This body of legislation was intended to intervene in particular sectors of the labor market having a differentially high unemployment rate, not offset by higher wages and other benefits. The intent was to reduce labor market immobility due to geographical location, lack of skills, and age, sex or color discrimination. The ultimate objective of the manpower programs was to improve the employment and earnings experience of the disadvantaged target population. Little is presently known about the impact of the programs on the earnings and employment of participants after they leave the program. This retrospective study attempts to determine the impact of the Portland Concentrated Employment Program (PCEP) on the post-training incomes of 1985 PCEP participants and a control group of 1150 individuals applying to or enrolled in the PCEP between 1968 and 1972. The control group is a group of persons who are statistically equivalent to the participants as far as demographic variables and their application to and eligibility for the PCEP; but, who for some unknring reason, did not enter the program. Followup income information was purchased from the U.S. Social Security Administration in coded cells containing five or more individuals. The five digit numeric code classified individuals by participation or nonparticipation in the 
PCEP, sex, race, age, and education. The Analysis of Variance statistical technique was utilized in analyzing the 1973 mean earnings of the code groups included in the study. The analysis of the data resulted in the following major findings. Of the five independent variables - participation, sex, race, age, and education - there were significant interactions between participation, race, and age; participation and race; and sex and age. The first interaction is a result of Black participants and the White control group earning their highest incomes between the ages of 21-25 years. White participants and the Black control group had generally rising incomes as age increased up to 45 years. All groups 45 years and over earned low incomes relative to other groups in the study. The interaction between participation and race resulted from the Black control group in most cases earning more than all other groups in the study. Black participants earned slightly more than white participants. But, the White participant group appears to have benefitted more from participation in the PCEP, in comparison with the White control group, than did Black participants. Enrollment in the PCEP in most cases did not raise the incomes of participants significantly higher than the incomes of the control group. Sex and age demonstrated a significant interaction which was primarily due to the poor performance of males ages 45 and over. In all other age groups males earned significantly 
more than females. The groups with a high school degree and under 45 years of age earned significantly more than those without a high school degree. The education group benefitting most from participation in the PCEP included persons with 1-9 years of education.

Over seventy percent of the persons included in this study in both the participant and the control groups earned incomes below the official 1973 poverty level. Participation in the PCEP did not raise the mean earnings of groups studied above the poverty level. Considering income alone, approximately thirteen percent of the participants in comparison with their control groups are considered to have benefitted significantly from the PCEP. Six percent of the participants may have gained more benefit from continued labor market participation than from enrollment in the PCEP. The findings of this study indicate that the benefits to participants in the PCEP were not as substantial as expected. 
PREFACE

This dissertation was funded by U.S. Department of Labor Doctorial Dissertation Grant Number 91-41-75-16.

Certain data used in this dissertation were derived from statistics furnished by the U.S. Social Security Administration. The author did not at any time have access to any information relating to specific individuals or reporting units. The author assumes the full responsibility for the analysis and interpretation of the data.

The information concerning the functioning of the Comprehensive Employment \& Training Act of 1973 (CETA) in the Portland metropolitan area was obtained through taped interviews with city officials and manpower staff personnel in the metropolitan area, and the Executive secretary of the CETA Balance of state Prime sponsor for the state of oregon. The interviews took place during February and March 1975. Each subject taped was asked for permission to record the interview and all consented. One interview was not recorded. At the time of the interviews CETA VI was in the beginning stages of implementation. Consequently, the concentration of Chapters III \& IV is on the implications and effects of CETA Title I which authorized a decentralized, decategorized manpower system. Detailed observations 
on the operation of only two of the five prime sponsors in the Portland area are included. 


\section{$\therefore$ \\ ACKNOWLEDGEMENTS}

It is a pleasure to thank the members of my committee for their contributions to this work. Dr. Jerry Lansdowne, chairman, with characteristic consideration and perseverance was always available to offer stimulation, guidance, and advice. Dr. Quentin D. Clarkson with his expert knowledge of methodology contributed invaluable assistance in the quantitative portions of this work. Dr. Richard Halley offered constructive criticism and good counsel. I extend thanks to Charles white for his assistance and support.

This thesis would not have been possible without the assistance of Dell Smith, Director of the Portland Concentrated Employment Program. His willingness to open the files of the program to an outside researcher was unusual and commendable. I gratefully acknowledge his assistance and the cooperation of the staff of the Portland Concentrated Employment Program.

A special thank you is in order for my tolerant family; to my daughter, Leigh, and most of all to my husband, Jack, who listened patiently and always encouraged the continuation of this work. 


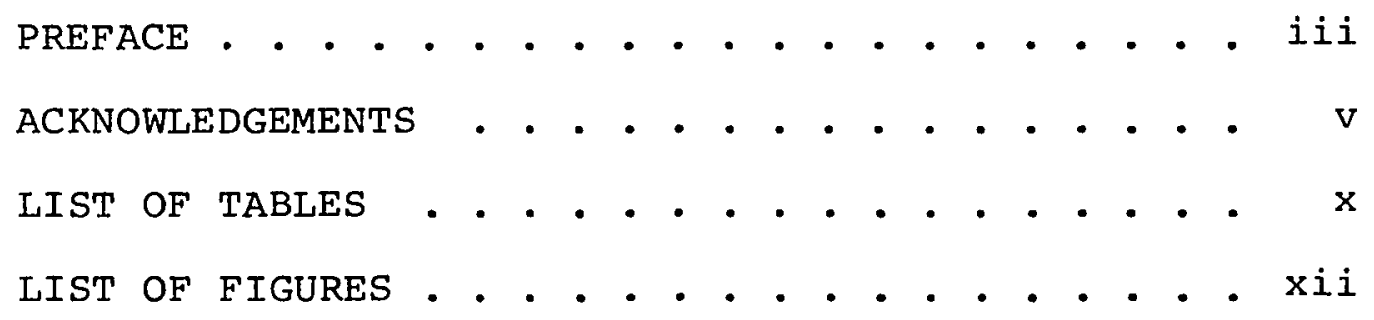

CHAPTER

I INTRODUCTION • • . . . . . . . . . . 1

Manpower Policy . . . . . . . 4

II HISTORICAL REVIEW OF MANPOWER POLICY • - 12

Suspension of Employment and
Manpower Policies . . . . . . 16

The Emergence of Manpower Programs . . . . . . . . . 24

Positive Manpower Policy Support Cycle

Economic Policy

Structural Unemployment: The Development of Manpower Policy . 29

The Manpower Development and Training Act

The Era of Social Engineering

Administrative Reform

Public Service Employment

Manpower Revenue Sharing 
TABLE OF CONTENTS (Continued)

PAGE

III THE COMPREHENSIVE EMPLOYMENT AND TRAINING ACT: DECENTRALIZATION, DECATEGORIZATION, AND THE DISADVANTAGED • • • • • • • • • 54

Decentralization . - . . . - 58

Decentralization in the Portlard Metropolitan Area

Decentralization and the Disadvantaged . . . . . . . 64

Allocations and the Disadvantaged in Portland, Oregon

Summary

IV THE COMPREHENSIVE EMPLOYMENT AND TRAINING ACT: PLANNING, ADMINISTRATION, AND ACCOUNTABILITY AT THE LOCAL LEVEL OF GOVERNMENT • • • • • • • • • • • • 80

Planning in the Portland Metropolitan Area

Administration Under CETA . . . . 87

Administration in the Portland Metropolitan Area

The Delivery System . . . . . . 92

The Delivery system in the Portland Metropolitan Area

Accountability . . . . . . 100

Summary . . . . . . . . 105

$\mathrm{V}$ THE IMPACT OF THE PORTLAND CONCENTRATED EMPLOYMENT PROGRAM • • • • • • • • . 109

The Portland Concentrated Employment Program and CETA . . . . . . 
TABLE OF CONTENTS (Continued)

CHAPTER

Research Design . . . . . . 117

The Control Group

Income Data

Problems in Using Social

Security Administration Data

The Dependent and Independent

Variables

Analysis of the Data . . . . . 133

A-Posteriori Tests

Sex and Age

Treatment and Race

Treatment, Age and Race

Education

Race and Education

Sex, Education and Treatment

Age and Education

Analysis with Zero Earners

and Those 45 Years and

Over Excluded . . . . . . . 159

Median Earnings 1973

Family Heads and Welfare

Recipients in the PCEP . . . . 168

Training Variables for PCEP Par-

ticipants and Mean Earnings . . 172

Type of service

Length of Stay in PCEP

Conclusions 
TABLE OF CONTENTS (Continued)

\section{CHAPTER}

PAGE

VI SUMMARY AND CONCLUSIONS . . . . . .

The Impact of the Portland

Concentrated Employment

Program on the Incomes of

Participants . . . . . . .

Benefits and Costs of

$$
\text { Participation }
$$

Persons 45 Years and Older

Sex

Education

Race

Recommended Modifications to

Improve the Effectiveness

of Manpower Programs . . . . 210

Institutional Barriers to Employment

Recommendations for CETA

Decision Makers 


\section{LIST OF TABLES}

TABLE

PAGE

I Employment Status of Noninstitutional Population 16 Years and over, Both Sexes: Annual Averages, 1947-73 . . . 18

IIA Unemployment Rates By Sex and Color For Persons 16 Years and Over, 1948-65. . . 20

IIB Unemployment Rates By Sex and Age, Annual Averages, 1947-65 . . . . . . 21

III Percent Fiscal Year 1975 of Fiscal Year 1974 Manpower Funds, By Type of Sponsor . . . . . . . . . .

IV Total CETA Money to Portland Metropolitan Area... . . . . . . . . 71

V City of Portland's CETA Money . . . . . . 98

VI Portland Concentrated Employment Program Budgets and Enrollments: 1968-1974 . . 113

VII Independent Variables, PCEP Participants and Control Group, 1968-1972 . . . . . 126

VIII F-Tests For Interaction For Fixed Effects Model . . . . . . . . . 136

IX F-Tests For Main Effects For Fixed Effects Model . . . . . . . . .

X Zero Earners and Persons 45 Years and Over Excluded: F-Tests For Main Effects For Fixed Effects Model

XI Mean Earnings By Code Group 1973: Zero Earners and Persons 45 Years and Over Excluded . . . . . . . . 163

XII PCEP Participants Reported as "Head of Family" and "Welfare Recipient" By Percent of Code Group . . 170 
LIST OF TABLES (Continued)

TABLE

PAGE

XIII Second Code: PCEP Participants only . . . 174

XIV 1973 Mean Earnings By Year Training Was Completed in PCEP . . . . . . 175

XV Education of Participants by Year PCEP Completed: By Percent. . . . . . 177

XVI Mean Earning 1973 By Years of Education and Year PCEP Completed . . . . . . 177

XVII Mean Earnings By Type of Training: By Percent . . . . . . . . . . 179

XVIII Mean Earnings By Type of Service: By Percent . . . . . . . . . . . . 179

XIX Type of Training By Year Completed: By Percent... . . . . . . . . 181

XX Length of Stay and Mean Earnings 1973 By Year Completed . . . . . . 182

XXI Percent of Participants in "Length of Stay" Category By Year Completed: . 


\section{LIST OF FIGURES}

FIGURE

PAGE

1 The Policy-Making Cycle . . . . . . . . 25

2 Amounts Authorized for Program Activities Under the Comprehensive Employment and Training Act, Fiscal Year 1975 . . . . . 57

3 Mean Profiles for Treatment and Age by Race . . . . . . . . . . . . . 139

4 Mean Profiles for Treatment and Race by Age... . . . . . . . . . . . 140

5 Mean Profiles for Race and Age by Treatment . . . . . . . . . . . 141

6 Mean Profiles for Treatment and Race . . . 142

7 Mean Profiles for Sex and Age . . . . . . 143

8 Mean Profile for Education . . . . . . . . 144 


\section{CHAPTER I}

\section{INTRODUCTION}

The major purpose of this dissertation is to evaluate the impact of the Portland Concentrated Employment Program (CEP) on participants in tra manpower program. Income information on CEP participants between 1968 through 1972 and a control group was obtained from the U.S. Social Security Administration. The analysis and the findings are covered in Chapters $\mathrm{V}$ and VI of the dissertation. The Concentrated Employment Program is one of many programs which are subsumed under the general category of manpower policy. To relate the Concentrated Employment Program to the body of manpower policy, the first chapters of the dissertation present a historical review of the evolution of manpower policy in the United states during the last fifty years. This review reveals three major periods in which the focus or organization of manpower policies underwent significant changes. The first period, which spans the years from 1930 until the late 1950's, marked the beginning of a national concern legitimized through legislation about unemployment levels. The New Deal and the Employment Act of 1946 are the major legislative milestones during this period. The second stage occurred during the 
decade from approximately 1960 to 1970. High and seemingly stable unemployment rates among the disadvantaged were combined with the optimistic belief at the federal governmental level, that centrally administered programs providing training, education, and placement would provide the desired impact on the problems of structural unemployment. The programs were expected to raise the incomes and employment rates of participants. The Manpower Development and Training Act of 1961 was the major piece of legislation passed during this decade. Gradual disillusionment with the federal programs occurred during the second half of the decade. Various attempts to consolidate and coordinate the manpower programs while maintaining federal control were unsuccessful in significantly reducing the problems. The creation of the Concentrated Employment Program was an example of the federal attempt to reduce the confusion, fragmentation, and duplication which characterized the manpower delivery system in the late $1960^{\prime} \mathrm{s}$. But, for various reasons discussed in the body of the dissertation, a workable efficient federally administered manpower system appeared doomed to failure. The continuing problems led federal policymakers to search for alternative methods of service delivery. After lengthy consideration national elected officials chose to decentralize and decategorize manpower programs. The resulting third stage which reaches up to the present time, is characterized by the shift in control of manpower programs from 
the federal to the state and local levels. The major legislation empowering the shift in the delivery system was the Comprehensive Employment and Training Act of 1973 (CETA). Chapters III and IV discuss the expectations of CETA's sponsors and the functioning of the new CETA programs operating in the Portland, Oregon, metropolitan area.

This dissertation attempts to examine the manpower policy area from the framework of policy analysis. The emphasis is placed on the identification of the manpower problem, the formulation of a course of action, the legitimation of the policy, the application of the policy, evaluation, and feedback into the policy process. The evaluation of the impact of the Portland CEP program is considered a necessary and important part of the policy-making process. Although the method of delivering manpower services has shifted, the basic assumption that manpower programs providing a group of services can have a positive impact on the long-term incomes and employment of the disadvantaged participant has not been adequately examined. The analysis of the impact of CEP on its participants provides new information which may be of use to decision makers when considering changes in future manpower programs. The evaluation of the Portland CEP should have particular relevance to planners for Portland CETA programs which are currently based on the CEP model and include participants from the same geographic area. 
MANPOWER POLICY

The word "manpower" is a fairly recent addition to the vocabulary, but in the largest sense we have always had manpower policies - policies affecting the size, skills, and disposition of the working force. Immigration, slavery, land laws, and universal education were all at their heart 1 manpower policies. A clear definition of manpower policy is made difficult by its overlap with many other policy areas, particularly economic and education policies. It is possible to separate, in concept at least, education and economic policy from manpower policy by examining the emphases and primary goals which have emerged in these areas over time.

Education policy in the United States has been concerned primarily with general education and literacy levels. The primary goal of education is to teach people to think, not to prepare them for employment. Little emphasis in education has been placed on developing skills training for specific occupations.

General economic policy, using the federal government's fiscal and monetary tools, has concentrated on monitoring and influencing the aggregate levels of demand and supply in the general economy, as well as aggregate unemployment levels. Fiscal and monetary tools, which include regulation of the quantity of money circulating in the 
economy and the manipulation of federal government expenditures and revenues, have been perceived by policy-makers as affecting both aggregate unemployment levels and inflation. The development of manpower policy in the early 1960's was an outcome of national political leaders' reluctance to employ an aggressive fiscal policy to lower high aggregate unemployment levels. The primary reason for the hesitation was the fear that expansionary monetary and fiscal policies would lead to price increases and spiralling inflation. Alternatively, national leaders pursued a policy intended to intervene in the more narrowly defined problems of structural unemployment. This legislation became the foundation of present manpower policy. "Structural unemployment exists in particular sectors of the labor market having differentially high unemployment rates when these differentials are not offset by relatively high wages or other advantages, and workers find it difficult or impossible to move to sectors with lower unemployment rates." Immobility which may be due to geographical location; lack of skills; or age, sex, and color barriers is an essential feature of structural unemployment. Consequently, manpower policies intended to reduce structural unemployment are aimed more at specific sectors of the labor force and are concerned more with the employment and employability of particular individuals and groups, than aggregate levels of employment. The goals of manpower policy, which may include 
increasing clients' literacy levels or reducing unemployment within target areas, are more specific than the goals of economic policy. Nevertheless, economic policy is inextricably tied to manpower policy in that economic policies invariably affect the number and availability of jobs. Aggregate unemployment levels determine the number and quality of applicants for job openings. Thus, different manpower intervention strategies are more likely to benefit the victims of structural unemployment during favorable economic cycles than during recessions and vice versa. The development of mechanisms to integrate economic, education, and manpower policies is an administrative function within the Executive Branch of the government.

Very broadly the goals of manpower policy are to develop employment opportunities for all who want them, to improve the skills of the labor force, and to match the labor supply to the demand for labor. More specifically, manpower policy in the last decade has been primarily concerned with increasing the skills, incomes, job opportunities, and length of employment among the disadvantaged population. Manpower programs have attempted to provide education, occupational skills, counselling, and job placement for that portion of the labor force which has historically been at the end of the labor queue. In attempting to open the door for the disadvantaged workers in the private 
sector or in creating new jobs in the public sector, manpower policy is directed at the demand side of the economic equation. In providing education and marketable skills which lead to gainful employment, it focuses on the supply side. By improving the imperfect functioning of the labor market through providing information to employers and applicants and by matching men with jobs, it bridges the gap between supply and demand. In brief, manpower policy attempts to assure individual access to available and expanding opportunities.

For the most part in the United States since the $1930^{\prime} \mathrm{s}$, public manpower policies work at the margin of the labor market. For the majority of citizens, the labor market works fairly well without government intervention. Most of the population manages to obtain education and skills with which they successfully compete in the labor market, without enrolling or participating in a government manpower program. "Manpower decisions are made by individuals, families, schools, employers and unions, in that order, with public manpower programs playing a minor role." 5 In reality, the decisions to increase or decrease government spending in such areas as defense, research and technology, agricultural subsidies, and public works, although outside of the boundaries of manpower legislation, have a much greater impact on both the structure and the level of demand in the labor market than do all the manpower training programs. 
There is no federal manpower policy in a strict, dictionary sense. Policy implies more than the existence of programs which have some impact on a problem. A policy requires identification of a significant public problem; explicit recognition of goals; the formulation of a definite plan of action selected from among alternatives to realize those articulated goals; and an evaluation of the policy with feedback into the decision-making process.

In the U.S. manpower policy, insofar as it exists, has evolved incrementally over time. Programs have been instituted more or less one at a time in response to a particular crisis or a newly identified problem. ${ }^{6}$ Elected officials have tended to look for specific solutions to particular problems rather than developing a comprehensive and integrated manpower policy. Consequently, rather than a coherent federal manpower policy, there are a large number of programs and policies that have been instituted and from which general manpower policy emphases can be extracted.

Several assumptions appear to underlie federal manpower legislation. The basic assumption is the belief in the "work ethic", i.e. that it is better to provide jobs or income for work performed than to provide unearned income. Furthermore, the manpower legislation passed since 1960 has the following general theme: "People who can work should work; jobs are available if workers are adequately prepared; training and education can provide the needed preparation, 
for those with severe problems; and employment, increased income and greater self-esteem - which are the expected benefits gained from participation in the program - will be worth far more in the long run than the cost of remedial attention." 8

The underlying theory assumes that generally training and economic incentives will be sufficient to overcome historical labor market discrimination against certain groups, as well as possible innate or environmentally determined individual differences which resulted in the clients' need for manpower services in the first place. Manpower programs would presumably effect the necessary changes to allow participants to enjoy the benefits accruing to those in the mainstream of the American labor force.

The favorable economy and low unemployment rate between 1965 and 1969 reinforced these assumptions. During this period a large majority of manpower clients found jobs in private sector employment. But, as unemployment rose in 1970, private sector placements for the disadvantaged became increasingly difficult. Participants placed in better times were laid off or fired. Passage of the Emergency Employment Act of 1971 and Title VI of CETA in 1974, both of which created public service jobs for the unemployed, held an implied recognition that perhaps the expectations of the private labor market were unrealistic. Publicly funded jobs were considered necessary to reduce the unemployment rates. 
But, the continued belief in work for income received, was present in both pieces of legislation.

The postulates which provide the foundation for present manpower policy have evolved in the approximately forty year period in which unemployment has been perceived as a legitimate concern for public policy. Chapter II attempts to trace the evolution of manpower programs through the policy-making process in the United States. 
1. Roger H. Davidson, The Politics of Comprehensive Manpower Legislation (Baltimore: Johns Hopkins University Press, 1972), p. 1 .

2. Garth I. Mangum, "The Development of Manpower Policy, 1961-65", Dimensions of Manpower Policy: Programs and Research, ed. Sar A. Levitan and Irving Siegel (Baltimore: Johns Hopkins University Press, 1966), p. 29.

3. Lloyd Ulman, ed. Manpower Programs in the Policy Mix (Baltimore: Johns Hopkins Press, 1973), p. 26.

4. U.S., Congress, Senate, Subcommittee on Employment and Manpower of the committee on Labor and Public Welfare, United States Senate, Toward Full Employment: Proposals for a Comprehensive Employment and Manpower Policy in the United States, 88 th Cong., 2nd Sess., 1964, p. 38 .

5. Garth I. Mangum, The Emergence of Manpower Policy (New York: Holt, Rinehart and Winston, Inc., 1969), p. 8 .

6. Ibid., p. 130 .

7. Ibid.

8. Sar A. Levitan and Robert Taggert III, Social Experimentation and Manpower Policy: The Rhetoric and the Reality (Baltimore: Johns Hopkins Press, 1971), p. 96.

9. Ibid., p. 98. 
CHAPTER II

\section{HISTORICAL REVIEW OF MANPOWER POLICY}

In 1921 President Harding presumably expressed the attitude of the federal government in his welcoming speech to the President's Conference on Unemployment. He stated, "There has been vast unemployment before and there will be again. There will be depression and inflation just as surely as the tides ebb and flow. I could have little enthusiasm for any proposed remedy which seeks either palliation or tonic from the Public Treasury." ${ }^{10}$ The general level of employment and the functioning of the economy were considered outside the bounds of appropriate government business. Unemployment was considered a private problem, and individuals faced with the loss of their jobs, turned to families, friends, or private charities for aid.

Official policy remained unchanged until 1933. But, basic social and economic changes were altering the public and political opinions concerning the appropriate role of the government in economic decisions. Between 1929 and 1931 unemployment in the U.S. rose spectacularly - from between three and four percent of the labor force to approximately sixteen percent. During the depth of the Depression in 
1933, approximately one quarter of the labor force was, 11

unemployed. Industrialization and urbanization had caused economic and social changes in the structure of society. A constantly increasing portion of the labor force had become dependent upon wage and salary income. The decline of the extended family and increased geographic mobility, left unemployed individuals increasingly isolated from traditional means of support during periods of personal or national economic crisis. Private charities were unable to cope with the large numbers of unemployed people in need of services. Gradually many different individuals and groups began to perceive unemployment, not as a private problem affecting only individuals directly engaged in the transaction, but as a public problem which affects others not immediately concerned. Unemployment was newly perceived as a public problem requiring government attention and intervention. The Administration of Franklin D. Roosevelt responded and placed the issue of federal responsibility for employment levels on the national political agenda for the first time. This was a highly significant step in the development of manpower policy. The great majority of the concerns of the political policymaking process are previously defined and accepted issue areas. The Roosevelt Administration's formulation of unemployment as a public issue requiring federal intervention was an example of what Charles Lindblom describes as a "giant step" infrequent in the policy process 
13

which only rarely considers "new problems".

Franklin D. Roosevelt after a brief commitment to the traditional balanced budget, developed a course of action which included unprecedented programs for both relief and public works - at the same time that other measures were taken to stimulate economic recovery. In retrospect, the revolutionary New Deal consisted of few basic reforms. Only two pieces of permanent legislation in the manpower area emerged from the Depression. The Wagner-Peyser Act established the United States Employment Service as a joint federal-state system operated with federal matching grants and aimed at linking unemployed men with jobs. The Social Security Act of 1935 established a federal-state system of unemployment insurance for jobless workers. Other legislative and administrative efforts under the New Deal were temporary in nature - such as the Civilian Conservation Corps, the Public Works Administration, and the Works Progress Administration. The measures were inadequate considering the magnitude of the problem. The national unemployment rate in 1940 was still in the range of fifteen percent.

But, the importance of the New Deal is not measured only by the immediate effectiveness of its programs. The New Deal legitimized government intervention in the economy and established unemployment as a rightful area of government concern. Machinery was set up to administer, evaluate 
and reformulate employment policy. The first great hurdle in the policy process had been passed. Problems introducing new legislation in this area were greatly reduced.

The New Deal marked the end of the notion that the federal government should not interfere in the economy. The theoretical rationale for the government assuming active responsibility for economic policy was provided by John Maynard Keynes' The General Theory of Employment, Interest, and Money. Keynes argued that government should pursue an active fiscal policy, effecting total spending by tax changes or government expenditures. Employment depends on the level of aggregate demand, and government, through its economic policies, can influence aggregate demand to generate jobs for all who want to work. The experience of World War II demonstrated the responsiveness of employment levels to federal expenditures. Federal expenditures in 1943 nearly equaled the total spent between 1929-1941. Unemployment dropped from fifteen percent in 1940 to 1.2 percent in 1944 .

As the war came to an end, there was widespread fear, reinforced by memories of the recent Depression, that conversion to a peacetime economy would create considerable unemployment. Prompted by such fears and recognizing the effectiveness of government activity in eliminating unemployment during the war, Senator James E. Murray and others introduced legislation to ensure a public commitment to full 
employment. As it finally emerged from Congress in 1946, the Employment Act did not guarantee jobs as its liberal sponsors had hoped. It did, however, declare a federal policy of promoting maximum employment, production, and purchasing power, and legitimized continued federal government concern over employment levels. It placed on public record a broad federal responsibility for this area. The legislation was also important in establishing the council of Economic Advisors (CEA) who were to prepare an annual report on the economic state of the nation to be delivered by the President and were to advise the President whenever unemployment or inflation were becoming serious problems. The Employment Act also created the permanent Joint Economic 18

Committee of Congress. The existence of the CEA insured continuing expert analysis of the economy. The Joint Committee in Congress, investigating reports and evolving new legislation, guaranteed continued congressional interest in unemployment levels and its continuing place on the federal political agenda.

\section{SUSPENSION OF EMPLOYMENT AND MANPOWER POLICIES}

The Employment Act of 1946 was the last major piece of legislation dealing with employment to be passed by Congress until 1961. Gradually, as the country returned to peacetime without the feared economic relapse, the concern for full employment slipped down on the level of priorities. The 
antiunemployment consensus dissolved as Congressmen turned their attention to other areas.

Unemployment was not at a satisfactory level during the postwar decade. The Council of Economic Advisors in 1947 suggested a moderate goal of four percent unemployment as a satisfactory level. This figure was reiterated as a target goal by both the Fisenhower and the Kennedy Administrations. Table I indicates that the U.S. failed, and often by a wide margin to achieve the goal of four percent total unemployment.

Given levels of unemployment above four percent and the philosophy expressed in the Employment Act of 1946, why was no legislation passed during this period to alleviate unemployment? The following factors were important in discouraging the necessary majority building which precedes the passage of legislation through Congress:

- Throughout his eight years in office from 1952-1960, President Eisenhower was predominantly concerned with inflation and strongly opposed federal spending for employment programs. Congressional majority building is a very difficult task in the face of a threatened Presidential veto.

- The climate of political opinion in the early 1950's was strongly influenced by the rhetoric surrounding the McCarthy Hearings, the Cold War with the USSR, and the Korean War. A free economy and the free enterprise 
EMPLOYMENT STATUS OF THE NONINSTITUTIONAL POPULATION

16 YEARS AND OVER, BOTH SEXES:

ANNUAL AVERAGES, 1947-73

Year

1947

1948

1949

1950

1951

1952

1953

1954

1955

1956

1957

1958

1959

1960

1961

1962

1963

1964

1965

1966

1967

1968

1969

1970

1971

1972

1973
Percent of Civilian Labor Force Unemployed

3.9

3.8

5.9

5.3

3.3

3. 0

2.9

5.5

4.4

4.1

4.3

6.8

5.5

5.5

6.7

5.5

5.7

5.2

4.5

3.8

3.8

3.6

3.5

4.9

5.9

5.6

4.9

Source: 1974 Manpower Report of the President, (Washington, D.C.: U.S. Government Printing Office, 1974), $p$. 271 and 272 . 
system were idealized. Support for government intervention in the economy temporarily declined.

- Politicians are generally more responsive to registered voters than to other sectors of their constituency. The distribution of unemployment in the period between 1947-1957 was uneven. Those hardest hit by unemployment were also an ineffectual portion of the electorate during that period. As demonstrated in Table II the unemployment rate for Blacks and teenagers was consistently much higher than that of the general population.

Individual Congressmen, particularly those representing areas with higher than normal unemployment rates, continued a high priority interest in unemployment intervention legislation. But, the majority coalition necessary to formulate and pass such legislation could not be obtained.

In 1958 the country was in its third postwar recession, and by April the unemployment level had reached 7.4 percent. Unemployment among white males, an important voting group, rose to 6.1 percent.

Republicans, facing elections in Fall 1958, as well as Democrats in the Congress, were increasingly concerned in the high levels of unemployment and the recurring recessions. An antiunemployment consensus was slowly being rebuilt. No fully conceived economic or manpower programs were offered 
TABLE II-A

UNEMPLOYMENT RATES BY SEX AND COLOR FOR PERSONS 16 YEARS AND OVER:

Annual Averages, 1948-65

\begin{tabular}{|c|c|c|c|c|c|c|c|c|c|}
\hline & Total & Male & Female & Total & $\begin{array}{l}\text { White } \\
\text { Male }\end{array}$ & Female & $\begin{array}{l}\text { Negro } \\
\text { Total }\end{array}$ & $\begin{array}{c}\text { and other } \\
\text { Male }\end{array}$ & $\begin{array}{l}\text { Races } \\
\text { Female }\end{array}$ \\
\hline $\begin{array}{l}1948 \\
1949 \\
1950 \\
1951 \\
1952 \\
1953 \\
1954 \\
1955 \\
1956 \\
1957 \\
1958 \\
1959 \\
1960 \\
1961 \\
1962 \\
1963 \\
1964 \\
1965\end{array}$ & $\begin{array}{l}3.8 \\
5.9 \\
5.3 \\
3.3 \\
3.0 \\
2.9 \\
5.5 \\
4.4 \\
4.1 \\
4.3 \\
6.8 \\
5.5 \\
5.5 \\
6.7 \\
5.5 \\
5.7 \\
5.2 \\
4.5\end{array}$ & $\begin{array}{l}3.6 \\
5.9 \\
5.1 \\
2.8 \\
2.8 \\
2.8 \\
5.3 \\
4.2 \\
3.8 \\
4.1 \\
6.8 \\
5.3 \\
5.4 \\
6.4 \\
5.2 \\
5.2 \\
4.6 \\
4.0\end{array}$ & $\begin{array}{l}4.1 \\
6.0 \\
5.7 \\
4.4 \\
3.6 \\
3.3 \\
6.0 \\
4.9 \\
4.8 \\
4.7 \\
6.8 \\
5.9 \\
5.9 \\
7.2 \\
6.2 \\
6.5 \\
6.2 \\
5.5\end{array}$ & $\begin{array}{l}3.5 \\
5.6 \\
4.9 \\
3.1 \\
2.8 \\
2.7 \\
5.0 \\
3.9 \\
3.6 \\
3.8 \\
6.1 \\
4.8 \\
4.9 \\
6.0 \\
4.9 \\
5.0 \\
4.6 \\
4.1\end{array}$ & $\begin{array}{l}3.4 \\
5.6 \\
4.7 \\
2.6 \\
2.5 \\
2.5 \\
4.8 \\
3.7 \\
3.4 \\
3.6 \\
6.1 \\
4.6 \\
4.8 \\
5.7 \\
4.6 \\
4.7 \\
4.1 \\
3.6\end{array}$ & $\begin{array}{l}3.8 \\
5.7 \\
5.3 \\
4.2 \\
3.3 \\
3.1 \\
5.6 \\
4.3 \\
4.2 \\
4.3 \\
6.2 \\
5.3 \\
5.3 \\
6.5 \\
5.5 \\
5.8 \\
5.5 \\
5.0\end{array}$ & $\begin{array}{r}5.9 \\
8.9 \\
9.0 \\
5.3 \\
5.4 \\
4.5 \\
9.9 \\
8.7 \\
8.3 \\
7.9 \\
12.6 \\
10.7 \\
10.2 \\
12.4 \\
10.9 \\
10.8 \\
9.6 \\
8.1\end{array}$ & $\begin{array}{r}5.8 \\
9.6 \\
9.4 \\
4.9 \\
5.2 \\
4.8 \\
10.3 \\
8.8 \\
7.9 \\
8.3 \\
13.8 \\
11.5 \\
10.7 \\
12.8 \\
10.9 \\
10.5 \\
8.9 \\
7.4\end{array}$ & $\begin{array}{r}6.1 \\
7.9 \\
8.4 \\
6.1 \\
5.7 \\
4.1 \\
9.3 \\
8.4 \\
8.9 \\
7.3 \\
10.8 \\
9.4 \\
9.4 \\
11.8 \\
11.0 \\
11.2 \\
10.6 \\
9.2\end{array}$ \\
\hline
\end{tabular}

Source: 1974 Manpower Report of the President, (Washington, D.C.: U.S. Government Printing office, 1974), p. 271 and 272. 
TABLE II-B

UNEMPLOYMENT RATES BY SEX AND AGE: Annual Averages, 1947-65

$\begin{array}{ccccccccc}\text { Total } & 16 \underset{17}{*} 17 & 18 \& 19 & 20-24 & 25-34 & 35-44 & 45-54 & 55-64 & 67 \text { Yrs } \\ \text { \& Over } & \text { Yrs } & \text { Yrs } & \text { Yrs } & \text { Yrs } & \text { Yrs } & \text { Yrs } & \text { Yrs } & \text { \& Over }\end{array}$

MALE

\begin{tabular}{|c|c|c|c|c|c|c|c|c|c|}
\hline $\begin{array}{l}1947 \\
1948 \\
1949 \\
1950 \\
1951 \\
1952 \\
1953 \\
1954 \\
1955 \\
1956 \\
1957 \\
1958 \\
1959 \\
1960 \\
1961 \\
1962 \\
1963 \\
1964 \\
1965\end{array}$ & $\begin{array}{l}4.0 \\
3.6 \\
5.9 \\
5.1 \\
2.8 \\
2.8 \\
2.8 \\
5.3 \\
4.2 \\
3.8 \\
4.1 \\
6.8 \\
5.3 \\
5.4 \\
6.4 \\
5.2 \\
5.2 \\
4.6 \\
4.0\end{array}$ & $\begin{array}{r}10.3 \\
10.1 \\
13.7 \\
13.3 \\
9.4 \\
10.5 \\
8.8 \\
13.9 \\
12.5 \\
11.7 \\
12.4 \\
16.3 \\
15.8 \\
15.5 \\
18.3 \\
15.9 \\
18.8 \\
17.1 \\
16.1\end{array}$ & $\begin{array}{r}11.3 \\
9.6 \\
14.6 \\
12.3 \\
7.0 \\
7.4 \\
7.2 \\
13.2 \\
10.8 \\
10.4 \\
12.3 \\
17.8 \\
14.9 \\
15.0 \\
16.3 \\
13.8 \\
15.9 \\
14.6 \\
12.4\end{array}$ & $\begin{array}{r}8.5 \\
6.9 \\
10.4 \\
8.1 \\
3.9 \\
4.6 \\
5.0 \\
10.7 \\
7.7 \\
6.9 \\
7.8 \\
12.7 \\
8.7 \\
8.9 \\
10.7 \\
8.9 \\
8.8 \\
8.1 \\
6.3\end{array}$ & $\begin{array}{l}3.4 \\
2.8 \\
5.2 \\
4.4 \\
2.3 \\
2.2 \\
2.2 \\
4.8 \\
3.3 \\
3.3 \\
3.3 \\
6.5 \\
4.7 \\
4.8 \\
5.7 \\
4.5 \\
4.5 \\
3.5 \\
3.0\end{array}$ & $\begin{array}{l}2.6 \\
2.4 \\
4.3 \\
3.6 \\
2.0 \\
1.9 \\
2.0 \\
4.1 \\
3.1 \\
2.6 \\
2.8 \\
5.1 \\
3.7 \\
3.8 \\
4.6 \\
3.6 \\
3.5 \\
2.9 \\
2.6\end{array}$ & $\begin{array}{l}2.6 \\
2.5 \\
4.3 \\
4.0 \\
2.4 \\
2.2 \\
2.3 \\
4.3 \\
3.2 \\
3.0 \\
3.3 \\
5.3 \\
4.1 \\
4.1 \\
4.9 \\
3.9 \\
3.6 \\
3.2 \\
2.5\end{array}$ & $\begin{array}{l}2.9 \\
3.1 \\
5.4 \\
4.9 \\
2.8 \\
2.4 \\
2.8 \\
4.5 \\
4.3 \\
3.5 \\
3.5 \\
5.5 \\
4.5 \\
4.6 \\
5.7 \\
4.6 \\
4.3 \\
3.9 \\
3.3\end{array}$ & $\begin{array}{l}2.8 \\
3.4 \\
5.1 \\
4.8 \\
3.5 \\
3.0 \\
2.4 \\
4.4 \\
4.0 \\
3.5 \\
3.4 \\
5.2 \\
4.8 \\
4.2 \\
5.5 \\
4.6 \\
4.5 \\
4.0 \\
3.5\end{array}$ \\
\hline
\end{tabular}

FEMALE

\begin{tabular}{|c|c|c|c|c|c|c|c|c|c|}
\hline $\begin{array}{l}1947 \\
1948 \\
1949 \\
1950 \\
1951 \\
1952\end{array}$ & $\begin{array}{l}3.7 \\
4.1 \\
6.0 \\
5.7 \\
4.4 \\
3.6\end{array}$ & $\begin{array}{r}9.8 \\
9.8 \\
14.4 \\
14.2 \\
10.0 \\
9.1\end{array}$ & $\begin{array}{r}6.8 \\
7.4 \\
11.2 \\
9.8 \\
7.2 \\
7.3\end{array}$ & $\begin{array}{l}4.6 \\
4.9 \\
7.3 \\
6.9 \\
4.4 \\
4.5\end{array}$ & $\begin{array}{l}3.6 \\
4.3 \\
5.9 \\
5.7 \\
4.5 \\
3.6\end{array}$ & $\begin{array}{l}2.7 \\
3.0 \\
4.7 \\
4.4 \\
3.8 \\
3.0\end{array}$ & $\begin{array}{l}2.6 \\
3.0 \\
4.0 \\
4.5 \\
3.5 \\
2.5\end{array}$ & $\begin{array}{l}2.6 \\
3.1 \\
4.4 \\
4.5 \\
4.0\end{array}$ & $\begin{array}{l}2.2 \\
2.3 \\
3.8 \\
3.4 \\
2.9\end{array}$ \\
\hline
\end{tabular}


TABLE II-B (Continued)

$\begin{array}{cccccccc}\text { Total } & 16 \& 17 & 18 \text { \& } 19 & 20-24 & 25-34 & 35-44 & 45-54 & 55-64 \\ \text { \& Over } & \text { Yrs } & \text { Yrs } & \text { Yrs } & \text { Yrs } & \text { Yrs } & \text { Yrs } & \text { Yrs }\end{array}$

\section{F'EMALE}

\begin{tabular}{|c|c|c|c|c|c|c|c|c|c|}
\hline $\begin{array}{l}1953 \\
1954 \\
1955 \\
1956 \\
1957 \\
1958 \\
1959 \\
1960 \\
1961 . \\
1962 \\
1963 \\
1964 \\
1965\end{array}$ & $\begin{array}{l}3.3 \\
6.0 \\
4.9 \\
4.8 \\
4.7 \\
6.8 \\
5.9 \\
5.9 \\
7.2 \\
6.2 \\
6.5 \\
6.2 \\
5.5\end{array}$ & $\begin{array}{r}8.5 \\
12.7 \\
12.0 \\
13.2 \\
12.6 \\
16.6 \\
14.4 \\
15.4 \\
18.3 \\
16.8 \\
20.3 \\
18.8 \\
17.2\end{array}$ & $\begin{array}{r}6.4 \\
10.5 \\
9.1 \\
9.9 \\
9.4 \\
12.9 \\
12.9 \\
13.0 \\
15.1 \\
13.5 \\
15.2 \\
15.1 \\
14.8\end{array}$ & $\begin{array}{l}4.3 \\
7.3 \\
6.1 \\
6.3 \\
6.0 \\
8.9 \\
8.1 \\
8.3 \\
9.8 \\
9.1 \\
8.9 \\
8.6 \\
7.3\end{array}$ & $\begin{array}{l}3.4 \\
6.6 \\
5.3 \\
4.8 \\
5.3 \\
7.3 \\
5.9 \\
6.3 \\
7.3 \\
6.5 \\
6.9 \\
6.3 \\
5.5\end{array}$ & $\begin{array}{l}2.5 \\
5.3 \\
4.0 \\
3.9 \\
3.8 \\
6.2 \\
5.1 \\
4.8 \\
6.3 \\
5.2 \\
5.1 \\
5.0 \\
4.6\end{array}$ & $\begin{array}{l}2.3 \\
4.6 \\
3.6 \\
3.6 \\
3.2 \\
4.9 \\
4.2 \\
4.2 \\
5.1 \\
4.1 \\
4.2 \\
3.9 \\
3.2\end{array}$ & $\begin{array}{l}2.5 \\
4.6 \\
3.8 \\
3.6 \\
3.0 \\
4.5 \\
4.1 \\
3.4 \\
4.5 \\
3.5 \\
3.6 \\
3.5 \\
2.8\end{array}$ & $\begin{array}{l}1.4 \\
3.0 \\
2.3 \\
2.3 \\
3.4 \\
3.8 \\
2.8 \\
2.8 \\
3.9 \\
4.1 \\
3.2 \\
3.4 \\
2.8\end{array}$ \\
\hline
\end{tabular}

Source: 1974 Manpower Report of the president, (Washington, D.C.: U.S. Government Printing Office, 1974), p. 271 and 272 . 
by either Party, but a number of specific measures were considered. The Democrats were spectacularly successful in the 1958 election, gaining a total of thirteen seats in the Senate and forty-seven in the House. All analyses of the 1958 election, including Eisenhower's own, rate unemployment 19 and the recession as the major factors. After a twelveyear hiatus, the issue of unemployment again became a high priority on the federal government agenda.

A Senate Special Committee on Unemployment Problems was appointed in 1959, and its hearings and report were important in rebuilding the consensus against unemployment among both Republicans and Democrats. The hearings revealed that full recovery from the 1957-58 recession was slow in coming. Production did rise in the last half of 1959, but employment did not rise correspondingly. Unemployment averaged 5.5 percent throughout 1959. It was particularly high in certain geographical areas and among older workers. Although the economy in the $1950^{\prime}$ 's had recovered after each recession, after each recovery a larger residue of unemployment remained. New terms such as automation, structural unemployment, and mechanization crept into the vocabulary, and gradually were perceived as public issues. The senate Special Committee's recommendations, which included an area redevelopment program, retraining programs, and a Youth Conservation Corps, were to become the agenda for manpower legislation in the early 1960's. 
THE EMERGENCE OF MANPOWER PROGRAMS

Positive Manpower Policy Support Cycle

By 1960 manpower policy, which is a subcategory of employment policy, had entered into a positive policy support cycle which has continued up to the present time. The beginning of the cycle occurred in the late 1950's with the identification of structural unemployment as a public problem requiring government intervention. The supporters of a depressed areas bill, which was vetoed by President Eisenhower in 1958 and again in 1959, had attracted public attention to the problems of depressed geographical areas and had formulated a plan for intervention which had received the support of the Congressional majority. The Senate Special Committee on Unemployment Problems identified additional problems caused by structural unemployment. By 1961 high priority was given to these problems by both the Congress and the Administration.

Charles 0 . Jones in Introduction to the Study of Public Policy presents a policy-making model which approximates the policy cycle in manpower policy from 1961 to the present. (See Figure 1) 


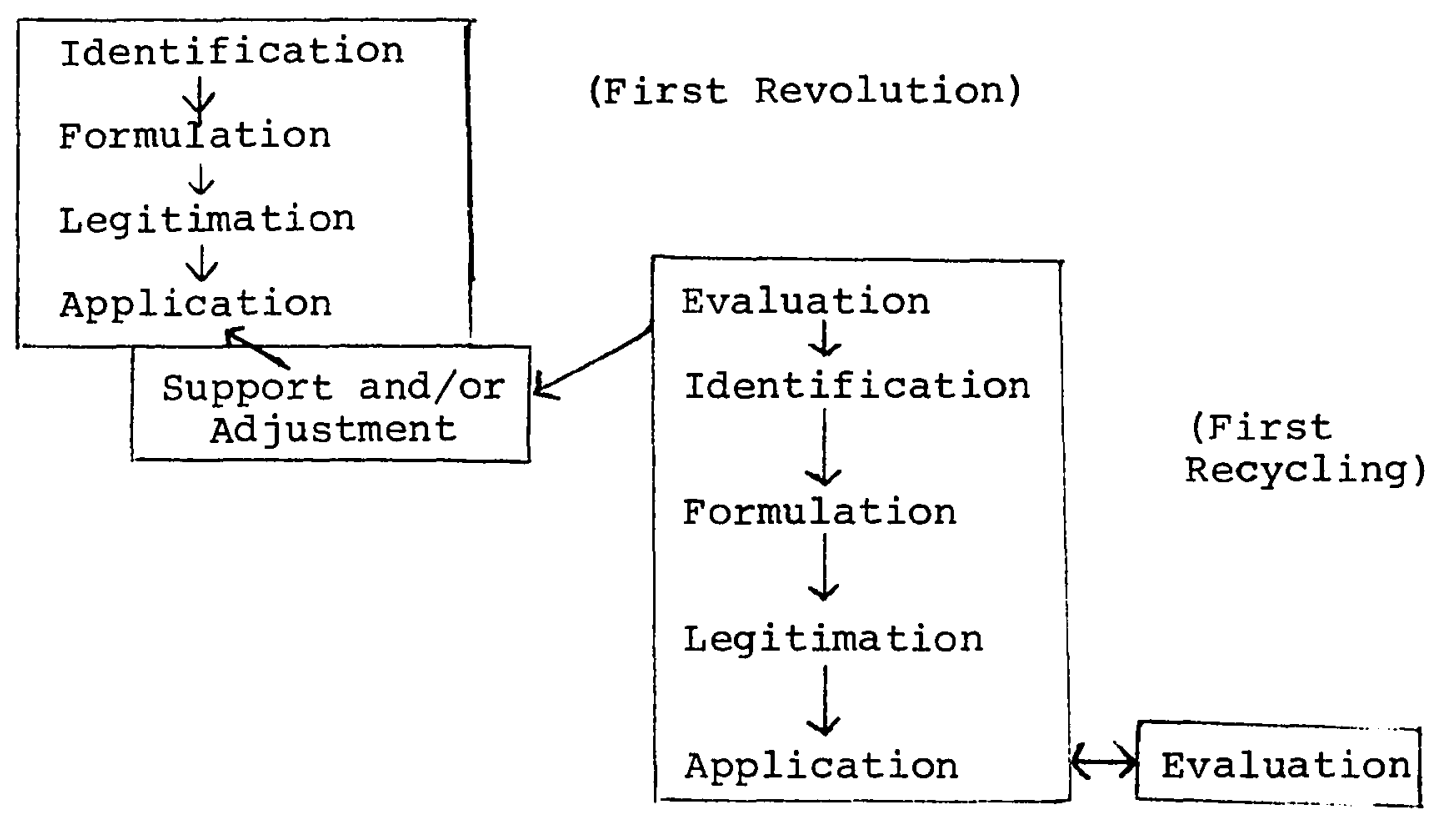

(Second and Subsequent Revolutions)

Figure 1. The policy-making cycle

The public policy-making process at the national level is very complex, and the manpower policy-making process is not an exception. A simple process by which a clearly defined problem was solved through a single legislative act cannot be identified. The pluralistic multinucleated structure of policy making involves vast networks of specialized groups linked together in intertwining "decision chains". To enact a policy or change a program requires multiple consent and the need for coalition building. ${ }^{21}$ Compromises necessary to avoid political deadlock may shift the focus of the legislation, fragment its administration through different agencies, or change the legislation to such an extent that the connection between the original conception of the 
bill and its operation in the field is difficult to trace. The national public policy-making process is inexact, incremental, and difficult to chronicle in an easily understood way.

In the area of manpower policy-making many different actors were involved in the complex process from the initial stage of problem identification through evaluation and reformulation. Initial legislation in 1961 was intended to benefit primarily the adult, experienced worker who had been displaced by advancing technology or residence in a depressed geographical area. The legislation was intended to intervene in narrowly defined problems of structural unemployment. As the policy advanced through several cycles, the Congressional definition of the problem widened. The new perceptions and definitions of the manpower "problem" emerged from the experience gained in previous policy cycles. Manpower policy was then reformulated or amended to increase its effectiveness in intervening in the newly identified problem areas.

The input into the Congressional policy process came from the Administration, agencies administering the legislated programs, testimony from experts in the involved areas, officials from other governmental levels, and the beneficiaries of the program. Each participart in the process attempted to lobby Congress and receive majority 
support for their position. Lobbying by agencies administering or desirous of administering the programs was particularly intense and often influenced final legislation. Passage of related legislation, changes in fiscal policy, and all public and private actions affecting employment had an impact on manpower policy. New legislation was constantly being introduced and old legislation amended in an attempt to meet the needs of a constantly changing political and economic environment. But, throughout the period from 1960 to 1974, there existed continuing support for the manpower policy goals of training the unemployed and placing them in jobs. Evaluations and feedback indicated that at least in the short run the policy was realizing these goals.

Economic Policy

The Kennedy slogan of "Get America Moving Again" indicated the return to the political forefront of economic and unemployment issues. In the winter of 1961 the unemployment rate had reached a postwar peak of 8.1 percent (unadjusted for seasonality). But the political consensus was divided on the question of appropriate fiscal policy. The slack economy received high priority attention, but radical innovations in fiscal policy were not politically feasible in 1961. As Charles E. Iindblom postulated in The Policy Making Process, the more different an alternative is from past policy, in this case an unprecedented tax cut in a 
sluggish economy, the more unpredictable the outcome and the more difficult it is to recruit support. Policy-makers acted as predicted in Lindblom's "Incremental Change Model", and neither the Administration nor the Congress were willing in 1961 to adopt innovative policy. Instead, the search for alternatives covered only alternatives incrementally different from past policies and formulation of new legislation in 1961 was developed from those alternatives. The programs aimed at structural unemployment had precedents and were politically acceptable.

The passage of the Tax Cut of 1964 should chronologically be located later in this chapter. I include it here so as not to intrude the discussion of fiscal policy into the material on social legislation. For ten years following the Korean War, the economic policies of fiscal orthodoxy had been tested. The results had been three recessions, a slow rate of economic growth and chronic unemployment. President Kennedy, sensitive to Republican charges of fiscal irresponsibility, attempted to maintain a balanced budget for his first two years in office. But, in 1962 with unemployment still averaging 5.5 percent in a slack economy, Kennedy launched a public education campaign on the "New Keynesian Economics" primarily aimed at Congress. The key actors in the campaign for the tax cut were Keynesian economists, the leaders of the nation's business community - 
including the U.S. Chamber of Commerce - and the Administration. The support of Wilbur Mills, Congressional Representative from Arkansas and the Chairman of the powerful House Ways and Means Committee, was crucial to its passage. After months of sharp debate the tax cut became law in February 1964. The deliberate tax cut to increase aggregate demand and expand the economy was successful and marked the beginning of a new era in fiscal policy. The economy experienced rapid growth and unemployment dropped from 5.2 percent in 1964 to 4.5 percent in 1965, despite the accelerating rate of labor market growth.

The tax cut had an important impact on related manpower and social welfare programs. The sharp debate had focused public and Congressional attention on the high unemployment rates among the disadvantaged. The success of the tax cut supported a theoretical rationale for increased government spending to spur the economy which led to a favorable Congressional climate for new legislation.

\section{STRUCTURAL UNEMPLOYMENT: THE DEVELOPMENT OF MANPOWER POLICY}

In 1961 the first piece of legislation aimed at the problems of structural unemployment was signed into law. The Area Redevelopment Act (ARA) did not fulfill the hopes which accompanied its passage. It failed to make a significant impact on unemployment nationally or in target areas. 
New industries operating in a sluggish economy were not attracted to depressed communities by low interest loans, small scale training programs, and new public facilities. However, the lessons learned under the ARA were applied in the Economic Development Administration created in 1965.

The Manpower Development and Training Act

The Manpower Development and Training Act of 1962 was the major piece of manpower legislation passed during the 1960's. Its passage and subsequent amendments provide a good example of the operation of the Congressional manpower policy making system during the 1960's.

By 1961 bipartisan support for a broad training program on a national level had developed. General agreement existed between the Administration and Congress that national intervention was necessary to combat structural unemployment among adult, experienced workers. The proposed training program was not a radical innovation, and it attracted support from fiscal conservatives as well as expansionists. The conservatives' support siemmed from their position that nothing was basically wrong with the economy and stimulation was not necessary. High unemployment rates were due to technological change which had displaced large numbers of workers. The upgrading of skills would reduce the unemployment rate as the workers filled available jobs. For fiscal expansionists training was viewed as a necessary supplement 
to increasing aggregate demand through monetary and fiscal policy. Thus, the program gained support for different theoretical reasons. On the more political level both Senators and Representatives recognized that retraining programs offered direct aid to constituents. A Gallup poll showed 67 percent of the people "willing to sacrifice" to 23 pay for retraining the unemployed. Retraining was endorsed by a national consensus, the necessary majority was assured, and Congress began debate on the nature of the program.

The central issue in the ensuing debate was which federal agency should have control over the new program. A large scale training program would mean funds and power for the administrating agency. The question of who should administer a new program invariably brings new actors into the Congressional policy making process, each lobbying for his own interests and attempting to persuade key Congressmen to include their agency in the legislation. In this case the battle for control was between the existing federal-state vocational education program under the Department of Health Education and Welfare (HEW) and the Department of Labor (DOL). Critics of the vocational education program charged that the program, which at that time was predominantly oriented to training in home economics and agriculture, was too far out of touch with the modern labor market to be useful. The Bureau of the Budget strongly supported this 
opinion and attempted to have the program placed in the DOL and run as a direct federally funded and controlled program using the facilities that the DOL selected. Due to the lobbying pressure of the powerful American Vocational Association, the responsibilities were ultimately divided between HEW and DOL. The uneasy compromise officially resolved the issue of control. But, the interagency conflict continued and had a long term impact on the manpower delivery system.

The basic features of this important manpower legislation were: "(1) Full federal financing for the first two years, followed by continued federal support for on-the-job training but providing only fifty percent matching funds for institutional training of the unemployed in occupations with reasonable expectations of employment; (2) Heads of families with at least three years of working experience could qualify for up to fifty-two weeks of training allowances at levels equal to average unemployment compensation benefit in the state; (3) Limited number of youths aged nineteen to twentyone years could receive training allowances of twenty dollars a week; (4) Title I required an annual Manpower Report by the President and the DOL was authorized manpower research and development funds." The legislation was aimed almost exclusively at the adult, displaced, experienced worker. 
When the first debates over the MDTA began in 1961, the unemployment rate among married men averaged 4.6 percent and the rate for white males from ages 25 through 65 was approximately 4.7 percent. 25 The assumption of many of the sponsors of MDTA was that many of these and other experienced workers had been displaced by advancing technology, Government sponsored retraining was necessary to assist these workers in finding new positions. But, as the economy recovered, those workers who theoretically had been displaced by automation found employment without government assistance. By 1963 the unemployment rate for married men had fallen to 3.4 percent and the figure for white males between the ages of 25-65 was approximately 3.6 percent. Once the MDTA was in operation it became apparent that the enrollees were not the target group envisioned by the policy-makers. The enrollees were increasingly what has since been termed the "hard core" unemployed - youth, minorities, illiterates, and aged workers. The enrollees did not meet the assumed basic literacy levels expected by the program designers. The clients, in the opinion of those administering and monitoring the program, required much longer training programs including basic education to prepare them for employment. The youth allowances, which were Iimited under the Act to five percent of expenditures were inadequate when 25 percent of the MDTA enrollees were 
youths. Agencies involved in the program returned to congress to obtain amendments which were necessary to meet the demands of the disadvantaged client population. Neither the Congress nor the involved agencies appeared to seriously consider alternative program models which might serve this newly identified target population more effectively. The MDTA program had attained momentum and had developed constituent agencies and groups concerned with its continuation. MDTA amendments to accommodate the needs of the disadvantaged clientele were passed almost unanimously by Congress in 1963.

By 1965 the MDTA had taken a significant step away from being a temporary program to aid adult displaced workers towards becoming a permanent remedial program to alleviate serious inequalities in the competition for jobs. Congress had assumed a national responsibility for attempting to raise the incomes and increase the employability of the disadvantaged portion of the population. It was assumed that providing basic education, skills training, and placement services would aid the disadvantaged population in reaching these goals. MDTA amendments in 1965, 1966, and 1967, broadening the scope of the program and increasing expenditures, received almost unamimous bipartisan support.

The Era of Social Engineering

The MDTA was one of a series of legislative acts which 
received Administration and Congressional endorsements during the decade of the 1960's. An unprecedented number of programs purporting to "solve" the social and economic inequities of American society were passed under the rhetoric of Kennedy's New Frontier and Johnson's Great Society. Many of the programs were aimed at the disadvantaged population. The theoretical framework for the legislative programs was derived primaxily from empirically untested assumptions developed in the social sciences. "Underlying most of the theories was the belief in 'environmentalism' - the assumption that man is almost Iimitlessly malleable: through manipulating the external conditions of living, it should in principle be possible to secure almost any desired behavior and any level of achievement." 28 This almost unquestioning belief in environmental determinism and the equality of all persons if given equal opportunities is a general theme which runs through the social welfare legislation, including manpower legislation, adopted during the 1960's. The reformers postulated that government intervention could effectively alter individual behavior. They were overly optimistic about the U.S. policy making process and the effectiveness with which government programs can intervene in a clear cut fashion in the structure of a highly complex society. The promises and slogans surrounding the legislation raised popular expectations to unrealistic levels. 
The plethora of social intervention legislation included many programs expected to have an impact on the employment rates and income levels of the disadvantaged. Experience gained under the early years of the MDTA helped in formulating the new legislation. Recognition of institutional barriers to employment and a widespread reaction to discrimination, resulted in the 1964 Civil Rights Act which forbid discrimination in employment on the part of all private employers with more than a minimal number of workers. Recognition that more than prejudice stood between the disadvantaged and satisfactory jobs was illustrated in the emphasis of the Economic Opportunity Act of 1964. The one billion dollar "War on Poverty" created the Job Corps and the Neighborhood Youth Corps for providing youth with training and remedial education; the work study program to assist college students; one hundred percent federal financing for training programs for welfare recipients; and loans to small businesses. The legislation was the combination of one new idea - the Community Action Agency (CAA) made up of local citizens which would administer and plan the programs - and long discussed programs designed to "help the poor help themselves". The manpower programs included in the bill were aimed at either employing or training the employable poor, particularly the youth. The legislation was a "foot in the door" for advocates of public service employment. 
In 1965 the consensus against unemployment, poverty, and discrimination was at its height. Advocates for manpower programs found a warm reception. But, by 1966 unemployment had reached a thirteen year low of 3.8 percent, and the continued escalation in Vietnam provided a drain on federal dollars. Inflation was threatening, and pressure to decrease federal spending was developing. Traditionally, the combination of low unemployment and inflation would have signalled a withdrawal of interest in manpower issues. But, once policy cycles have developed in a particular issue area, stopping the process is a major assignment. By 1967 criticisms of the operations of manpower and poverty legislation were steadily increasing, but too many commitments by too many people existed at that point for termination of programs to occur. A constituency existed which was created by earlier manpower and poverty legislation and which had a vested interest in their continuation.

Bureaus, Congressional committees, and lobbyists populate the policy-making systems. Termination of a particular pattern is almost never a clean break, but a gradual shifting of functions. The initial shifting in the manpower area was characterized by attempts on the part of involved agencies to create administrative order out of the maze of existing programs.

Administrative Reform

By 1967 the manpower system encompassed seventeen major 
programs and thousands of separate contracts. Each of the programs in operation had different eligibility rules, allocation formulas and application procedures. The Department of Health Education and Welfare, the Dffice of Economic Opportunity, and to a minor degree the Departments of Agriculture and the Interior were all active in the manpower field. The confusion created by conflicts between the administering agencies was heightened by intra-agency competition between the three separate bureaus responsible for manpower under the Department of Labor. At the lower levels of government the federal conflicts and the lack of coordination between programs serving the same target group contributed to almost chaotic conditions. Local power struggles interjected an even greater level of confusion into the system. ${ }^{30}$ Federal administrators recognized the need for administrative reform.

Gradually, as manpower control was consolidated at the federal level under the DOL and HEW, several important attempts were made to improve planning, coordination, and administration at the local level. Two of the attempts are discussed in the following material.

Ghetto riots had placed a high priority on intervention in the employment problems of inner-city residents. A major attempt to meet these needs was launched with the creation of the Concentrated Employment Program (CEP) in 1967. The program was designed to concentrate manpower 
funds on targeted high unemployment areas. A central administrative unit was to coordinate the existing programs and provide one-stop, individualized manpower services to the ghetto unemployed. Experience in other programs attempting to train the hard core unemployed indicated that a straight on-the-job setting was not enough. The disadvantaged population often had multiple problems, such as poor health, child care needs, etc., which interfered with their ability to perform on the job. The CEP program, modeled after the new Chicago YMCA's "Jobs Now", provided for orientation to the world of work, counselling, medical and social services, and individual job coaches to follow the participant from enrollment through job placement. Administratively, the concept of the program was a step forward. But, jurisdictional conflict between OEO and the DOL created service delivery problems before the program began operation. Furthermore, CEP never gained the intended control of MDTA Institutional funds and the NABS-Jobs program. Expansion from the original twenty-two areas to eighty-two areas diluted available funds and decreased effectiveness. CEP was unsuccessful as a coordinating agent and became one more local program among many.

The second attempt to bring order into the chaos of the local manpower system was the establishment of the Cooperative Area Manpower Planning System (CAMPS). CAMPS was initially envisioned as a method to bring the state 
governments into the delivery system with the possibility of eventually funneling manpower funds through the states to the localities. State committees were to create a comprehensive manpower plan by consolidating local CAMPS plans and bringing unity to a disjointed system. Unfortunately, most governors failed to appreciate the possibilities, and the majority of state plans were simply a collection of local plans, which in turn were a collection of separate programs. CAMPS lacked any direct control over funding, and thus lacked any real power in the manpower system. CAMPS failed to perform as anticipated, but it did create a means of communication between groups and individuals concerned with manpower. It also provided preliminary manpower planning experience at the lower levels of government. Both the CEP and the CAMPS programs were to provide important experience and models for new legislation in the 1970's.

By 1969 the Administration and Congress were aware of the need for reorganizing the manpower delivery system. National administration of the programs did not appear to be workable. Under the American system policy decisions are often made by the agencies charged under legislative acts with administering the legislation. The administration of manpower policy, divided between powerful departments, provides an example how administrative policy making can greatly impair the effectiveness of legislated policy. The attempts at coordinating the various programs into a unified 
whole were doomed to failure due to underlying agency conflicts. Successful coordination demands that all involved agencies have the same substantive interests, presumably in this case serving the target population in the best possible fashion. But, it appears that the primary interest of the bureaucracies concerned was often to maintain or increase their own authority. Serving the best interest of the intended beneficiaries was secondary to their own survival and/or growth.

Members of Congress are well aware of the problems created when competing agencies are involved in the administration of one issue area. But, powerful agencies such as those involved with manpower have influential Congressional lobbies which often prevail during the formulation of legislation. The power of the agencies also contributes to the difficulties encountered in reforming poorly functioning delivery systems.

Congress is also slow to deal with administrative problems because such matters generally lack public visibility. Officials prefer to focus on programs which have easily identifiable benefits for their constituents and broad political appeal. In the manpower area, strong pressure from the Administration was necessary before Congress acted on the reorganization of the delivery system. For approximately four years from 1969-1972 manpower reform was an underlying issue in a battle between a Republican President 
and a Democrat dominated Congress over public service employment.

\section{Public Service Employment}

The notion of the government as "the employer of last resort" grew in popularity throughout the 1960's. Americans, who have always placed a positive value on work for income received, appeared to favor public service jobs over transfer payments. A national Gallup poll in the late $1960^{\prime} \mathrm{s}$ found 80 percent willing to guarantee job opportunities and an equal percentage opposed to guaranteed incomes. Creation of limited numbers of public service jobs had been written into a number of programs. By 1969 the creation of a large-scale public service job program had become a major concern of such groups as the AFL-CIO, the Urban Coalition, and the League of Cities-U.S. Conference of Mayors. Several commissions, such as the Kerner Commission, and task forces had also recommended public sector job creation.

The Employment and Training opportunities Act introduced in May, 1969 was a multibillion dollar public service employment program. The Nixon Administration and particularly Secretary of Labor Schultz, who had opposed public sector job creation on the grounds that fiscal and monetary policy combined with limited training-linked jobs would curb 33

cyclical unemployment, were forced by the strength of Senate support to commit themselves to public service jobs 
in exchange for the introduction of a series of amendments aimed at tightening, but not eliminating, the program. One amendment was adopted, and the bill passed the Senate 68-6 in 1970. In the House, where the Administration had more support, Malcolm Lovell, Assistant Secretary of the Department of Labor, bargained more successfully. In an all night session Lovell with leading Democrats and Republicans from the House Select Labor subcommittee, produced a new manpower bill, retaining a major section on public service jobs, but also including large-scale manpower reorganization, decentralization, and decategorization which were priority aims of the Administration. The House passed the bill after vigorous debate in late 1970.

The House-Senate Conference on the bill marked the breakup of the bipartisan support which had backed manpower legislation for nearly a decade. The senate position on public service employment which prevailed in the conference created what could have become a permanent large scale program. The issue of public sector job creation which divided the conference was fundamentally an ideological one which had separated conservatives and liberals, Democrats and Republicans for decades. It was a question which had mainly been avoided under previous manpower legislation. Although Republicans were willing to compromise to the extent of supporting temporary public service jobs, massive permanent programs were not fundamentally acceptable. Politically 
realistic, they voted for the bill while privately urging a presidential veto. On December 16, 1970 President Nixon vetoed the Conference bill which had narrowly passed the House. The Senate failed to override the veto. The intensive debate over public service jobs overshadowed the question of manpower service delivery system reform. But, the hearings on the bill marked the first overall Congresssional assessment of the manpower programs of the 1960's, and the first major attempt at change since the MDTA and the EOA. The delivery of services had received explicit attention and the appropriate functions of the federal, state and local government had been seriously considered. The fundamental need for change was recognized in Congress, but continued to be a low priority among the majority. Facing a 5.9 percent unemployment rate in 1971, the Congressional majority considered public employment, an issue with high public visibility and immediate benefits, as a high priority.

The sponsors of public service employment in Congress persisted and introduced the Emergency Employment Act of 1971. The bill authorized the Secretary of Labor to contract with lower levels of government to create public service jobs. Shrewdly written to avoid a presidential veto the act was to be operative for only two years. It was also a step towards revenue sharing in that mayors and governors were given broad powers in selecting jobs and participants 
and in operating local programs. For pragmatic political reasons, it was difficult for President Nixon to veto a transitional public service employment bill with wide public support. The White House supported the bill in exchange for Congressional promises to move quickly on comprehensive manpower reform, preferably manpower revenue sharing.

\section{Manpower Revenue Sharing}

The Congressional hearings in 1969 and 1970 had exposed the need for a general overhaul of manpower programs. Most analysts agreed that the objective should be similar to the CEP model - a centralized, easily accessible, administrative unit where a client needing manpower services could go and receive individualized help from the initial counselling to the final job placement. The local agency would have access to information about the needs of the local labor market and developed contacts for job placement. Local manpower plans should be drawn up by a representative decisionmaking body. The plans should be realistic and allow for flexible response to changing clientele and the local labor market.

The Nixon Administration's position was that these objectives could best be met by manpower revenue sharing. In keeping with this goal was the desire to eliminate the existing maze of categorical programs with their rigid funding and eligibility requirements. Federally managed categorical programs, while in many ways commendable, were by 
their nature not sensitive to local needs. Decentralization of manpower planning, design, and operation responsibilities was considered desirable by the Administration, to allow local and state governments to decide for themselves the types of manpower services required in their area. The Administration argued that state and local units, being closer to their problems, would be able to act more quickly and efficiently in supplying effective manpower services. Program guidelines and goals originating in Washington, D.C. could not possibly foresee the varied situations with which the localities must contend.

In 1971 President Nixon had submitted the proposed Manpower Revenue Sharing Act of 1971 to the Congress, but Congressional resistance to revenue sharing, as well as other considerations, prevented its passage. During 1973, the Administration stepped up decentralization and decategorization of manpower programs through administrative means, and threatened Congress that manpower revenue sharing would be implemented by executive fiat in 1974 regardless of whether Congress acted on or rejected the concept. Continuing pressure was put on Congress to pass a compre37 hensive reform manpower bill. On December 28, 1973 President Nixon signed into law the Comprehensive Employment and Training Act of 1973 (CETA), the first legislation to incorporate the essential principles of special revenue sharing. 
CETA largely eliminates categorical programs authorized under previous legislation. Instead, the Secretary of Labor is authorized to make block grants to about 500 local and state and general government units with populations of 100,000 or more who will act as prime sponsors for their areas. The prime sponsors are expected to plan and operate manpower programs to meet local needs with little federal direction or interference. Specific provision for the transitional period through fiscal 1974 was included in the legislation.

The basic features of this important new legislation are as follows: (1) state and local prime sponsors are to receive 80 percent of the authorized Title I CETA funds to provide comprehensive manpower services in their areas. One percent of this allocation is to be available for staffing and serving State Manpower Services Councils which will review state and local manpower plans, monitor their operations and make annual reports to the government. The remainder of the funds is to be used by the prime sponsors. They are authorized, but not limited to, using the funds to provide recruitment; orientation; counselling; testing; job placement; subsidized on-the-job training; trainee allowances; supportive services; and transitional public employment programs. Individuals may not receive training allowances for more than two consecutive years, as the intent is to provide training for permanent private employment and not 
long-term public support. The public service employment program must be fully integrated with the comprehensive manpower services. A representative Planning Council to plan, monitor, and evaluate manpower efforts in light of local needs is to be appointed by the prime sponsor. of the remaining twenty percent of Title I money, five percent is available to encourage combinations of local government units to serve as prime sponsors; five percent is available for grants to provide needed vocational education services; four percent is to help states make comprehensive plans and to coordinate services; and the remaining funds are to be used at the discretion of the Secretary of Labor. (2) Title II provides for a transitional public service employment program in areas with 6.5 percent unemployment rates for more than three consecutive months. Persons unemployed for more than thirty days are eligible. Priority is to go to unemployed veterans who served in Korea or Vietnam after August 4, 1964 and to the most severely disadvantaged. Under Title III the Secretary of Labor is authorized to provide federal supervision of manpower programs for Indians and migrant and seasonal farmworkers; and for special target groups such as youth, older workers, and others with particular labor market disadvantages. The Secretary of Labor is also to undertake research, experimental and demonstration programs, evaluations of all programs, the development of a labor market information system, and a computerized job 
placement program. (4) Title III grants the secretary responsibility for operation of the Job Corps. (5) Title.V creates a National Commission for Manpower Policy to identify national manpower goals, prepare an annual report to the President and Congress, examine the effectiveness of manpower programs, and evaluate and make recommendations to the Congress on the impact of the energy shortage upon 38 manpower needs.

\section{SUMMARY}

The passage of the Comprehensive Employment and Training Act of 1973 marked the beginning of a major new approach to the delivery of manpower services. In the 1960's manpower policy had received bipartisan support at the federal level. Programs had multiplied as national leaders attempted to develop a manpower policy which would deal with the emerging problems. Concomitant with this development, serious problems had arisen - a proliferation of separate categorical programs; excessive duplication of delivery systems; and overcentralization at the national level. For four years a general consensus existed in Congress that reform was necessary, but it took that four years to develop a majority consensus on the substance of the reform. With the passage of CETA Congress essentially turned over the planning and operation of manpower programs from the national 
to the state and local levels of government. Federal supervision and funding included in the legislation insured that national purposes would be carried out, but the responsibilities for planning, designing, and implementing the programs passed to the lower levels of government. 
10. Robert Aaron Gordon, The Goal of Full Employment (New York: John Wiley and Sons, Inc., 1967), p. 43.

11. Ibid., p. 45 .

12. John Dewey, The Public and Its Problems (Chicago: Gateway Books, 1946).

13. Charles E. Lindblom, The Policy Making Process (Englewood Cliffs, N.J.: Prentice Hall, 1968).

14. U.S. Congress, Senate, Subcommittee on Employment and Manpower of the Committee on Labor and Public Welfare. United States Senate, Toward Full Employment: Proposals for a Comprehensive Employment and Manpower Policy in the United States, $88 \mathrm{th}$ Cong., 2nd Sess., 1964, p. 7 .

15. Robert Gordon, p. 45.

16. Garth Mangum, The Emergence of Manpower Policy, p. 16 .

17. U.S. Congress, Senate, Subcommittee on Employment and Manpower of the Committee on Labor and Public Welfare. United States Senate, Toward Full Fmployment: Proposals for a Comprehensive Employment and Manpower Policy in the United States, 88 th Cong., 2nd Sess., 1964, p. 8 .

18. Legislative History of the Employment Act of 1946 is detailed in Stephen K. Bailey's Congress Makes A Law (New York: Columbia University Press, 1950).

19. James L. Sundquist, Politics and Policy: The Eisenhower, Kennedy and Johnson Years (Washington, D.C.: Brookings Institution, 1968) p. 28 .

20. U.S. Congress, Senate, Subcommittee on Fmployment and Manpower of the Committee on Labor and Public Welfare. United States Senate, Toward Full Employment: Proposals for a Comprehensive Employment and Manpower Policy in the United States, 88th Cong., 2nd Sess., 1964, p. 9. 
FOOTNOTES - CHAPTER II (Continued)

21. Dennis A. Rondinelli, "Urban Planning as Policy Analysis: Management of Urban Change", American Institute of Planners Journal, January 1973, Volume 39, Number 1, p. 20.

22. For a full history of the Area Redevelopment Act, see Sar A. Levitan, Federal Aid to Depressed Areas (Baltimore: Johns Hopkins Press, 1964).

23. James Sundquist, p. 86 .

24. Garth L. Mangum, MDTA: Foundation of Federal Manpower Policy (Baltimore: Johns Hopkins Press, 1968) p. 19.

25. 1974 Manpower Report of the President (Washington, D.C.: U.S. Government Printing Office, 1974), pages 277 and 273 .

26. Ibid.

27. Garth I. Mangum, MDTA, p. 26.

28. Tom Alexander, "Social Engineers Retreat Under Fire", Fortune, October 1972, p. 134.

29. Garth L. Mangum, The Emergence of Manpower Policy, p. 235 .

30. Sar Levitan and Robert Taggert III, Social Experimentation and Manpower Policy, p. 64 .

31. Roger Davidson, p. 56.

32. Ibid., p. 31 .

33. Ibid., p. 32 .

34. Sar A. Levitan and Robert Taggert, ed. The Emergency Employment Act: The PEP Generation TSalt Lake City: Olympus Publishing Co., 1974), p. 12 .

35. Roger Davidson, p. 102 .

36. U.S. Congress, House of Representatives, Committee on Education and Labor, Manpower Development and Training Act Extension, June 18, 1973: Report Together With Minority, Additional, and Dissenting Views, 93rd Cong., Ist Sess., 1973, p. 4 . 
FOOTNOTES - CHAPTER II (Continued)

37. The MDTA and the Emergency Employment Act of 1971 expired at the end of fiscal 1973.

38. 1974 Manpower Report of the President, p. 193-242. 
CHAPTER III

THE COMPREHENSIVE EMPLOYMENT AND TRAINING ACT: DECENTRALIZATION, DECATEGORIZATION AND THE DISADVANTAGED

The passage of the Comprenensive Employment and Training Act of 1973 (CETA) reflected the changing perceptions concerning social intervention strategies for government programs. The initial enthusiasm for large federally controlled social programs had declined throughout the country as both supporters and critics grew disillusioned with the programs' high costs and questionable effectiveness. Waste, duplication, and inefficiency in the operation of social programs created a visible target for public complaint. The experience of the Vietnam War had generated a growing distrust of the federal government. The idea of local control of social programs gained popularity. President Nixon's support for revenue sharing coincided with the need for manpower reform and the decategorization of manpower programs. CETA was based on practicality and American political ideology which enshrines the value of local control. Congress turned manpower over to the lower levels of government on the assumption that local officials would know best what their local areas required and would respond more quickly and effectively to the needs of their citizenry. 
In December 1973 when CETA became law, the national unemployment rate was 4.5 percent. Titles I through IV which authorize operating programs were intended to effect structural unemployment. The disadvantaged, who make up a high percent of the unemployed during times of low unemployment, were the intended beneficiaries - although the terms unemployed and underemployed appear often in the actual legislation. By 1974, when local prime sponsors had barely begun implementation of Title I programs, the national unemployment rate had passed seven percent and was still climbing. In some localities unemployment rates were above eight percent. 39 The need for countercyclical programs appeared urgent, and the Emergency Jobs and Unemployment Assistance Act of 1974 (EJUAA) was quickly passed into law in December 1974. It became Title VI of CETA and authorized 2.5 billion dollars for public service jobs to be administered by CETA prime sponsors. Shortly afterwards an additional 473 million was added for summer youth programs to be administered through CETA channels. Categorical programs to meet national priorities were again acceptable to the Congressional majority.

The federal addition of two well-funded categorical programs raises several major questions about CETA. CETA, which accounts for only fifty-six percent of federal manpower program funds, was intended originally to act against structural unemployment problems through decategorized, 
decentralized manpower programs. But, Title VI and the summer youth program are categorical programs aimed at cyclical unemployment. These programs, which undermine the intent of CETA, were nevertheless passed by the federal government to be administered through the CETA system. If this trend continues the CETA program may become a decentralized delivery system administering categorical programs. As Figure II demonstrates, the "decategorized" funds available to prime sponsors for flexible use - with some shifting between Titles permitted - in fiscal year 1975 make up only 42 percent of the CETA funds authorized, but 89 percent of the CETA funds were administered through the decentralized delivery system. The promised local control may be illusionary. If Congress continues to react to perceived national economic problems by tacking legislation onto CETA, the local prime sponsors will be limited in their flexibility and tied to a rigid manpower system which has shifted responsibilities for delivery of service, but not definition of the problem. Local prime sponsors may become as limited in their capabilities for reaction to local problems as were the federal agencies who previously administered manpower programs. The U.S. Department of Labor's role, which is presently ambiguous, may become increasingly powerful as it reasserts its responsibilities for federal oversight of categorical programs. 
Figure 2. Amounts authorized for program activities under the Comprehensive Employment and Training Act, fiscal year 1975 .

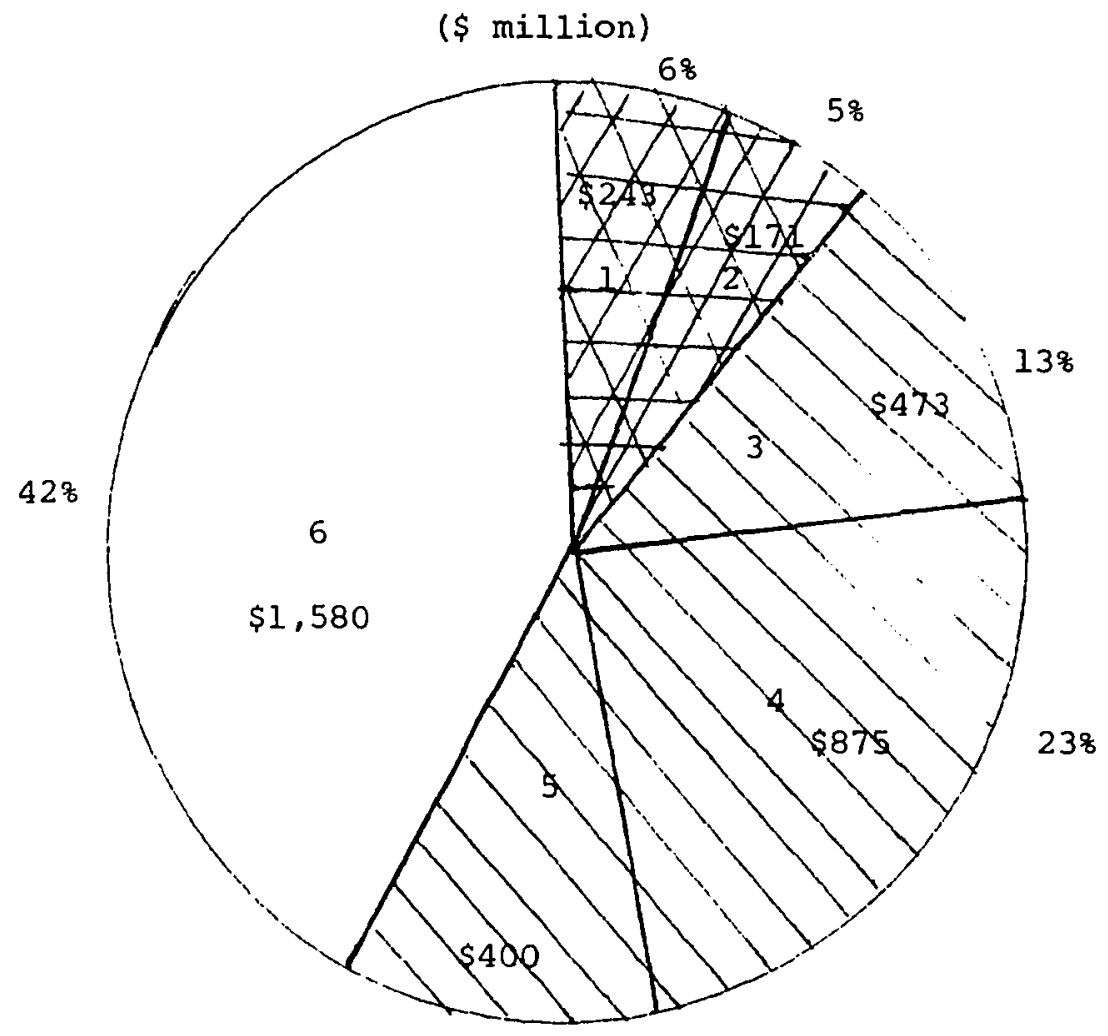

$11 \%$

1. Title III National Programs

2. Title IV Job Corps

3. Title III Summer Youth Programs
4. Title VI Public Employment 5. Title II Public Employment

6. Title I Comprehensive Manpower Programs

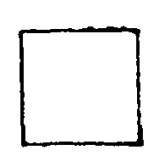

DECATEGORIZED $42 \%$
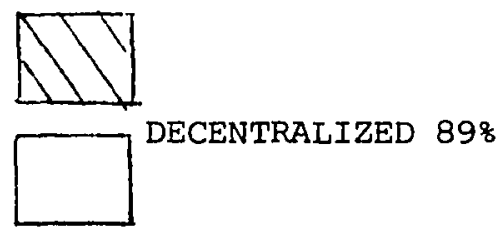

Source: William Muengoff and Lester Rindler, The Comprehensive Employment and Training Act, (Washington,D.C.,National Academy of Sciences, 1976), p.24. 
Serious consideration should be given to the effects of combining programs aimed at structural unemployment with programs aimed at cyclical unemployment. Although both are intended to benefit the unemployed, the disadvantaged unemployed require training programs, counseling, etc. to prepare them for employment. The temporarily unemployed skilled worker has quite different needs, and the inclusion of Title VI under CETA has strained the abilities and resources of prime sponsors attempting to effectively administer CETA programs. Separation of counter-cyclical programs from structural unemployment programs should be considered.

\section{DECENTRALIZATION}

The decentralization and decategorization of manpower programs were expected to result in superior planning and administration of programs while eliminating the overlap, duplication, fragmentation and inefficiency of earlier federal programs. The normal Congressional process of compromise and negotiation preceded the final decision on the definition of prime sponsors under CETA. The desire to designate a prime sponsor covering an entire labor market area was sacrificed for practical and political reasons. Practically, there existed no units of government covering the labor market area in the great majority of localities. The existing units of general government - including states, 
cities, and counties - testified to their abilities and interest in becoming prime sponsors. The final legislation designated general units of local governments with populations of 100,000 or more, consortia of such units, and states as eligible prime sponsors. Funds to induce the formation of consortia, which may have covered a labor market area, were limited to not more than 5 percent of the amount available under Title $I$. The legislation made it possible for many manpower prime sponsors to operate in the same labor market area. The Act created the potential for excessive decentralization with accompanying fragmentation, duplication and inefficiency.

Most of the labor market areas in the U.S. include a number of general units of local government eligible for prime sponsorship under CETA. Lacking strong incentives it is unlikely that a single labor market area will be served by a single prime sponsor operating programs aimed at the total area. Political rivalry, the distrust existing between many suburban or rural governments and city units, and the desire to control manpower funds inhibit the formation of: consortia. The fragmentation of manpower programs by political boundaries rather than program category is likely to result in similar inefficiency, duplication and lack of coordination in the manpower area.

Little is presently known about the economics and diseconomies of scale in manpower programs, but it appears 
likely that at least some functions such as planning, developing labor market information, developing management information systems, and evaluation could be performed more effectively at the labor market area level. For example, in 1973 no system existed for defining or identifying skills shortage occupations at the local level. Sophisticated methodologies and matrices were developed for national and state forecasting, but little usable or reliable information existed for localities. ${ }^{42}$ The cost of such information is high, and it is unlikely that a single prime sponsor would attempt to develop the needed system. Without reliable information systems, much local planning must be based on attempts to break out local data from national or state studies; or, more frequently, to rely on "intuition" or the "feel" of the local labor market. With several local prime sponsors competing for job placements in the same market area, it is possible reliable information on job openings may be closely guarded.

Decentralization in the Portland Metropolitan Area

In the Portland, Oregon Standard Metropolitan Statistical Area (SMSA) there are currently five different CETA prime sponsors operating manpower programs. Multnomah and Washington counties with a combined 1970 population of $332,710^{43}$ excluding the City of Portland, formed a consortium in May 1974. Columbia County, lacking sufficient 
population for eligibility as a prime sponsor, was picked up by the Oregon Balance-of-State plan. Clackamas County with 44

a population of 196,900 became its own prime sponsor. Across the Columbia River in Washington, Clark County, with a 1970 U.S. census population of 128,454 , also became a prime sponsor. The City of Portland, with a population of 372,500 also became a CETA prime sponsor and was the only incorporated city government of sufficient size in the metropolitan area to qualify as a prime sponsor.

Prior to the passage of CETA no significant DOL funded manpower programs were operated by any of the county or city governments. The Portland Metropolitan Steering Committee (PMSC), a local Community Action Agency (CAA), served as the prime sponsor for the largest manpower program in the area, the Concentrated Employment Program (CEP). The Portland Mayor's Manpower Area Planning Council (MAPC) was responsible for planning in the Portland metropolitan area. The City essentially provided the expertise in the manpower field, although the four oregon counties were represented on the MAPC. Little attention was paid to manpower decisions by local elected officials prior to spring 1974, and officials were barely familiar with manpower categorical 46

grants. The City's manpower director, who was responsible for writing manpower plans and was most familiar with manpower programs, had a tendency to hold things close to his chest. 
In 1973 local governments and agencies began planning for implementation of CETA. Negotiations to form a consortium between the City and the four oregon counties began. During this period county officials became increasingly interested in manpower programs and Multnomah County hired a consultant to study current programs. County officials discovered that although federal manpower funds had been budgeted for the counties, no manpower service system had been developed for the counties. This failure was blamed on the city and the manpower director, in particular. The manpower director offended several of the counties' representatives during the negotiations. Multnomah County, which contains the City of Portland, decided to pull out of the consortium and the other counties followed. The U.S. Department of Labor and the state manpower department did not interfere when the consortium negotiations began to break down. The consortium which would have covered the majority of the labor market area fell apart in April, 1974. The primary reason for the collapse of the consortium was the counties' fear of domination by the City of Portland. The Mayor was a young aggressive politician, and county politicians perhaps feared that too many of the manpower dollars would be diverted from the counties to the City under his leadership. Columbia, Washington and Clackamas counties were also concerned that a city dominated consortium would pay inadequate attention to their 
geographically large rural populations. All the counties evidently wished to obtain autonomy for their own programs which they felt association with the City might preclude. The possibility of the City of Portland entering into a consortium with any or all of the concerned counties appears to be a dead issue. Although all involved parties agree that such a consortium would be theoretically ideal, in that it would improve coordination, and eliminate present duplication and fragmentation of manpower services, none of the involved units were considering reopening negotiations in 1975 .

Fragmentation, duplication, inefficiency and lack of coordination between manpower programs may have increased in the Portland metro area under CETA. The five prime sponsors are all offering similar services, based on the model of former federal programs. All feature intake, orientation and assessment $(I, O, \& A)$; counseling; vocational education; institutional training; public and private on-the-job training; public employment programs; supportive services; placement; and follow-up. All utilize a portion of their CETA funds for administrative costs; the development and operation of a Management Information System (MIS); labor market analysis; job development; planning and supervision; and other related activities. No working coordinating mechanism exists between the five prime sponsors. Officials and bureaucrats appear to be unaware of the activities of 
their counterparts in other units of government. Interviews with concerned staff and officials revealed a lack of knowledge and communication between the five prime sponsors, and between the prime sponsors and the state manpower office. The prime sponsors, operating in the same labor market area, appear to be operating independently of each other.

Access to manpower programs in the Portland metropolitan areas has probably improved under CETA. A citizen residing in any part of the metro area is now eligible for manpower programs. Previously only residents of certain geographical areas were eligible. All five prime sponsors operate central offices and field units in areas of high unemployment. Visibility and accessibility do appear to have improved.

\section{DECENTRALIZATION AND THE DISADVANTAGED}

The ideal geographic unit for manpower planning and operation has usually been recognized as an economically integrated labor market area. CETA has in effect broken up planning and operation into smaller units. Without adequate incentives to form consortia, it is likely that other metropolitan areas are undergoing the same experience described in the Portland metro area. Planning and operating programs within political boundaries tends to separate the place of 
work from the place of residence, and may limit access to job opportunities.

The cost of possible fragmentation by political geography might be borne by the intended beneficiaries of CETA, the disadvantaged and particularly the minorities. Central cities are losing their jobs to the suburbs, especially in manufacturing. Inadequate labor demand in areas accessible to ghetto residents contributes to the present occupational structure of disadvantaged workers who are concentrated in service, laboring, and operative occupations. "According to the 1960 census in the fifteen largest metropolitan areas, central cities provided nearly two-thirds of the jobs in their metropolitan area. By census day 1970 the central cities had only 528 of the total metropolitan area jobs. If, as is likely, the rates of change of the last decade have continued, the suburbs at the present time provide the majority of metropolitan area jobs". During the same period minorities, primarily Blacks, have been moving into the central cities - increasing both their absolute number and their percentage of central city population in large SMSA's. The white population in these areas has been declining. Given these two sets of statistics and the likelihood that many of the eligible units of local government will operate their own CETA funded manpower programs, it appears possible that the planning and training - if geared to jobs within political boundaries - will not 
provide the optimum program for the central city disadvantaged. They may in fact be excluded, by virtue of geographical residence, from training programs and placements which may be most suited to their education, abilities and aspirations.

The CETA allocation formula may also result in areas with large number of disadvantaged persons, as opposed to unemployed persons, receiving lower levels of funding than they did in pre-CETA programs. The bill as passed by the House included only two elements in the Title I formula; the prior year's funding level and unemployment. The Senate bill proposed poverty and unemployment as the criteria. The final compromise gave precedence to past levels of funding 51

over measures of economic distress. The formula for distribution of Title I funds places three times as much weight on unemployment as on low income. Distribution of pre-CETA funds was based to a greater extent on poverty and other factors. The effect of the CETA funding formula is to increase funding to those areas where the ratio of adults in low income families to the number unemployed is low. The formula will eventually shift funds from the cities, not participating in consortia, to the counties. 53 Temporary stability of programs was guaranteed by the requirement that no prime sponsor may get more than $150 \%$ nor less than $90 \%$ of the previous year's funding. Over a period of several years, the level of funding going to different units will be 
adjusted with some areas gradually settling at lower levels than prior to CETA and other areas receiving increased funding. Table III illustrates the adjustment process in Fiscal Year 1975.

In each successive year, unless total funding is increased, the amount going to cities will continue to decrease. The disadvantaged minorities located in central cities will have less access to manpower services as the funding to their local unit of general government is reduced. Unless Congress amends the allocation formula to place more emphasis on low-income or poverty populations, the hard-core unemployed will receive less attention than they did under pre-CETA programs. A national study of participants in Title I programs demonstrates a basic trend under CETA: higher proportions of men, Whites, persons of prime working age, the better educated, the less disadvantaged, and persons who where unemployed rather than underemployed prior to entry in programs.

Although CETA legislation requires that participants be "economically disadvantaged, unemployed, or underemployed", the exact interpretations of these terms were, for the most part, left to the discretion of the prime sponsors. Many liberals feared that the disadvantaged, who rarely have powerful interest groups operating on their behalf at the state and local levels, would receive less 
TABLE III

PERCENT FISCAL YEAR 1975 OF FISCAL YEAR 1974 MANPOWER FUNDS, BY TYPE OF SPONSOR

Type of

Sponsor

County

Consortium

Balance of State
Percent FY 1975 Title

Formula Amount

Range

$53-180$

$68-292$

$63-143$

$70-127$
I Allocations ${ }^{a /}$ of Adjusted Amount $\mathrm{C} /$

Range

$90-150$

90

$90-150$

108

$90-134$

97

$90-127$

95

\begin{tabular}{lllll}
\hline All & 59 & $90-150$ & 96 \\
Sponsors & $53-292$ & 89 & $90-150$ \\
\hline
\end{tabular}

Source: Computed from Manpower Administration data

a/ Excludes consortium incentives, state funds for manpower services vocational education, and planning, funds for rural CEP's and for Guam, Virgin Islands, Samoa, and Trust Territories.

b/ Funds for programs corresponding with Title I.

C) Adjusted to provide each prime sponsor at least 90 percent but not more than 150 percent of prior year's fund.

SOURCE: William Muengoff and Lester Rindler, The Comprehensive Fmployment and Training Act (Washington, D.C.: National Academy of Sciences, 1976), p. 40 . 
attention than they had under the pre-CETA federal administration of manpower. Prior to CETA the local Community Action Agencies (CAA) were often involved in manpower programs - either as a prime sponsor or as the operating agency. The involvement of the CAA's benefitted the disadvantaged in two ways. The CAA's worked to organize and articulate the positions of the disadvantaged in manpower programs. Their organization and knowledge of bureaucratic processes aided the disadvantaged, who often lack the necessary skills, in obtaining a fair hearing in the policy making process. The CAA's also had a direct influence on the staffing of manpower programs. It was generally a policy in manpower programs associated with CAA's to employ clients as staff both during and after training. This practice could result in a significant number of the staff coming from the client population. CETA legislates no direct manpower authority or money to the CAA's and their role is left to the discretion of the prime sponsor. The CAA's are likely to play a lesser part than they performed previously. The manpower staff is likely to be hired under more traditional methods, and the proportion of the staff who were or are disadvantaged clients will decrease. The diminished importance of CAA's in manpower programs is also likely to quiet the political voice of the disadvantaged groups in these programs. 
Allocations and the Disadvantaged in Portland, Oregon

The shifts in manpower funding under CETA which have been noted nationally are present in the Portland area. Funds going to the county governments and the state have increased. Table IV demonstrates the breakdown of CETA funding.

Characteristics of the population being served by the different prime sponsors in the Portland metropolitan area were essentially projections at the time of the interviews in February and March 1975. The prime sponsors had just begun operating their Title I programs and were attempting to implement their new Title VI programs. In the Portland metropolitan area program directors do appear to be carefully following the national guidelines and are giving a high priority to disadvantaged persons. Although priority is given to the disadvantaged, the client population is likely to be different than under pre-CETA programs. The reason for the expected change is that the populations of the prime sponsors of CETA are different than under earlier programs. The majority of the clients of the major pre-CETA program, CEP, were Black. Most of the Black population in the Portland area resides in the City of Portland. According to the $1970 \mathrm{U} . \mathrm{S}$. Census there were 372 Black residents in Clackamas County; 188 Black residents in Washington County; and 22,155 Black residents in Multnomah County, of 
TABLE IV

TOTAL CETA MONEY TO PORTLAND METROPOLITAN AREA

FEBRUARY $1975-\$ 35,590,008$

A. TOTAL CETA MONEY TO OREGON - $\$ 34,308,008$

State of region
(administration)

$\$ 972,780$

Lane county

$I-\$ 1,314,918$

II - $\$ 1,292,515$

VI - $\$ 1,510,722$

Portland

$I-\$ 3,919,050$

II - \$981,821

$V I-\$ 1,420,039$
Clackamas

county

$I-\$ 788,764$

$V I-\$ 358,987$

Oregon's other

29 Counties

$$
\begin{array}{r}
I-\$ 5,058,454 \\
I I-\$ 4,572,149 \\
V I-\$ 4,504,699
\end{array}
$$

Multnomah Washington Consortium

$$
\begin{array}{r}
I-\$ 1,413,624 \\
I I-\$ 600,000 \\
V I-\$ 689,878
\end{array}
$$

Mid-Willamette Valley Consortium

$$
\begin{array}{r}
I-\$ 1,630,732 \\
I I-\$ 1,623,609 \\
V I-\$ 1,030,024
\end{array}
$$

\section{CETA III}

American Indians $\$ 521,341$

(Includes $\$ 196,557$ to Portland

Urban Indian Center)

Oregon Rural opportunities

Center $\$ 794,500$ 
TABLE IV (Continued)

B. TOTAL CETA MONEY TO CLARK COUNTY, WASHINGTON

$I-\$ 688,000$

III - \$224,000 (Supplemental funds for Summer Youth Frogram)

$V I-\$ 370,000$

SOURCE: Willamette Week, March, 1975. 
which 98 percent resided in the City of Portland. Consequently, since clients must reside within the geographical boundaries of the prime sponsor, the number of Blacks served by four of the five prime sponsors is low. The number of Mexican-Americans is likely to increase. But, overall the number of minority clients served in the Portland metro area is likely to decrease. The county programs are likely to have an older, better-educated, and less disadvantaged clientele than the city program.

In the City of Portland program there also appeared to be a slightly different philosophy emerging among CETA administrators. The CEP program included among its participants many "marginal" disadvantaged persons - persons whose background or motivation made their ultimate performance in the labor market questionable. Several of the persons involved in CETA mentioned that CEP "recycled" too many participants and wasted valuable training slots on persons who were not sufficiently motivated to obtain and hold a job. City Commissioner Charles Jordan, who is in charge of CETA I and II, stated, "The situation was pathetic before. People who were in the program were not qualified. Now, under the City's program, only qualified people are in the program. Specific instructions have been given to the subcontractors to take only people who are really motivated, want to be trained and are ready ... cream the best of the disadvantaged, get them placed, and then take the ones that 
will be time consuming." ${ }^{55}$ Two persons interviewed did feel that the new CETA trainees are quite superior in education to prior CEP trainees. They also felt that the "creaming" was unjustifiable, and that CETA was failing to serve the real disadvantaged who needed training. The marginal costs and services required by the less disadvantaged clients are lower. Commissioner Jordan's position can be justified as a rational strategy which will ultimately benefit the disadvantaged community. But, if the intent is to serve the disadvantaged, the city must ensure that its subcontractor is not just admitting the applicants easiest to train or those who could obtain a job without CETA persons who although presently unemployed would not be considered disadvantaged in the usual sense. City personnel assured the author that there would be close control, but could not give satisfactory answers as to how the monitoring and evaluation system would be designed or implemented. 58,59 The program at the time of the interviews was just beginning operation, and only an evaluation at a later time will answer the questions raised concerning the City's clientele. No information about the ultimate effect of different prime sponsors competing for job placements was available at the time of this review. Persons interviewed expected to use the Employment Service for placement as well as their own individual job developers. But, it is possible that the elected officials of the different prime sponsors may 
attempt to influence employers in their areas to accept trainees from their manpower programs. Commissioner Jordan was hopeful that the City would be able to use leverage not available to previous manpower agency administrators to open up jobs to their trainees. The effect of the geographical fragmentation of CETA on job placement opportunities is unknown.

The local CAA, the PMSC, is not playing an important part in the CETA program. The City originally intended to contract with the Portland CEP, which is under the PMSC, to perform orientation, Intake, and Assessment for CETA I and II. This contract was ultimately let to Portland community College after a public hearing packed by protesting persons primarily connected with the PMSC. The manpower staff hired by the City does not appear to be following the CEP pattern of hiring many of its own trainees in the program. Mr. C. Gilchrist, Director of PMSC states, "The City's CETA I program is only hiring the CEP people with degrees or fairly established types ... They are an institution and are not going to hire the poor as we did." ${ }^{61}$ PMSC is concerned that the essential rapport and empathy which is necessary to get failures reinvolved in the system will be lacking in the City's program. ${ }^{62}$ Commissioner Jordan feels this criticism is irrelevant. To help people and make good decisions it is absolutely critical to have qualified personnel. He feels the criticism is a symptom of the "reservation syndrome" 
encouraged by federal programs in the $1960^{\prime} \mathrm{s}$. Instead of remaining among their "own kind", the disadvantaged must get out of the ghetto and learn to use the whole city and its institutions if they are to succeed. ${ }^{63}$ There are certainly fewer direct jobs for the disadvantaged under CETA than under CEP.

\section{SUMMARY}

CETA was originally intended to create a decentralized decategorized manpower delivery system in which prime sponsors could develop flexible comprehensive manpower programs aimed at structural unemployment in their geographical area. The Congressional tendency to add categorical programs onto the CETA legislation has decreased the percentage of CETA funds available for flexible prime sponsor use. The inclusion of Title VI and youth programs aimed at cyclical unemployment strained the abilities and resources of CETA prime sponsors.

CETA's definition of eligibility for prime sponsors created the potential for fragmentation, duplication, and inefficiency as many prime sponsors develop independent manpower programs in the same labor market area. Potential economies of scale are lost as each prime sponsor offers similar services. No coordination mechanism exists between prime sponsors, and there is apparently little communication between units operating in the same labor market area. 
As each CETA prime sponsor operates independent manpower programs, the disadvantaged minorities concentrated in the political unit of the city may be denied access to suitable jobs located within Lise boundaries of another prime sponsor. Program combinations offered differ by the type of sponsor with cities concentrating on classroom training and counties devoting more funds to work-experience programs.

The CETA allocation formula places three times as much weight on unemployment as it does on low income. Manpower funds at the local level are gradually being shifted from the cities to the counties and consortia. This process will result in a reduction in funds avilable to the prime sponsors within whose geographical boundaries many of the most disadvantaged and minorities reside. A basic trend apparently developing under CETA is for the participants to include higher portions of men, whites, persons of prime working age, the better educated, and the less disadvantaged. Shifting the geographical units receiving manpower funds has resulted in shifting the population served by manpower programs. It is not possible to determine at this time whether city prime sponsors are placing the same emphasis on training the hard-core unemployed as existed under the previous federal manpower programs. 
39. William Mirengoff and Lester Rindler, The Comprehensive Employment and Training Act (washington, D.C.: Printing Publishing office, National Academy of Sciences, 1976), p. 94 .

40. Ibid., p. 21 .

41. 1974 Manpower Report of the President (Washington, D.C.: U.S. Government Printing Office, 1974), p. 197 .

42. Garth L. Mangum and John Walsh, A Decade of Manpower Development and Training (Salt Lake City: Olympus Publishing Co., 1973), p. 117.

43. Multnomah Washington Manpower Consortium, Modified Grant Application to Manpower Administration, U.S. Department of Labor, Seattle, January 1, 1975, p. 15 .

44. Center for Population Research and Census, Portland State University, "Population Estimates of Counties and Incorporated Cities of oregon", July 1, 1974, p. 1 .

45. Ibid., p. 5 .

46. Interview with Joe white, manpower aide to City of Portland Commissioner Charles Jordan, Portland, Oregon, February 18, 1975.

47. Interview with Phil McLarin, aide to City of Portland Mayor Neil Goldschmidt, Portland, Oregon, February $28,1975$.

48. Interview with Larry Macnab, Executive Secretary for the Oregon Balance of State Plan, Salem, Oregon, March 20, 1975.

49. U.S. Congress, Senate, Subcommittee on Employment, Poverty, and Migratory Labor of the Committee on Labor and Public Welfare, Job Training and Employment Legislation, 1973, Hearings on S.1559 and S.1560, 93rd Cong., lst Sess., 1973, p. 155. 
FOOTNOTES - CHAPTER III (Continued)

50. Kenneth McLennan and Paul Seidenstat, New Business and Urban Employment Opportunities (Lexington: Lexington Books, 1972), p. 20 .

51. William Mirengoff and Lester Rindler, p. 27.

52. Ibid., p. 35 .

53. Ibid., p. 38 .

54. Ibid., p. 133 .

55. Interview with City of Portland Commissioner Charles Jordan, Portland, Oregon, February 20, 1975.

56. Interview with Susan Wagenblast, Counselor, Portland, Oregon, February 10, 1975.

57. Interview with Cleveland Gilchrist, Director, Portland Metropolitan steering Commission, Portland, Oregon, February 10, 1975.

58. Interview with Commissioner Charles Jordan.

59. Interview with Patrick Borunda, Manpower Director for City of Portland, Portland, Oregon, Fehruary $10,1975$.

60. Interview with Commissioner Charles Jordan.

61. Interview with Cleveland Gilchrist.

62. City of Portland Public Hearing on CETA I \& II, Portland, Oregon, December 24, 1974.

63. Interview with Commissioner Charles Jordan. 
CHAPTER IV

THE COMPREHENSIVE EMPLOYMENT AND TRAINING ACT: PLANNING, ADMINISTRATION AND ACCOUNTABILITY

AT THE LOCAL LEVEL OF GOVERNMENT

CETA PLANNING

Prior to the passage of CETA, manpower planning at the local level was primarily limited to participation in the Cooperative Area Manpower Planning System (CAMPS) introduced by the U.S. Department of Labor in 1967. The CAMPS program, which was discussed in Chapter II, was intended to provide comprehensive manpower plans for manpower programs under the DOL at the local and state governmental levels. The primary benefit of the early CAMPS was to provide an opportunity for communication between people involved in the manpower system rather than a meaningful planning process. In 1971 CAMPS was restructured in an attempt to make the program more influential. Local recommendations were to be taken into account by federal administrators and planning grants provided funds to state and local units to hire manpower planning staffs. The new structure provided for a state Manpower Planning Council (SMPC) under the governor; an Area Manpower Planning Council (AMPC) under elected officials of the largest city in each CAMPS area; and an Ancillary 
Manpower Planning Board (AMPB) for the balance of the state. In 1973, in an administrative move intended to precede revenue-sharing, the DOL announced that local officials would be given more freedom in recommending how EOA and MDTA funds were to be used in their area. When CETA became law in December 1973, the CAMPS was discontinued as new regulations came into effect. Because the local and state CAMPS Councils lacked the power to institute their plans, the CAMPS' manpower plans were generally a token exercise. But, the CAMPS program did familiarize those involved with the manpower planning system, and it provided a channel of communication between manpower agencies. More importantly, through the planning grants it provided funds which developed a core of manpower planners at the local and state levels of government.

CETA placed an emphasis on local planning as an essential component of a decentralized manpower system. Planning councils are required at the state and local prime sponsor levels to submit recommendations to the prime sponsor on program plans, goals, policies and procedures, and to monitor and provide objective evaluation of the manpower programs. The members of Planning Councils are to be appointed by the prime sponsor. To the extent practical, members are to represent the client community, community-based organizations, the employment service, education and training 
agencies, business, and labor. Funding for Planning

Council staff is provided by the prime sponsor. The prime sponsor with the aid of the Planning Council was intended to develop a comprehensive manpower plan geared to meeting local and state needs.

The role of the advisory Planning Council will probably vary between prime sponsors due to the differing administrative and political environments. But, the Planning Council does have broader responsibilities than previous councils. It is possible that an active council could provide the prime sponsor with expertise and information from groups with differing backgrounds which are concerned with manpower. Their input into the manpower plan and their interaction with CETA administrators may provide broader participation in manpower planning than existed previous to CETA.

Considering the limited experience of new CETA prime sponsors prior to 1973, the Congressional sponsors had high expectations. Community based organizations, the Employment Service, Community Action Agencies and others have been participating in manpower programs for more than a decade, but generally the important decisions were made by the federal government. The proliferation of manpower programs under CETA may lead to a critical shortage of qualified, experienced manpower personnel. The responsibilities for planning, administering, operating and evaluating manpower 
programs will require skills and competencies not required under previous federal legislation. If the goal of planning innovative, flexible, comprehensive manpower programs suited to the local area is to be realized, local sponsors must develop new methods of predicting local labor market needs; identifying problems that exist; setting objectives; devising solutions tailored to the local labor market; garnering resources wherever available then monitoring, evaluating and modifying the emerging programs to bring them to success. It is doubtful that many of the prime sponsors were equipped to deal with the range of problems in 1974. Whether they are developing the expertise to do a competent job is yet to be determined.

At least in the short run CETA I plans can be expected to closely follow the models provided by previous federal programs. The inexperience of elected officials, staff and the Planning Council combined with federal pressure to get programs into operation do not contribute to a thoughtful, meaningful planning process. Consequently, prime sponsors' plans for CETA I are likely to be a collection of previous programs drawn together under a new administration. In the first few years under CETA, the local administration and Planning Council are likely to plan programs similar to federal programs with which they are familiar. Hopefully, as experience in planning, evaluation and administration grows, experiments and innovations will presumably be made 
to align the programs more closely to local needs.

Regardless of the planning problems encountered under the first years of CETA, planning for manpower programs is currently a state and local, rather than a federal responsibility. This shift in functions is certain to have an effect on the process of manpower planning as well as the final outcome, the manpower plan. Elected officials and prime sponsors' staffs will be more involved in making decisions which will affect their area. The new responsibilities will generate an increased interest in manpower programs and the employment situation which in the past received only cursory attention at the prime sponsor level.

\section{Planning in the Portland Metropolitan Area}

Planning has not been a strong point of any of the programs operating in the Portland metropolitan area. The lack of firm information from the federal government concerning funding levels for the first year of operation and short federal deadlines for grant applications under CETA have been important factors in the low priority given to planning by prime sponsors. For example, the Consortium had twenty days to formulate their initial plan which was to become operational thirty days after submission. 66 Meaningful planning was impossible in such a short period of time. The emphasis has been on formulating some sort of acceptable application and getting the approved programs in operation. 
All programs appear to be so involved in reacting to various crises, deadlines and political pressure that the problems of initial program operation are consuming all of their time. The State Manpower Director summed up what appears to be the prevailing situation in the first year of CETA operation, "We don't have much time for meaningful planning. Now and for the past eight months we've mainly been concerned with crisis intervention." 67 There are no new innovative designs or programs, and persons interviewed felt that innovative programs geared to their area's needs were not likely to be developed in the next few years. All programs in operation are similar to previous federal programs, particularly the CEP program.

Although the City of Portland had been active in manpower planning under CAMPS and had a manpower staff prior to the passage of CETA, the City had more problems in developing and obtaining DOL approval for their CETA plan than did other prime sponsors in the Portland area. Other local prime sponsors had their programs in operation by Fall 1974, but the City of Portland did not obtain U.S. DOL finai approval until January 1975. Even given the longer planning time, the approved plan was perhaps overly complex and contained numerical placement goals which were unrealistic. For example, the original city goal was to place 3,000 persons in on-the-job training during the fiscal year. This was revised in Fall 1975 to 450 persons. Lack of experience 
in manpower programs by the newly elected official in charge of the programs and the newly hired staff led to unrealistic planning.

Accurate, useful local labor market area employment information did not exist in 1975. No serious plan to develop such an information system was under consideration by any prime sponsor. But, the Oregon state Employment Service Department of Research and Statistics, in conjunction with the U.S. Department of Labor, is currently attempting to develop such a system. Until the proposed system is operational, city and county prime sponsors are relying primarily on information from the Employment Service, their own job developers, and intuition. All persons interviewed complained that the lack of data hindered successful program planning, operation and assessment.

The role of the advisory Planning Council appears to differ by prime sponsor. In the City of Portland the Manpower Planning Council did not approve or participate in the plans for CETA I and II. In October 1975, the U.S. Department of Labor threatened to terminate funding for Portland's CETA I and II programs. One of the criticisms was that the Manpower Planning Council had not participated satisfactorily in the City's programs. The City increased the Planning Council's role and by June 1976, the U.S. DOL felt the participation was satisfactory. In the Multnomah-Washington Consortium the Planning Council was also not active in 
planning for the first year of CETA I and II due to time pressure. But, the director states that the Council is not a rubber stamp for the administration. Instead, it is a very hard working and vocal group and interaction between the Planning Council and the CETA administrators is continuous. The council includes Chicanos, who are suspicious of the administrators; business representatives; and persons representing various agencies and institutions. The director feels the twenty-four member council is too large and had expected the size to decrease by attrition, but this has not happened. The Planning Council is active, and participating in Consortium planning.

\section{ADMINISTRATION UNDER CETA}

Prior to CETA, administration of manpower programs was a responsibility of federal agencies, particularly the DOL. The subcontractors operating in local or state areas were generally not government units. Subcontractors were educational institutions, community based organizations, the employment service. etc. The Emergency Employment Act (EEA) of 1971 was the first major piece of manpower legislation which granted government units - including states, cities and counties - direct control of funding and operation of manpower programs. Thus, prior to CETA, lower government units had only limited experience in administering manpower 
programs, and perhaps no experience with manpower programs aimed primarily at training the hard-core disadvantaged. Government units proposing to become CETA prime sponsors were faced with the difficult task of assuming new responsibilities for which the majority had only limited experience. Three significant decisions had to be made by each prime sponsor in a short time period. These were: Should the unit form a manpower consortium with other units; (2) Where should the manpower unit be placed in the government's organizational structure; and (3) Should the government unit operate any or all of the manpower programs, or should it subcontract the operations to other agencies or institutions? Each decision would have a significant effect on the eventual manpower system.

The problems involved in forming consortia were discussed in Chapter III. Surprisingly, many prime sporsors considered the potential benefits from forming a consortium to outweigh the potential costs. The number of prime sponsors choosing to form consortia exceeded expectations. One hundred thirty-five consortia were established, comprising one-third of the 402 prime sponsors in fiscal 1975. It is impossible to determine at this time the number of consortia which cover the majority of their labor market area. The motivations for the formation of consortia are considered in the following paragraph. 


\begin{abstract}
"Several factors appear to be important in the formation of consortia: mutual trust developed in other joint enterprises; the desire of inexperienced prime sponsors to share the expertise of a more skilled unit; the wish to avoid direct political accountability for manpower programs through the use of the more anonymous consortium; and the desire to attain economies of scale and greater opportunities for job development in a broader labor market. Typically, after formation of a consortium, a form of joint powers agreement is drawn up, assigning overall responsibilities to a board or committee made up of delegates of each of the areas and assigning administrative responsibilities to a lead city or county, or to a unit reporting directly to the board."70
\end{abstract}

The second major decision facing new prime sponsors was the integration of their new manpower responsibilities into the existing government organization. Three conceivable organizational alternatives are: (1) create a separate department for manpower with equal status with other departments in the government; (2) place the manpower unit under the office of the chief elected official, insuring his attention to manpower issues; or (3) assign manpower functions to an existing department where it must compete with other units for the attention of the department head. The first alternative would presumably provide the manpower unit with the greatest visibility, accessibility to elected officials, and status. The third alternative is considered to minimize these factors. Regardless of the ultimate placement, CETA resulted in manpower units being institutionalized in the structure of the prime sponsor's government 
unit.

Prime sponsors could be expected to encounter difficulties in setting up administrative machinery for manpower functions. Experienced staff were in short supply. Even persons who had worked in the manpower field in the past were not equipped to deal with the new range of responsibilities required of a prime sponsor. DOL deadines for grant applications, insufficient information on funds available, changing appropriations, and the additional responsibilities of CETA VI and summer youth programs complicated administrative problems.

Administration in the Portland Metxopolitan Area

The breakdown in consortium negotiations which would have resulted in a consortium covering the labor market area was discussed in Chapter Three. A consortium between two counties was formed and overall responsibilities for the consortium was assigned to an Executive Committee consisting of the Chief Elected official in each county or his designate and one member of the Planning Council. The administrative unit is separate from both county governments and reports directly to the Executive Committee. The administrator is not responsible to other elected county officials. The administrator feels that decisions are generally made by his unit with the cooperation of the Planning Council, and the Executive Committee approves plans submitted to it. 
Aside from the chief elected officials, other county politicians are not very aware of the manpower programs or the 71 employment situation. Ninety-eight percent of the administrative unit's staff has no prior experience in manpower programs, including the director. Hiring inexperienced personnel was a conscious decision which was made in an attempt to get "fresh" personnel. 72

Although the City of Portland was interested in participating in a consortium, the withdrawal of the other potential prime sponsors from the negotiations forced the City to become its own prime sponsor. The inept handling of the consortium negotiations and other factors led to the termination of the majority of the existing manpower staff. A newly elected official, C. Jordan, interested in the manpower area, was assigned responsibilities for CETA. The grant application was delayed as the newly elected official and his staff attempted to put together a proposal. The manpower unit was placed in the existing Department of Human Resources with the manpower director reporting to the director of the Department. A new director for manpower was hired a month prior to the date that Portland's manpower programs were to become operational. The director had no prior experience in manpower programs. The lack of qualified staff greatly hindered preparation of a realistic manpower plan as well as effective administration of the 
program after it began operation. The City's program had continual problems which culminated in the Regional U.S. Department of Labor's office threat to terminate funding effective December 31, 1975. The Mayor of Portland and other Commissioners apparently did not interfere in the administration of the foundering program. The elected Commissioner in charge of the manpower program was directly involved with the program. In the fall of 1975 the manpower director was fired and a new director, familiar with the administration of social service programs, was hired. Title VI of CETA was placed by the Mayor under his office in the Department of Personnel. The director of Title VI had no prior experience in manpower, but the program was planned and implemented quickly and smoothly. The separation of CETA I and II from CETA VI freed the manpower unit under Commissioner Jordan to concentrate on the problems encountered in administering CETA I and II programs.

\section{THE DEIIVERY SYSTEM}

The third major decision facing new prime sponsors concerned the operation of manpower programs. For many prime sponsors setting up the necessary administrative machinery for planning, fiscal accounting, reporting, contracting, supervising and monitoring subcontractors, and assessing results strained existing capabilities. operating programs in which they had little or no prior experience 
would add an additional burden. Nevertheless, many prime sponsors seriously considered the extent to which the prime sponsor should operate programs directly. The factors favoring the subcontracting of program operation were:

- Subcontracting for program operation provided a clear demarcation between the prime sponsor's planning and administrative functions and program operation.

- Federal funding is always subject to change and/or delays. Subcontracting for services offered a flexible alternative to dealing with the attendant insecurities.

- Subcontracts could be let to other agencies if the existing contract performance was unsatisfactory to the prime sponsor. Subcontractors were responsible for performance.

- In many areas existing agencies had prior experience operating manpower programs and available facilities to continue programs under CETA .

Factors favoring prime sponsor operation of all or part of the programs were:

- In areas where no manpower programs had previously operated, such as rural or county areas, the prime sponsor was faced with a lack of alternative operators. The prime sponsor was forced to 
operate the programs or contract to agencies with no previous experience.

- Past performance by existing agencies may have been considered unsatisfactory to the prime sponsor.

- To maintain control over program operations, the prime sponsor may have desired to shift some functions to the prime sponsor while contracting for other activities.

- Political considerations, such as a prime sponsor's desire to weaken a community action agency, could have resulted in the prime sponsor choosing to operate the programs.

Under CETA, the proportion of programs being operated by the 73

prime sponsor has risen to 33 percent.

CETA granted authority to each prime sponsor to establish comprehensive manpower systems. Although the prime sponsor was expected to provide a range of services from orientation to followup, the legislation designated no presumptive deliverers of services. Prime sponsors were to give consideration to programs of demonstrated effectiveness and the use of existing services, but they were not required to use such programs or services. Agencies which had played important roles in manpower training and placement prior to CETA were forced to compete for contracts which could be 
granted by only one prime sponsor in any geographical area. The comprehensive manpower system model stresses the integration of various manpower services under the direction of the prime sponsor. A manpower center would offer a combination of services under one roof. Functional operations, such as classroom training, could be contracted out to agencies in different locations, but all activities would be coordinated. This model assumes the elimination of overlapping activities performed by different agencies within the prime sponsor's geographical area. Prior to CETA duplication and overlapping of functions between programs was a common occurrence. To achieve the goal of a comprehensive delivery system, the prime sponsor must choose to fund certain existing agencies while eliminating others. These decisions have and will continue to result in traumatic changes in existing programs and agencies. Those most affected by the decisions are likely to be community action agencies, community-based organizations, public vocational institutions, and the employment services - all of which were active in pre-CETA manpower programs. 74 Making radical changes affecting existing agencies, which may have a vocal local constituency, results in repercussions to agencies and local elected officials. Although prime sponsors can generally be expected to move towards the development of comprehensive manpower delivery systems, the transition will occur over several years. 
The Delivery System in the Portland Metropolitan Area

Prime sponsors in the Portland area have chosen different methods to deliver manpower services. In Spring 1974, the Multnomah-Washington Consortium made a careful study of available programs and the past operation of manpower programs in the City of Portland. The Director concluded that the programs had not been effective. The consortium decided to operate its own programs in order to find out how a manpower system worked. The Director felt that no one in Multnomah or Washington Counties knew any more than the consortium staff about running manpower programs. In early 1975 the consortium had subcontracts totalling about $\$ 50,000$. The remainder of the programs were operated by the prime sponsor directly. The Director is critical of subcontracting, because, in his opinion, it is too hard to terminate a contract once it has been let, even if performance is very unsatisfactory. once a contract has been let, political pressure to continue the contract is intense. Consequently, the Director prefers to run his own programs and maintain control.

The City of Portland chose to subcontract most of the operation of their manpower programs. Aside from fiscal accounting and the payment of client allowances, the city contracts for all aspects of program operation. The city 
commissioner in charge of manpower does not believe that the City should set up new bureaucracies to operate manpower programs when agencies with the necessary expertise already exist in the area. The existing agencies, financed generally by public funds, should be used rather than setting up duplicating city programs. Commissioner Jordan feels that the CETA money can be used most effectively by using the leverage supplied by the funds to make existing institutions more responsive. Organizations such as the Employment Service will continue to function regardless of CETA contracts. If CETA funds can be used to bring about institutional change, the long term benefits to the disadvantaged will be greater than if the City sets up its own service. Jordan sees the City's performance based contracts and the threat of contract termination as the levers which will provoke the envisioned changes in existing institutions. City representatives optimistically stated in early 1975, that contracts to subcontractors would definitely be terminated if performance was unsatisfactory. The following paragraphs describe the initial operation of CETA contracts. Table $\mathrm{V}$ demonstrates the breakdown of CETA funds in the City of Portland. The local community action agency, PMSC, was initially to obtain the Intake, orientation, and Assessment ( $I, O \& A$ ) contract. This contract was eventually let to the Portland Community College which had no previous experience in $I, O \& A$. The Director of the PMSC 
TABLE V

CITY OF PORTLAND'S CETA MONEY

\author{
CETA II \\ Manpower Staff \\ $\$ 918,821$ \\ CETA VI \\ Bureau of Personnel
}

$\$ 1,420,039$
Youth Manpower

Human Resources Bureau

$$
\$ 821,423
$$

Older Workers System

Human Resources Bureau

\section{ADMINISTRATION \\ Human Resources Bureau \\ Manpower Staff}

$\$ 201,082$

SUBCONTRACTS :

Intake, Orientation \&

Assessment - Portland

Community college
Pre-vocational \& Vocational Training POIC

$\$ 231,552$

$\$ 282,754$ 
feels this was done because of political pressure. The approval of the contract by the majority of the City Council was necessary. The PMSC director feels that several of the council members, who have had past conflicts with PMSC, communicated privately to the Commissioner in charge of manpower, that they would not approve a contract with PMSC. These allegations were denied by the commissioners during the public hearing. When the contract was lost the CEP program under PMSC was terminated. The local community action agency is no longer involved in the manpower delivery system.

A contract authorizing a local community-based organization, the Portland Opportunities Industrialization Center (POIC), to provide pre-vocational and on-the-job training services was let by the City without controversy in December 1974. The performance based contract placed responsibility for implementing theix portion of the manpower plan on the pOIC. As the program failed to meet expected goals in the first half of 1975, the City's manpower director considered terminating the POIC. Political pressure to continue the contract was intense, and the POIC contract was maintained. City contracts were also let to a private corporation to develop and implement a management information system and to develop the formats to provide the information for printouts on allowance payments. A contract was let with the 
Employment Service to provide job development, job placement and follow-up.

\section{ACCOUNTABILITY}

Underlying much of the argument favoring decentralization under CETA was the quest for accountability in decision making in manpower programs. Putting manpower decision making in the hands of local and state elected officials was expected to provide accountability. Local elected officials were presumed to be close to the people to be served by CETA, and the people could express their satisfaction or dissatisfaction with manpower decisions through the ballot box. Local officials were also presumed to he more knowledgeable about the needs of the local labor market than were Washington bureaucrats. The interaction between elected officials and representatives of business and labor were expected to result in manpower systems geared to local needs. Representatives of various groups on the Planning Council would allow for broad participation in manpower planning.

Local elected officials are certainly more responsive to the electorate than were federal bureaucrats. But, their responsiveness is often influenced by the political strength of the interested parties. Because manpower programs generally have low visibility and receive little attention 
by the average voter, the political pressures brought to bear on manpower decision makers are likely to come from groups directly involved in the manpower system - the clients, operating agencies, business and labor. The responsiveness of the elected official will depend on his priorities and the level of obligation existing between the official and what he considers the constituency responsible for his election. For example, a Black mayor elected in large part by disadvantaged voters, may be very responsive to the potential and existing client population of a manpower program where another mayor might be much more responsive to labor interests. Unless a scandal from misappropriation of funds, etc. centered media interest on manpower programs, it is unlikely that the elected official would need to consider the electorate as a whole in making manpower decisions. But, the tendency to broaden client groups under CETA, which was discussed in Chapter III, is one possible indicator that elected officials are making changes in response to their perceptions of the desires of the electorate.

The disadvantaged client population of manpower programs will in most cases be small, politically ineffective, and politically inactive. The exclusion of community action agencies from a mandated role in manpower programs will, in all probability, decrease their past role of organizing and articulating the positions of the disadvantaged population. 
Although client representatives were to be included on the Planning Council, such positions are often token appointments. Lacking managerial, political and bureaucratic skills, disadvantaged persons are often ineffective in such positions. Unless the client disadvantaged population has an effective lobby at the prime sponsor level they are not likely to be influential in manpower decision making. If there is increased accountability under the CETA legislation, it wiII be accountability to groups directly concerned with manpower and the provision of manpower services, rather than accountability to individual voters. Political activity surrounding CETA appears to approximate the model of "group theorist" David Truman in The Governmental Process. There appears to be little individual participation or interest in local manpower programs except by individuals representing the groups with which they are affiliated. Agencies which have been active in manpower programs in the past desire to continue their operations and are likely to use whatever political influence they have to maintain their position. The legislation, which stipulates that "to the extent practical" the Planning Council will have representative of community-based organizations, the employment service and agencies involved in training, gives the involved agencies a potentially effective voice in manpower decision making. Regardless of their past or present performance, many of these agencies have managed to 
maintain their position. As the prime sponsors become more experienced and assume increasing responsibility for comprehensive manpower programs, the power of these agencies and institutions may decline. But, as long as manpower funds are channeled through lower government units, interest group activity can be expected to continue to influence the decision making process.

In the Portland metropolitan area CETA I and II programs have low visibility. The Multnomah-Washington Manpower Consortium which operates separately from either county government and reports to an almost unknown Executive Committee, has received very little attention from the media. The problems of the City of Portland's manpower programs and statements from Commissioner c. Jordan have received press coverage in times of crisis. There has been no continuing coverage of any of the prime sponsor's programs by the media. Little information concerning the functioning of manpower programs or the decisions made by elected officials is easily available. The bureaucracies concerned appeared with one or two exceptions to be generally suspicious, defensive and secretive. Perhaps the level of disorganization and the inexperienced staff members contributed to the inability to answer questions or locate supposedly public documents. Regardless of the reasons, it is difficult to discover what is actually occurring in the programs. The average citizen is unlikely to even make the 
attempt. It is improbable that his vote will be influenced by a thoughtful assessment of the local CETA program. The proportionately large amount of CETA funds channeled into the Portland area has attracted interest group attention. The competition for subcontracts and the political pressure brought to bear when termination of contracts is threatened has been at times intense. When the city commissioner eliminated the PMSC as a subcontractor, all the city commissioners were lobbied, law suits were threatened, the public hearing was packed and the commissioner's political integrity was questioned. An agency which considered itself slighted by the oregon Balance-of-state administration threatened to march on the state capitol. Similar incidents were cited by representatives of all prime sponsors interviewed.

Unfortunately, the active involvement of at least a few of these agencies does not necessarily result in better manpower programs. The agencies' inclusion or exclusion from different programs appears to be more a question of politics than performance. All CETA administrators interviewed expressed dissatisfaction with the performance of at least one of their agencies under contract. Several of the agencies were criticized for their reputed unresponsiveness to disadvantaged clientele. The principal hope of the administrators is that the threat of "yanking the contract" will alter the agencies' performance. Yet, in several 
instances, the political pressure of the involved agencies has prevented the termination of contracts.

CETA has resulted in elected officials of local prime sponsors becoming much more actively involved in the manpower area. There are differences in the degree to which elected officials exercise administrative control of the programs, but elected officials do appear to be maintaining close contact with manpower administrators. In a period of high unemployment, CETA has been a visible, concrete attempt to deal with the problem. CETA VI, in particular, provided local elected officials with jobs during a period when they were critically needed. New channels of communication have opened between local units and affected groups. Elected officials are generally more responsive to local interests than were federal agencies.

\section{SUMMARY}

Major changes have taken place under CETA in the areas of manpower planning, administration and decision making accountability. At the prime sponsor level elected officials and administrative staff, who had only limited prior experience in manpower planning, are becoming increasingly involved. Planning is being integrated into manpower administrative units in local and state governments. Although meaningful planning was limited in the first year due to federal deadlines and the necessity of concentrating on 
program operation, planning systems have been developed and may function more effectively in the future. The role of the advisory Planning Council appears to vary between different prime sponsors. Councils are not the decision making body but their interaction with decision makers can affect final decisions.

Manpower administrative units have become institutionalized in prime sponsor government units. The importance of the unit varies between prime sponsors as does the degree of elected officials' involvement. The lack of qualified staff and the inexperience of many elected officials in the manpower area have generated problems in planning and administration. The changes involved in developing a comprehensive manpower system have altered the manpower delivery system. Traumatic changes affecting agencies and others involved in the delivery of manpower services have marred the transitional period. Two trends appear to be developing under CETA: (1) larger than expected numbers of prime sponsors are choosing to form consortia; and (2) many of the CETA prime sponsors are choosing to operate all or portions of their manpower programs. Accountability has improved as elected officials in prime sponsor areas become more involved in manpower decision making. Broad citizen participation in the manpower area has not developed. The average employed citizen is 
unlikely to be more aware of the functioning of CETA programs than he was of the earlier federal programs. Those directly involved in manpower programs are developing new channels of communication to decision makers. Interest group activity has been intense as involved agencies with constituencies at the prime sponsor level use their political resources in an attempt to influence decisions. There is little evidence that local elected officials either "know best what their local area needs are" or are able to develop innovative programs geared to the local labor market. Prime sponsors have tended to continue operating programs closely modeled after federal programs, particularly CEP. Political pressures appear to make termination of subcontracts difficult. Unless elected officals and administrators are able to resist such pressures, prime sponsor programs may become inflexible. 


\section{FOOTNOTES - CHAPTER IV}

64. 1974 Manpower Report to the President, p. 198 .

65. Garth L. Mangum and John Walsh, op. cit., p. 116.

66. Interview with Jack Wills, Director, Multnomah-Washington Manpower Consortium, Portland, Oregon, February $11,1975$.

67. Interview with Larry Macnab.

68. Telephone interview with Ken Rucker, U.S. Department of Labor Region X, Seattle, Washington, June 11, 1976.

69. William Mirengoff and Lester Rindler, p. 82.

70. Ibid.

71. Interview with Jack Wills.

72. William Mirengoff and Lester Rindler, op. cit., p. 96.

73. For a full explanation of the effect of CETA on these organizations see William Mirengoff and Lester Rindler, The Comprehensive Employment and Training Act, p. 103-116.

74. Interview with Jack Wills.

75. Interview with Commissioner Charles Jordan.

76. Interview with Cleveland Gilchrist.

77. City of Portland Public Hearing on CETA I and II, Portland, Oregon, December 24, 1974. 
CHAPTER V

THE IMPACT OF THE PORTLAND

CONCENTRATED EMPLOYMENT PROGRAM

Manpower progiams for the disadvantaged in the United States have been based on the theory that the programs, if successful, will result in the participants being better able to compete successfully in the labor market. 78 The ultimate objective is to improve the employment and earning experience of the disadvantaged target population. Although the evaluation of manpower programs is a new and growing field, little is known about the impact of the programs on the participants after they leave the programs. The national studies which have been done to date do indicate that the post-training experience of participants in manpower programs is substantially more favorable than that of control groups without training. Many more studies, particularly of a longitudinal nature, need to be done before firm conclusions can be made concerning the impact of manpower programs on participants.

over fourteen billion dollars was obligated by the U.S. Department of Labor (DOL) for work and training programs between fiscal years 1963 and fiscal year 1974 . Like all public programs manpower programs are financed by 
tax money from private citizens and businesses. The money spent on these activities could be used in other enterprises.

This dissertation is based on the premise that impact evaluations which seek to assess the extent to which longterm objectives are being met, ${ }^{81}$ need to be done to determine whether manpower programs were and are effective. Such assessments are necessary to provide a basis for good decision-making. The past practice of creating and continuing to fund programs on the basis of scarce knowledge about their impact is both inefficient and costly to society. 82 Deliberation on program continuation should include an assessment of program effectiveness.

This portion of the dissertation will not be concerned with administrative monitoring, or "process evaluation", but will concentrate on the impact, or "outcome evaluation", which is primarily focused on the capacity of the program to cause changes in those who are exposed to it. ${ }^{83}$ The only "outcomes" chosen to measure the impact will be tangible change in the income of participants of the manpower program and of the control group. This measure of manpower effectiveness was chosen because as Scanlon, et al, concluded, "Given the present state of knowledge, the most appropriate framework for effectiveness measurement at present is not the national economy ... but the success of the applicant in the labor market." ${ }^{84}$ other possible changes attributable 
to the program, such as decreased crime, improved selfimage, increased social and job satisfaction, and decreased governmental dependency, are considered outside the range of this study. This research will not attempt to investigate the questions of job displacement, or the impact of the program on local institutions and the local labor market. The assumption is made that an effective program has at least the following impacts on the local labor market: Increased labor market participation and a larger labor market supply; (2) Improved skills among those in the labor market; and (3) Reduction in labor market frictions due to the participants' increased familiarity with its institu85 tions. If income redistribution is included as an allowable goal for manpower programs, then the question of job displacement becomes less important in evaluating programs. A program which succeeds in reshuffling employment and decreasing the dispersion in the distribution of earned incomes would be considered a success.

THE PORTLAND CONCENTRATED EMPLOYMENT PROGRAM AND CETA

The general background information concerning the creation of the Concentrated Employment Program at the national level is contained in Chapter II. The Portland Concentrated Employment program (PCEP) began operation in September 1968 and was terminated in January 1975 when the 
City of Portland under CETA Title I contracted with the Portland Community College for manpower services. The PCEP acted as a subcontractor to the DOL. The local prime sponsor of the program was the portland Metropolitan steering committee (PMSC), a local community action agency. Contracts were let by the DOL to the PCEP generally on a yearly basis. Federal funds were allocated to the program under the Economic Opportunity Act (EOA) of 1964, Title I, Part B, and the Manpower Development and Training Act (MDTA) of 1967, Title II. Table VI shows the budgets for the years 1968 through 1975. The major purposes of the programs were to assist the economically disadvantaged persons within the defined target geographic area in finding employment and attaining higher incomes. The PCEP also attempted to provide substantial employment expansion and employment training for residents of the target area.

Briefly the PCEP operated in the following manner. Outreach staff in the community identified and referred potential enrollees to the PCEP. All applicants were required to meet the definition of disadvantaged as promulgated by the DOL. Once screening, selection, and enrollment were completed, the client was tested and counselled by an Employment Development Team. The client worked with the team to draft an Employability Development Plan (EDP) suited to the client's individual needs and the services offered by PCEP. The client was then enrolled in a 
TABLE VI

PORTLAND CONCENTRATED EMPLOYMENT PROGRAM BUDGETS AND ENROLLMENTS: 1968-1974

\begin{tabular}{|c|c|c|c|c|c|c|c|}
\hline Date & $\begin{array}{c}\text { Contract } \\
\text { Number }\end{array}$ & $\begin{array}{l}\text { Cost per } \\
\text { Enrollee }\end{array}$ & $\begin{array}{l}\text { Total } \\
\text { Funds }\end{array}$ & EOA & $\begin{array}{l}\text { MDTA- } \\
\text { Inside }\end{array}$ & $\begin{array}{l}\text { MDTA- } \\
\text { Outside }\end{array}$ & $\begin{array}{l}\text { Planned } \\
\text { Enrollment }\end{array}$ \\
\hline $\begin{array}{l}1-16-74- \\
1-10-75\end{array}$ & $46-48$ & $\$ 1226 *$ & 981,000 & $\$ 780,300$ & $\$ 200,700$ & None & $800 *$ \\
\hline $\begin{array}{l}3-1-73- \\
1-15-74\end{array}$ & $36-48$ & $\$ 1667$ & $\$ 1,000,019$ & $\$ 505,000$ & $\$ 379,614$ & $\$ 243,386$ & 600 \\
\hline $\begin{array}{l}11-5-71- \\
2-28-73\end{array}$ & $26-48$ & $\$ 1843$ & $\$ 1,474,000$ & $\$ 880,000$ & $\$ 290,000$ & $\$ 304,000$ & 800 \\
\hline $\begin{array}{l}12-3-70- \\
11-4-71\end{array}$ & $16-48$ & $\$ 2075$ & $\$ 1,681,000$ & $\$ 880,000$ & $\$ 436,847$ & $\$ 364,153$ & 810 \\
\hline $\begin{array}{l}1-6-70 \\
12-2-70\end{array}$ & 0681 & $\$ 1290$ & $\$ 1,161,503$ & $\$ 337,503$ & $\$ 308,573$ & $\$ 515,427$ & 900 \\
\hline $\begin{array}{l}9-68 \\
1-5-70\end{array}$ & $168 I-41 * *$ & $\$ 1221 * \star$ & $915,756 * \star$ & $\$ 880,000 * *$ & $\$ 115,756 * *$ & & $750 * *$ \\
\hline Total & & $\$ 1531$ & $\$ 7,213,278$ & $\$ 4,262,803$ & $\$ 1,731,490 \$$ & $1,426,966$ & 4,660 \\
\hline
\end{tabular}

Cost per Errollee and Planned Enrollment figures are estimates, not actual figures. EOA funds are allocated through the Economic opportunity Act. 
MDTA-Inside funds were controlled by PCEP and funded "institutional training" programs which have higher costs per enrollee than on-the-job training and work experience programs.

MDTA-Outside funds were controlled by the Employment Service and vocation Education.

* Estimate by Region X, Department of Labor - CEP figure was 1050, but Regional officials stated that this was an unrealistic figure.

** DOI could not furnish information on this contract. Figures are estimates given by PCEP Director.

Source: Department of Employment and Training, Region X, U.S. Department of Labor, 1975 
program of varying length which oriented him or her to the world of work and specific job requirements. This first stage was referred to as Intake, Orientation, and Assessment $(I, O, \& A)$. The second stage consisted of remedial education if necessary and training - general, job-specific, or on-the-job training. These services were generally provided by other agencies subcontracting with PCEP. Throughout the client's enrollment in the program counselling and various supportive services, such as medical services, day-care, etc., were available. Upon completion of training the client was hopefully placed in a suitable job. The particular combination of services utilized depended upon the type of disadvantage confronting the client, and the kind of employment desired. A client was contacted at intervais of thirty, sixty, and ninety days after job placement. No form of follow-up continued after ninety days, and very little is known about participants' incomes after this period. Evaluations of the internal administration of the PCEP and audits have been performed, but no long-term impact evaluation of the PCEP has been made up to the present time. The City of Portland's CETA I program is closely modeled after CEP. Although contracts are administered by the City and the subcontracting agencies are different in some cases, the basic form of the City's manpower programs is similar to that of the PCEP. The City is also serving the same geographical area although clients may also come 
from other areas in the city. The present programs consist of a comparable set of components directed more or less at similar target groups and designed around a particular set of assumptions relating the causes and effects of the groups' perceived problems in the labor market. For example, the PCEP orientation connected with institutional training assumed that the primary problems facing the client were insufficient knowledge of the labor market and a lack of basic skills. Consequently, the primary services offered were intake to identify persons with low skills, counselling to determine vocational interests, orientation to the work world and its requirements, a classroom training service to impart necessary job skills, a stipend to provide financial support during training, and a placement service to match clients to available jobs. The basic package of services offered under CETA I in the City of Portland is based on the same model. The similarity of the programs increases the importance of an evaluation of the impact of the PCEP on its participants. Given that the purpose of both programs is primarily to increase the income of participants, the impact evaluation of the PCEP will provide insight into the validity of the model on which both programs are based. The information on the PCEP may provide the present CETA decision makers with new facts which may assist them in making future manpower decisions. 
RESEARCH DESIGN

The research is a retrospective study relying on the use of existing records at the PCEP.

In September 1973 the author was given full access to all the files of past enrollees in the PCEP, and the files of those persons who had been admitted to the PCEP but had failed to participate. From these files the author extracted the information shown in Table VII on every individual whose file was closed between 1968 and 1972. Only complete and available files were included. 87 Individuals who completed the program as well as dropouts who received part, but not all, of the intended program were included in the 88

treatment group. Other research has found that exposure to the program, regardless of completion, does result in changes which must be included in the evaluation.

The Control Group

A basic problem in measuring the impact of manpower programs is to obtain valid evidence on the magnitude of each outcome variable which would have emerged had the program not existed. Studies lacking control groups leave unanswered the vital question of whether training is the relevant variable which explains post-training gains or losses. The ideal solution is to randomly select a control group by dividing like interested applicants in half - providing one group with the services of the manpower program 
and excluding the other group, the control group, from the manpower services provided by the program. This ideal was not a feasible alternative for this retrospective study. Another alternative is to compare the pre-training and the post-training earnings experience of participants. The author recorded the self-reported income for the 52 weeks preceding program application for all involved individuals. This information was not atilized in evaluating the impact of the program. The author concluded that the self-reported income was unreliable. PCEP intake personnel indicated that applicants were aware of the low income eligibility requirement and that generally the income reported was not checked. Consequently, applicants were possibly motivated to underreport their income to qualify for the program. Furthermore, groups with high unemployment levels can be expected to have high unemployment levels later, but they will usually have greater than average increases in employment and earnings. This is particularly true for youths and reentrants to the labor force. Such income gains are not necessarily attributable to training. The control group used in this research is a group of persons who are statistically equivalent to the enrollees in the PCEP in all respects as far as demographic variables, their application to the program, and their eligibility for the program; but, who for some unknown reason, did not enter the program. Other research has concluded that, "until new results 
emerge, qualified and interested nonenrollees seem to be more appropriate control groups than does the general target 91 population." They, like the program participants, showed an interest in the program and were able to meet the pro92 gram's entrance requirements. Qualified nonentrants may be slightly less qualified or conversely, slightly more qualified than the entrants. Other research and the PCEP personnel have indicated that reasons for non-entrance are varied and may be due to timing, fear of the program, finding a job on their own, moving, etc. All eligible individuals who had applied but failed to participate in the PCEP and whose files contained the essential information were included in the control group.

\section{Income Data}

The long-range followup of persons who participated in the manpower training programs has proved to be both difficult and costly in previous attempts by other researchers. Cost estimates on national surveys of personal interviews with exenrollees after six to twelve months ranged in 1972 from fifty to one hundred and fifty dollars per person. Response rates are frequently unsatisfactory. ${ }^{95}$ The disadvantaged population which is the focus of the manpower programs evidences certain characteristics that make locating, meeting, and interviewing exenrollees very difficult. The PCEP attempted in 1973 to survey exenrollees in one 
component of the program. The response rate was less than ten percent. Other means of obtaining follow-up data are necessary if evaluation of program impact is to be effected.

The United States Social Security Administration (SSA) has recognized that their data, if suitably used so as to provide confidentiality, is a useful source of income data for evaluating the impact of manpower programs. This research uses SSA data to obtain follow-up information on the incomes of the control group and the exenrollees in the PCEP. The earnings reported to the SSA are not total earnings, but taxable earnings up to a maximum of $\$ 9000$ in 1972 and $\$ 10,800$ in 1973. This maximum does not appear to be a serious limitation considering the expected earnings for most participants in manpower programs. 97 The SSA records cover ninety percent of paid employment under nationally uniform laws and procedures. All local units of government in the Portland area and the local community action agency are covered by the SSA. The response rate is reportedly over 98 percent with accurate Social security numbers. The records collected by the SSA are confidential. The SSA provided the author, on a reimbursable basis, the earnings information for coded cells containing five or more individuals. The author provided the SSA with punch cards with the following data elements on PCEP exenrollees and the control group: 
Social security number

Last name

Five digit numeric code - classifying individuals by

Treatment or Control Group, Sex, Race, Age, and Education

The SSA matched the punch cards to its master file, and for every match, wrote out the five digit code field and the taxable earning for the years 1972 and 1973. The SSA sorted the resultant file according to the five digit code and aggregated the incomes of 3330 individuals in cells of five individuals or more. Cells with less than five individuals were deleted. $^{99}$ The SSA then provided the following information for 1972 and 1973 on each coded cell: minimum and maximum income; frequence distributions on total earnings by year, mean earnings by year, standard deviations on the mean, and median earnings including and excluding zero earners. The information was provided on computer tape, which unfortunately was not usable, and an accompanying printout.

\section{Problems in Using Social Security Administration Data}

Several problems are involved in the use of SSA data. For each year there is only one earnings amount reported. No information concerning the period of employment covered is retained. Consequently, it is impossible to compute hourly wage rates or to determine whether the reported 
earnings are for a one-month or a twelve-months period. The coverage under the SSA has not been universal. Federal employees, who might be manpower participants, are not included. Employees of nonprofit organizations and government units may not be covered. Wages paid for yard work, domestic services and other "odd jobs" often may not be reported. Earnings reported included military wages without a label.

There is a built-in time lag before wage data reported by employers can be obtained from the SSA summary earnings records. SSA records are not 99 percent complete for nonfarm wage and salary data until october of the following calendar year. Preparing special research data is not the primary purpose of the SSA. Retrieval of research data may be given a low priority. The information for this research was submitted in October 1974. The most recent SSA summary earnings records at that time were for 1973 earnings. The complete SSA compilation of the earnings data was received by the author during the summer of 1975. Thus, complete earnings data was not available until one and a half years after the last year being examined.

The most serious limitation to research encountered in the use of SSA data is imposed by the necessity of maintaining confidentiality of individual records. Income information is only reported in cells of five or more individuals. This requirement seriously limits the number of 
independent variables that may be included in a cell code unless the sample size is very large. The five variables included in this research were considered important in influencing income levels. Many independent variables, such as criminal record, head of household, handicaps, etc., could not be included. Furthermore, the reporting of group earnings severely limits the ability of the analyst to manipulate the data. Although the cells can be aggregated - i.e., the total earnings of the group aged $0-20$ years could be added to the total earnings of the group aged 21 25 years - the group earnings cannot be disaggregated since individual incomes are not reported. These limitations inherent in the use of SSA data should be kept in mind when reviewing the findings of this research.

The Dependent and Independent Variables

Manpower program impact evaluations involve the measuring of relationships between program goals, the dependent variable, and a chosen group of independent variables. The evaluation attempts to discover which independent variables are important and the nature of the relationship. It is assumed that the dependent variable is a function of more than one independent variable. The dependent variables were limited in number in order to obtain SSA data, are treatment, age, sex, race, and years of formal education. 
My hypotheses concerning these variables are as

follows:

1. Participation in the PCEP will have a significant positive impact on incomes. Other research has found individuals do benefit from participation in manpower pro101

grams. The income levels of participants will be significantly higher than those of the control group.

2. The age of persons included in the study will influence income. Factors associated with age - such as increased labor market experience, maturity, family responsibilities, etc. - should result in adults being more stable workers and attaining higher income than youths. Labor market discrimination against hiring older workers, and particularly disadvantaged older workers, will result in lower incomes for persons forty-five and over.

3. Sex of persons included in the study will have an influence on income. This hypothesis is based on the assumption that women generally have a weaker labor force attachment than men, and that sex discrimination in the U.S. has resulted in lower incomes for the female labor force than the male labor force. In 1969 the earnings of fulltime women workers was 60.58 of full-time men's earnings 102

nationally. Female incomes will be lower than male incomes.

4. The Race of persons included in the study will have an influence on income. Discrimination in hiring and 
promotion on the basis of race has been well documented in 103

the U.S. Substantial economic disadvantage remains for nonwhites, even at high levels of aggregate demand. 104 The mean and median incomes of nonwhites are lower than those of whites, and the ratio of nonwhite to white earnings is declining in all major geographical areas of the U.S. except 105

the South. Nonwhites will have lower incomes than

whites.

5. Years of education attained by persons in this study will have a distinct influence on income. Education is often used as a screening device by employers. Increased years of education generally improves opportunities for employment in higher income jobs. Education is positively correlated with income in the U.S. Persons with twelve years of education and over should have higher incomes than those with less education.

6. Interactions between the five independent variables will influence income.

Table VII provides an explanation of the code submitted to the SSA and the approximate number of persons in each coded cell. 
TABIE VII

INDEPENDENT VARIABLES

PCEP PARTICIPANTS AND CONTROL GROUP 1968-1972

5 Digit Code - I II III IV V

\begin{tabular}{|c|c|c|}
\hline I & - Treatment & $\begin{array}{l}\text { 1. Participant of PCEP } \\
\text { 2. Control Group }\end{array}$ \\
\hline II & - Sex & $\begin{array}{l}\text { 2. Male } \\
\text { 2. Female }\end{array}$ \\
\hline III & - Race & $\begin{array}{l}\text { 1. Black } \\
\text { 2. White } \\
\text { 3. Mexican American } \\
\text { 4. American Indian } \\
\text { 5. Other }\end{array}$ \\
\hline IV & - Age & $\begin{array}{l}\text { i. } 0-20 \text { years of age } \\
\text { 2. } 21-25 \text { years of age } \\
\text { 3. } 26-44 \text { years of age } \\
\text { 4. } 45 \text { years of age and over } \\
\text { 5. Blank }\end{array}$ \\
\hline $\mathrm{V}$ & $\begin{array}{l}\text { - Completed } \\
\text { Years of } \\
\text { Education }\end{array}$ & $\begin{array}{l}\text { 1. } 1-9 \text { years completed } \\
\text { 2. } 10-11 \text { years completed } \\
\text { 3. } 12 \text { years and over completed } \\
\text { 4. Blank } \\
\text { 5. Blank }\end{array}$ \\
\hline
\end{tabular}

Example: 11212 - Treated, Male, White, 0-20 years, 10-11 years of education completed 
TABLE VII (Continued)

FREQUENCY BY CODED CELL - PCEP PARTICIPANTS

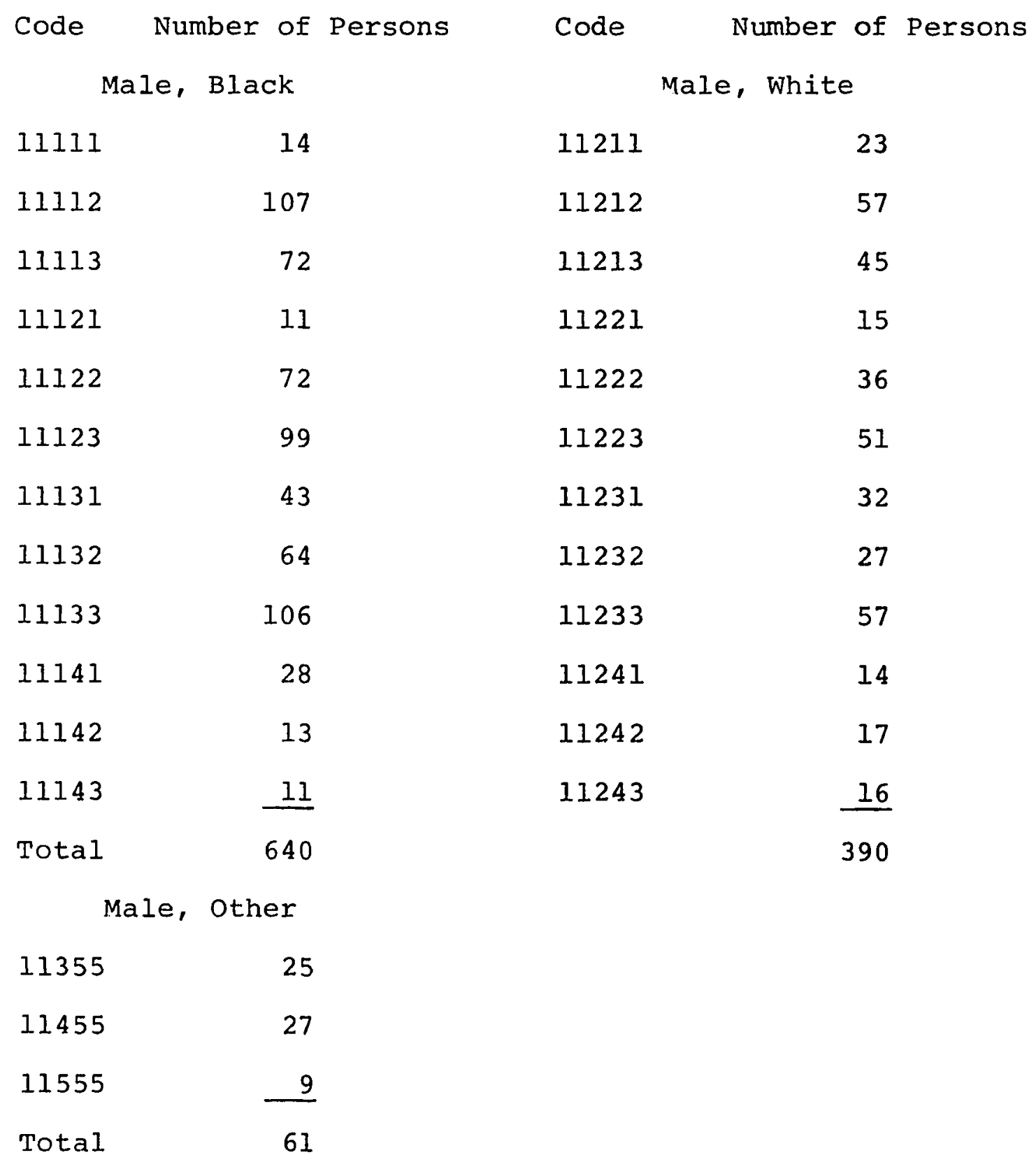


TABLE VII (Continued)

FREQUFNCY BY CODED CELL - PCEP PARTICIPANTS

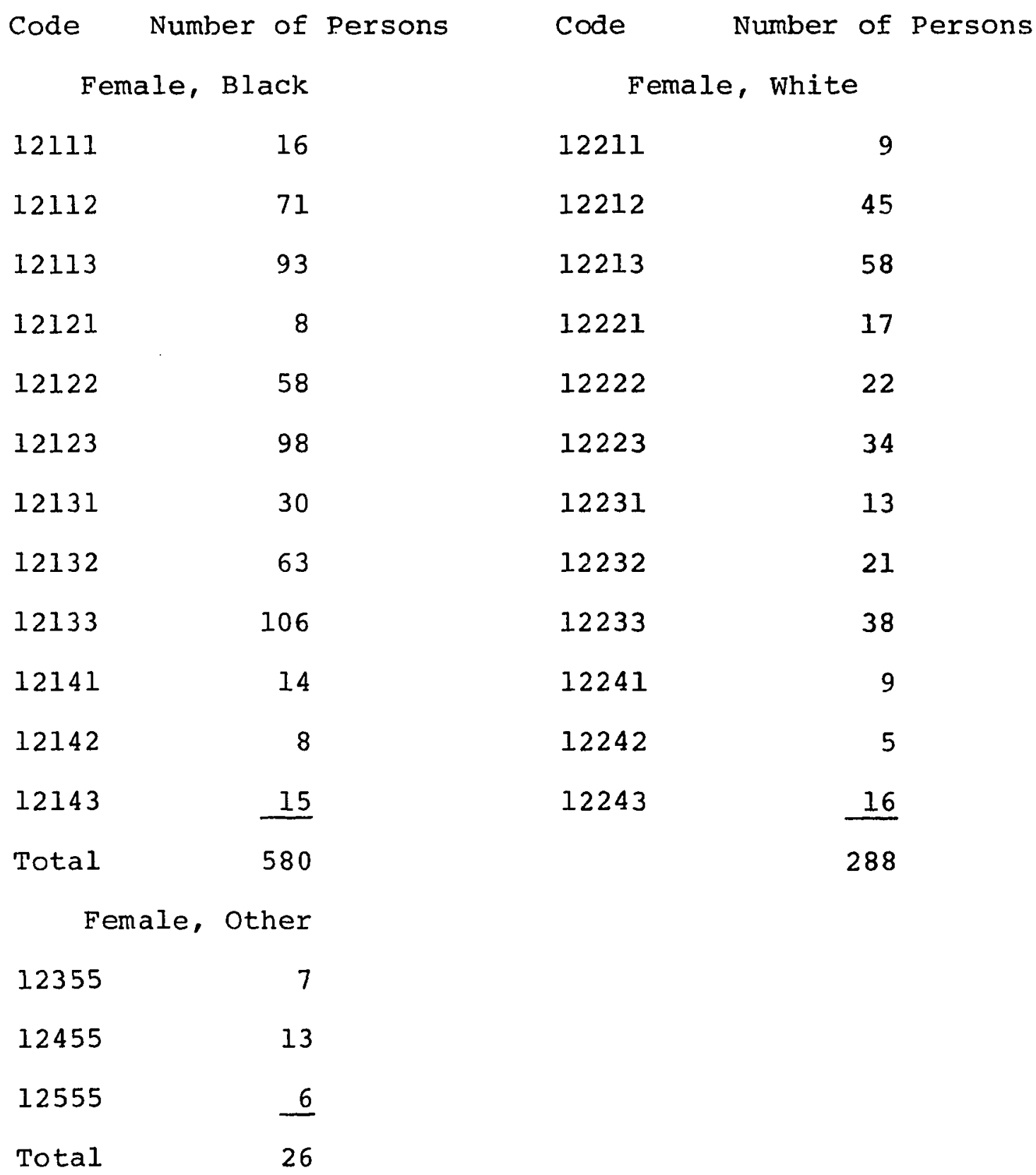


TABLE VII (Continued)

FREQUENCY BY CODED CELL - CONTROL GROUP

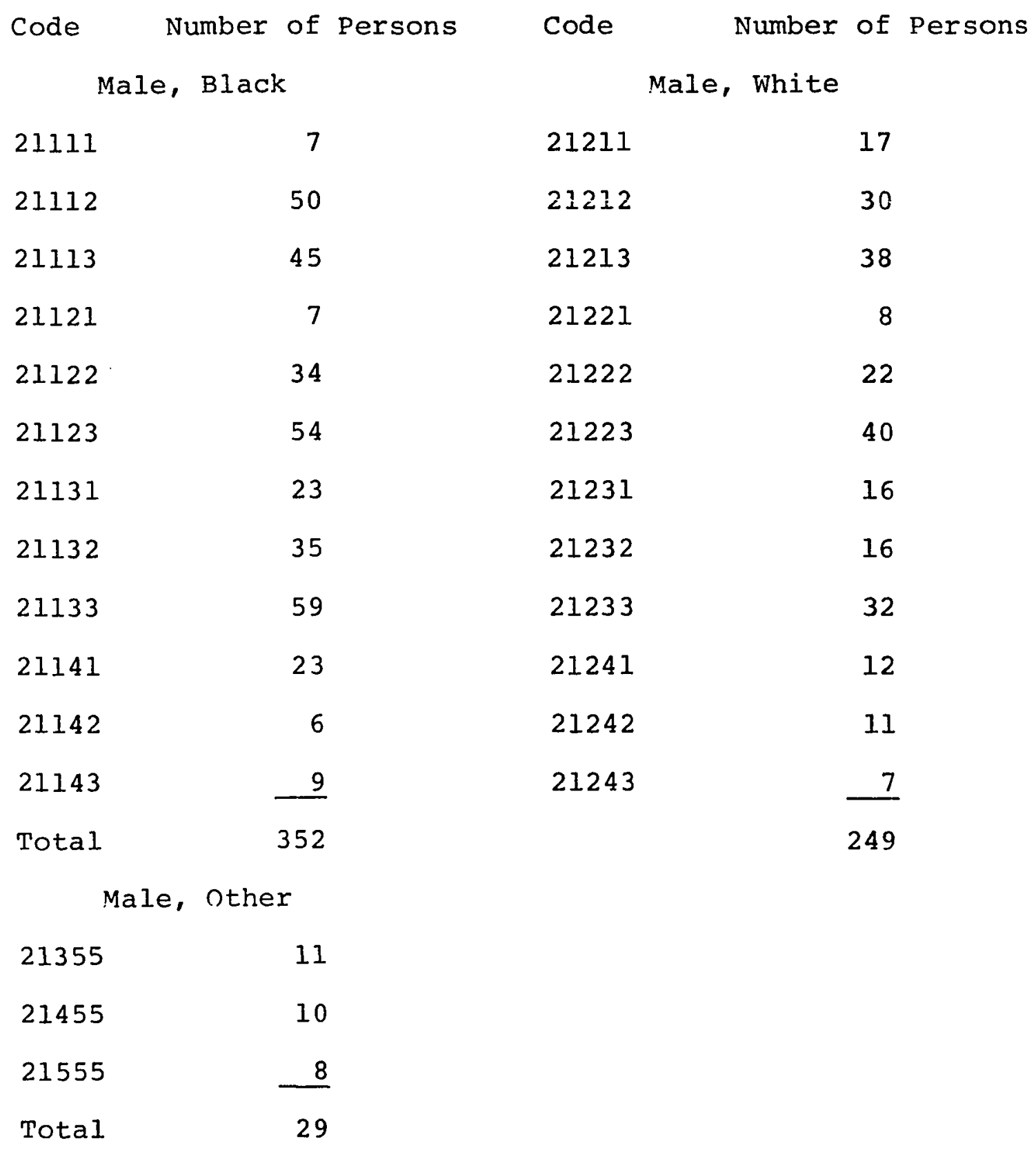


TABLE VII (Continued)

FREQUENCY BY CODED CELL - CONTROL GROUP

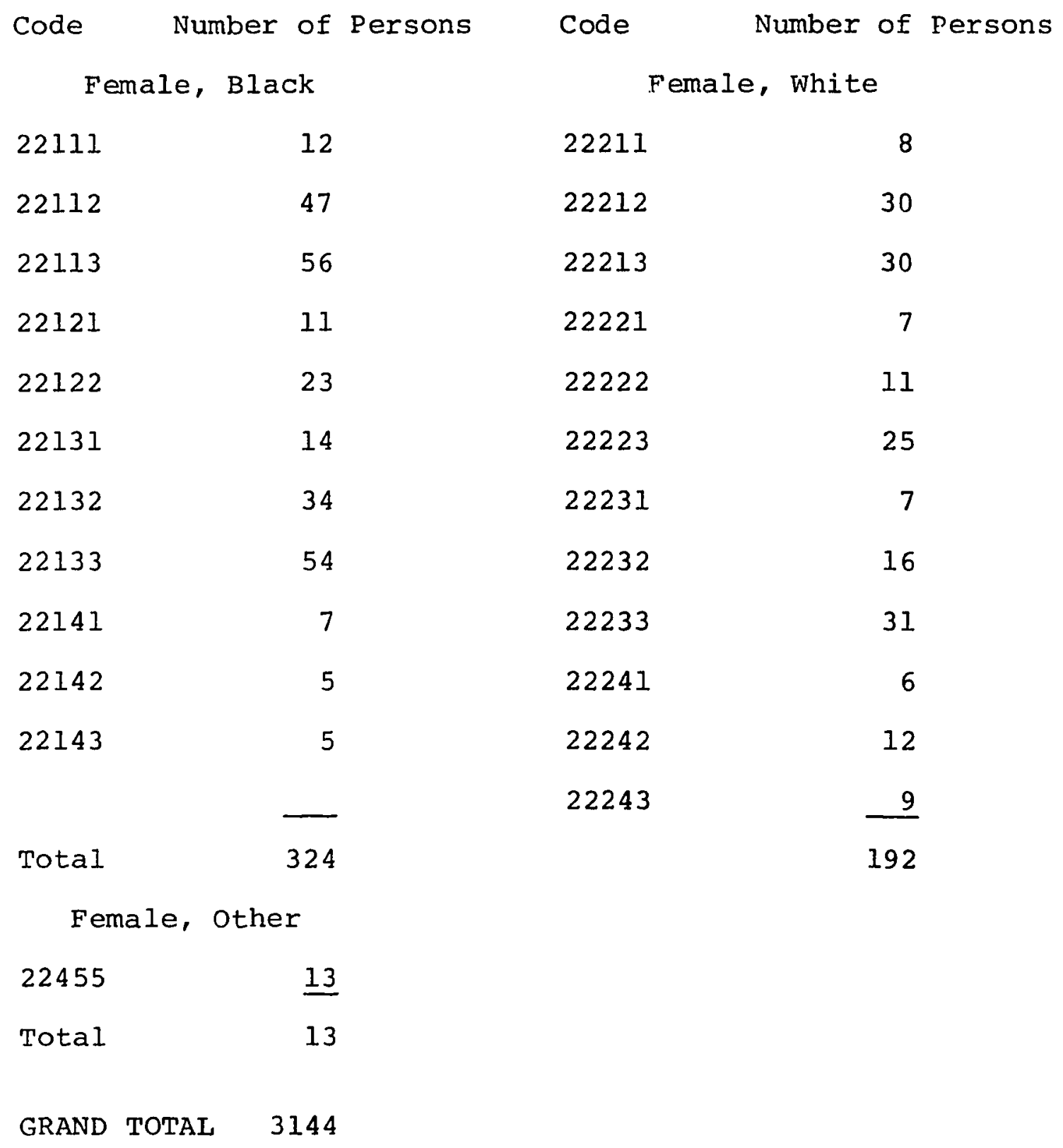


After considering the small number of persons in the Mexican-American, American Indian, and other cells, and the increased complexity introduced by a five-level variable versus a two-level variable, these cells were eliminated from the study. A two-level variable for race - Black and White - was used in the final analysis. A number of the frequencies in the coded cells are low, particularly in the control group. All available records at PCEP were utilized in compiling the control group. Three possible alternatives were considered: (1) Increasing the number of persons in the cell by the process of estimation; (2) Aggregating the cells - increasing the frequencies in the involved cells by eliminating one of the levels of one of the variables; and (3) analyzing the data as reported and noting the possible unreliability introduced by the small cell size. The first alternative was rejected because of the complexity of the task and the questionable validity of the estimated result. The second alternative was also rejected because of the loss of information and the apparent importance of the different levels of the variables as defined. For instance, the cells representing persons 45 years of age and over have low frequencies. The mean earnings of coded cells 12241 and 12231 are respectively $\$ 961$ and $\$ 2286$. Persons over 45 years of age in every category earned appreciably less income than did those in other categories. The aggregation of the categories did not appear to benefit the research. 
Instead, the low cell sizes in certain categories are noted, and less reliance should be placed on the conclusions derived from these cells.

The original research design included a second code including the variables year treated, type of training received, length of training, and years of education. The earnings information for the second code was reported by the SSA. The author intended to compare earnings in 1972 and 1973 as well as median earnings and mean earnings in the different years reported. Unfortunately, the computer tape prepared by the SSA could not be utilized. After investing a considerable amount of time in an unsuccessful attempt to retrieve data from the SSA tape, the decision was made to discard the tape. This decision meant that all data to be utilized in the analysis had to be keypunched onto computer cards from the over four-hundred page computer printout provided by the SSA. Constraints on time and funds limited the amount of information which could be keypunched. The decision was made to perform the analysis on the first code which contained both the participants and the control group and included larger cell frequencies. Mean earnings which reflect more accurately the possible total lifetime stream of earnings over time, was chosen as the earnings measure. The study is limited to earnings in the year 1973. 
ANALYSIS OF THE DATA

The statistical technique chosen for analysis of the data was the analysis of variance. Multiple regression analysis was rejected due to the large number of dummy variables which would have to be included in the equation. The general purpose of Analysis of Variance is to determine which factors of an experiment have noteworthy effects on the scores, and to provide quantitative information about the relative importance of different factors and their levels. The Analysis of Variance is utilized in this research to determine whether the factors previously described as the independent variables have noteworthy effects on the incomes of the persons in this study. The primary interest is focused on the effects of participation in the PCEP on income. The different levels of the five factors and their effects on income levels are also of interest in that they aid in determining which particular categories of persons benefit or do not benefit from participation in the PCEP or similar programs.

Analysis of Variance (ANOVA) is based on the assumptions that there are equal scores per condition, the distribution of the scores within a condition conforms to the normal distribution, and the assumption of homogeneity of variance. Actually, it has been demonstrated by Norton that the F-test, which is the test of significance used in 
ANOVA, is fairly robust with respect to heterogeneity of variance of normal distributions, and also with respect to simultaneous failures of both normality and heterogeneity of variance. The Analysis of Variance computer program for this research was performed using the original data reported by the SSA as well as two standard score transformations. There was no significant difference in the results of the analysis.

The Biomed program, Analysis of Variance for Factorial Design, was utilized in the analysis of the data. The research design is described as a $2 \times 2 \times 2 \times 4 \times 3$ factoral experiment. All five factors are considered fixed factors. The Analysis of Variance for Factorial Design program provided the following output:

(1) Analysis-of-variance table and the grand mean.

(2) A breakdown of the sums of squares into orthogonal polynomial components for four main effects and all of their first order interactions.

(3) Main effects and first order interactions for the factors specified in (2).

(4) Cell and marginal means.

To obtain a denominator to be utilized in the FTest for Significance, the fifth level interactions were pooled with the computed residual term. Tukey's Test for Nonadditivity was performed and supported the hypothesis 
that the components for the fifth level interaction are homogeneous. There was no reason to reject the hypothesis of additivity, and therefore the pooling of the fifth level interactions provides an estimate of experimental error.

\section{F-Tests for Interaction}

The F-Test for Interaction was performed prior to the F-Test for Main Effects since the existence of interaction between two or more factors affects the influence of the main effects. For example, two factors such as participation in the PCEP and race of the individual may interact to produce an effect which is different than the main effect of treatment or race measured individually.

The interactions found to be significant using the FTest for interaction for the fixed effects model are shown in Table VIII. 
TABLE VIII

F-TESTS FOR INTERACTION FOR FIXED EFFECTS MODEL

\begin{tabular}{|c|c|c|c|c|}
\hline $\mathrm{df}_{1}, \mathrm{df}$ & Sources & $\mathrm{F}_{95}$ & $\begin{array}{l}\mathrm{df}_{1}, 28 \\
F_{99}\end{array}$ & $\begin{array}{l}F_{99.9}\end{array}$ \\
\hline 1,29 & $\begin{array}{l}\text { TR, MS } \\
\text { error }\end{array}$ & 4.20 & 7.64 & 13.5 \\
\hline 3,29 & $\begin{array}{l}\text { SA, MS } \\
\text { TRA, MS error } \\
\text { error }\end{array}$ & 2.95 & 4.57 & 7.19 \\
\hline
\end{tabular}

INTERACTIONS SIGNIFICANT AT $\mathrm{p}<.05$

Treatment, Race $\quad F_{(1,29)}=5.71$

Treatment, Race, Age $F_{(3,29)}=3.47$

INTERACTIONS SIGNIFICANT AT p<.001

Sex, Age $\quad F_{(1,29)}=8.69$

Although the F-Test for interaction indicated that four of the five factors had significant interaction with one or more other factors, the F-Test for Main Effects was performed for all five factors. All Main Effects were found to be significant at the .10 level or higher. Education, the factor which had no significant interaction with other factors, is significant at the .001 level. 
TABLE IX

F-TESTS FOR MAIN EFFECTS FOR FIXED EFFECTS MODEL

\begin{tabular}{|c|c|c|c|c|c|}
\hline $\mathrm{df}_{1}, \mathrm{df}$ & Sources & $F_{90}$ & ${ }_{95}$ & ${ }_{9}^{d f}{ }_{99}$ & $F_{99.9}$ \\
\hline 1,29 & $\begin{array}{l}\text { Treatment } \\
\text { Sex MS } \\
\text { Race error }\end{array}$ & 2.89 & 4.20 & 7.64 & 13.5 \\
\hline 2,29 & $\begin{array}{l}\text { Education } \\
\text { MS } \\
\quad \text { error }\end{array}$ & 2.50 & 3.34 & 5.45 & 8.93 \\
\hline 3,29 & $\begin{array}{l}\text { Age, MS } \\
\text { error }\end{array}$ & 2.29 & 2.95 & 4.57 & 7.19 \\
\hline
\end{tabular}

Main Effects Significant at $p<.10$

Treatment $F_{(1,29)}=3.49$

Main Effects Significant at $p<.01$

Race

$$
F_{(1,29)}=11.86
$$

Main Effects Significant at $p<.001$

$\begin{array}{ll}\text { Sex } & F_{(1,29)}=35.47 \\ \text { Age } & F_{(3,29)}=14.08 \\ \text { Education } & F_{(2.29)}=12.49\end{array}$


In spite of the significant interactions between Treatment and Race; Treatment, Race, and Age, and Sex and Age, all main effects except Treatment are significant at the .01 level or better. Because of the significant interactions, care must be taken in interpreting the main effects due to Treatment, Race, Sex, and Age. The manner in which the different levels of the factors with significant interactions are related is most readily shown by the profiles of the simple effects for the factors at different levels. These profiles are drawn in Figures 3-8. Data for these profiles are obtained from the ANOVA summary tables. Figures 3-5 represent the profiles of the means at different levels of the factors Treatment, Race, and Age. The notations for the levels follows the code given in Table VII. For example $T$ stands for participation in the PCEP, $R$ stands for Blacks, etc. Generally, if two profiles have the same shape (i.e., are parallel) all simple interactions are zero. The profiles of a three-factor interaction, such as shown in Figures 3-5 imply that the third level interaction is equal to zero when (1) the profiles of the two-factor means are parallel within each level of the third factor or when (2) the pattern of profiles for the two-factor means is geometrically similar to the pattern for the combined levels. A three-factor interaction may be nonzero while the two-factor interaction is zero. The TA profiles for the combined levels of Race, for example are nearly parallel and 


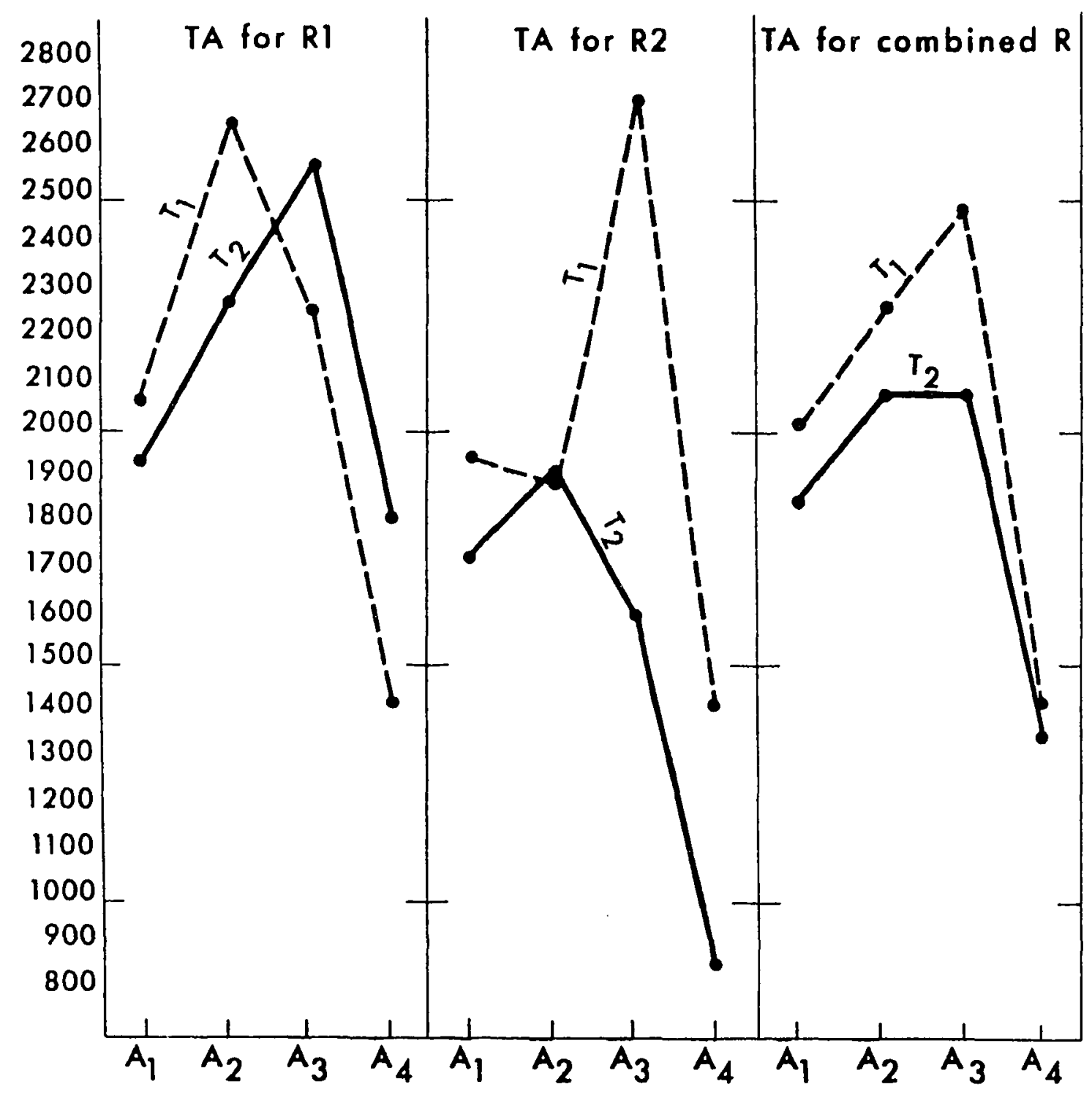

Figure 3: Mean profiles for treatment and age by race 


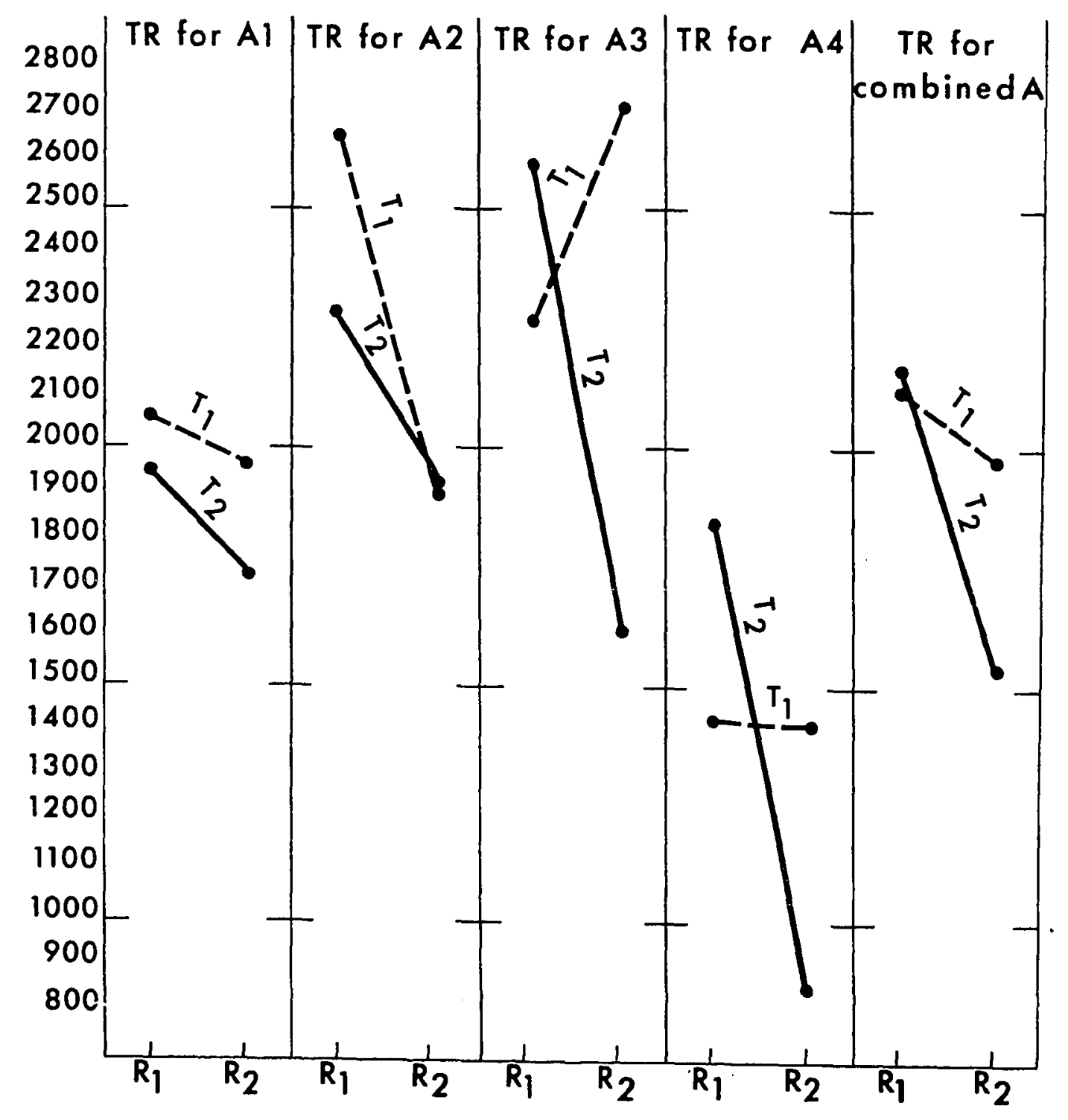

Figure 4: Mean profiles for treatment and race by age 


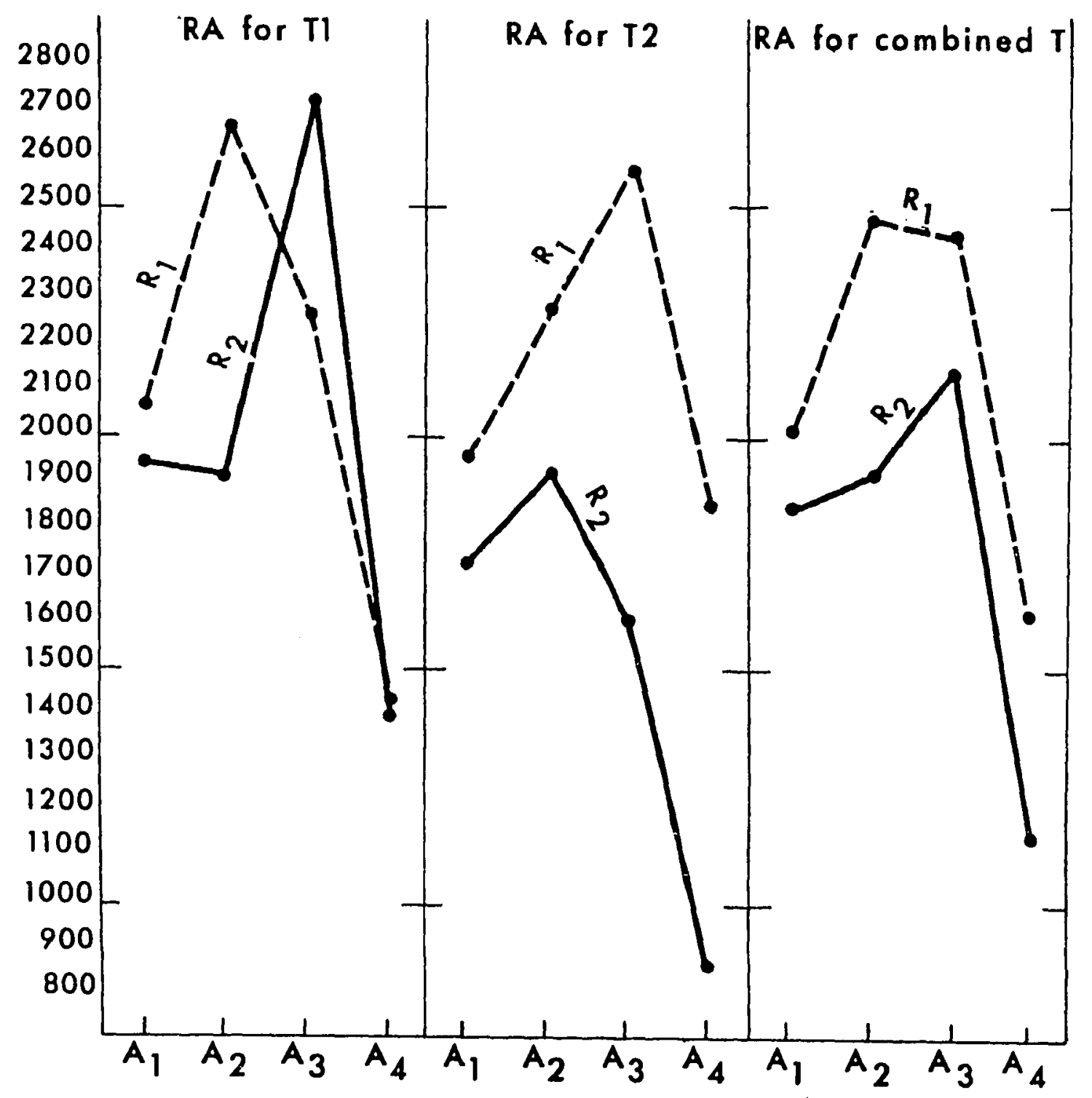

Figure 5: Mean profiles for race and age by treatment 


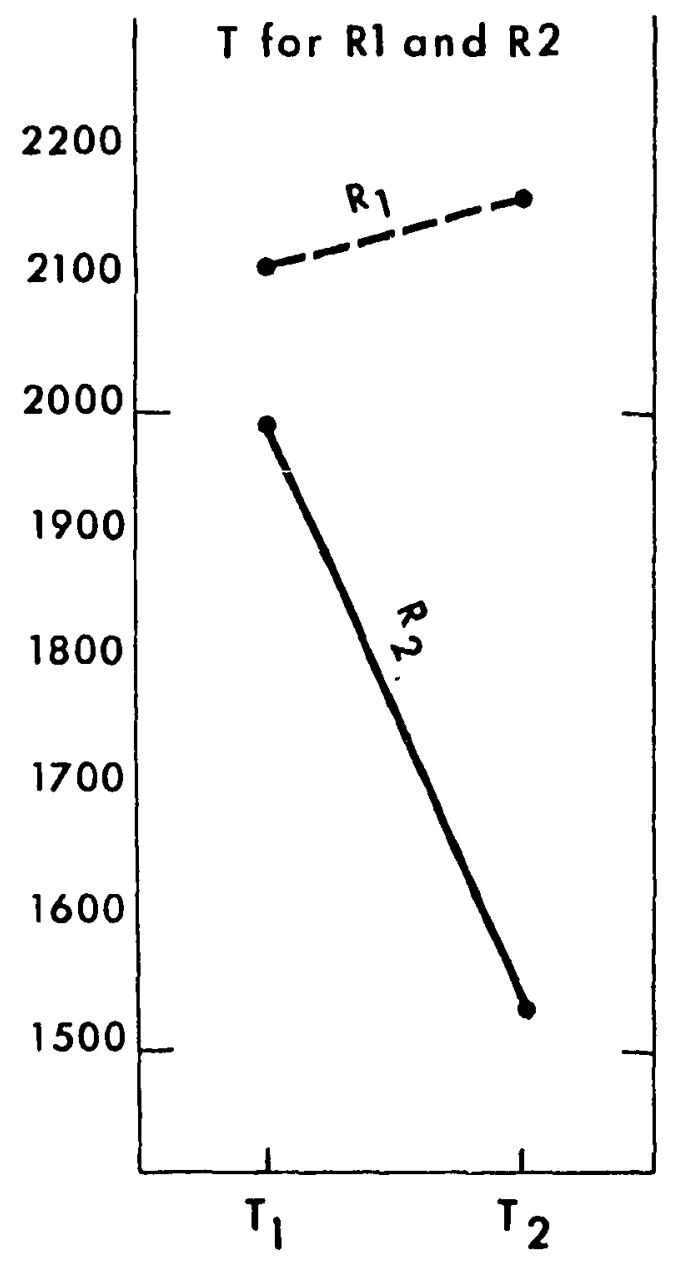

Figure 6: Mean profiles for treatment and race 


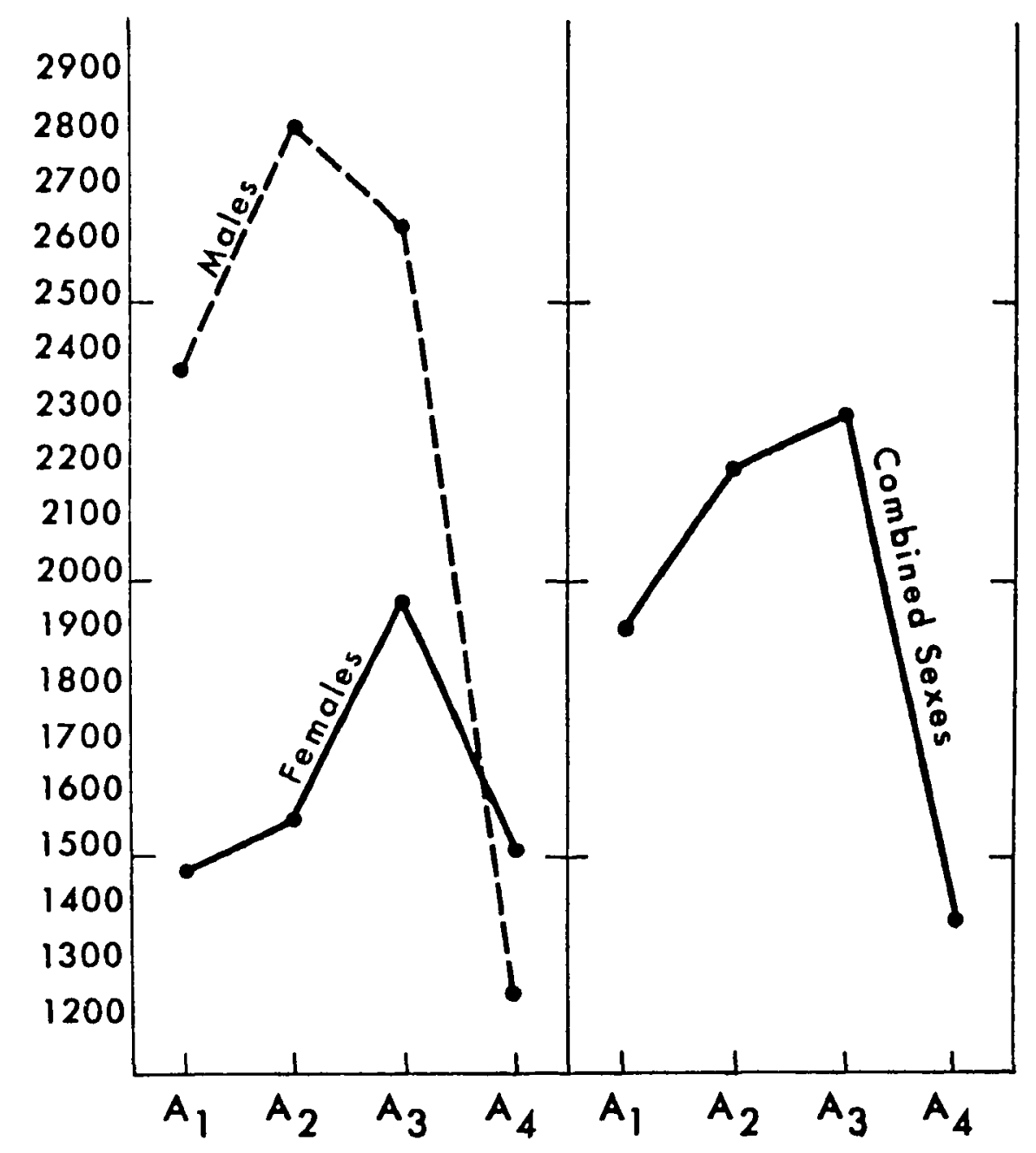

Figure 7: Mean profiles for sex and age 


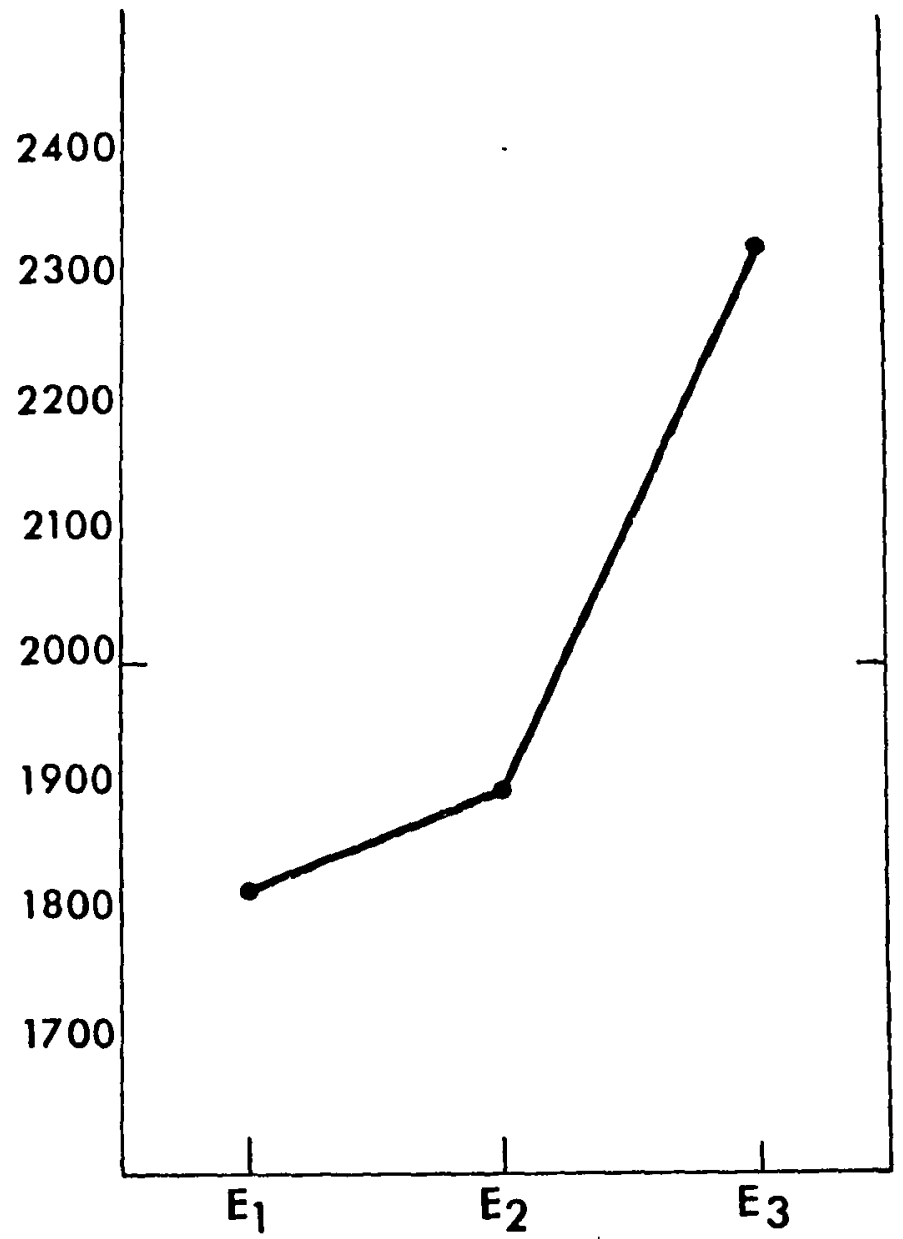

Figure 8: Mean profile for education 
do not cross. Thus, the interaction between Treatment and Age may be equal to zero. In fact the interaction was not significant. Figure 4 represents the three level interaction with the profiles on the far right representing Treatment and Race for Combined Ages. The profiles are not parallel and cross each other. This implies that the twofactor interaction for Treatment and Race is not equal to zero. The interaction was significant. The interaction between Race and Age was also not significant at the .05 level. The interaction between Treatment and Race is presented in Figure 6. The profiles are not parallel and the two-factor interaction was significant at the .05 level. The interaction between Sex and Age is presented in Figure 7. The profiles are not parallel and cross each other. The interaction was significant at the .001 level.

In addition to providing information on interactions, the profiles in Figures $3-7$ indicate the possible differences between the different levels of one factor and its effects on the different levels of another factor. For instance Figure 6 represents the profiles of the two factors, Treatment and Race. The profiles appear to indicate that Treatment has a beneficial income effect on Whites and a possibly small negative effect on Blacks. Examination of the profiles in other figures provides further information and indications of possible relationships which require additional testing. 
It may appear that the main use of analysis of variance in this research is to generate a number of $F$ statistics on the data. However, the author considers the generation of $\mathrm{F}$ tests as only a small part of the advantages gained from the use of ANOVA. The important feature of ANOVA for this study is that it permits the separation of all the potential information in the data into distinct and nonoverlapping portions, each reflecting only certain aspects of the experiment. The mechanics of the analysis of variance allow for the arrangement and the summarization of the data in nonredundant ways in order to make decisions as to whether effects exist and to estimate how large or important these effects may be. The analysis of variance allows the researcher to "pull apart" the factors that contribute to variation and to examine the particular, meaningful, aspects of the data. The large number of $F$ tests which were performed greatly increased the probability that at least one of the tests showed spurious significance at the .05 level. The presence of the same mean square for error in the denominator of the test creates some statistical dependency among the various $F$ tests, and consequently increases the probability of spurious results. For this reason the results of the $F$ tests need to be considered in conjunction with the pattern and interpretability of the results in order to form a more reasonable basis for evaluation of the 107 data. 


\section{A Posteriori Tests}

Four variables, not including Treatment, were included among the independent variables due to their proven association with income in the United States. The research was designed with the intention of testing the five independent variables, with their twenty-nine different levels, to see which turned out to be significant in affecting the income levels of persons included in this study. Such tests are called a posteriori or post hoc contrasts. It is recognized that such a large number of a posteriori tests capitalize on the chance differences that happen to be large for this particular study due to sampling variability. To lessen the possibility of Type I errors the significance level accepted for contrast testing is set at .01 , rather than the .05 level accepted for main and interaction effects. The test chosen for the contrasts is the Least Significant Difference Test.

\section{$\underline{\text { Sex and Age }}$}

Sex and Age demonstrated a significant interaction of .001 . The profiles representing the interaction were not parallel and crossed between Age and Age. The Least Significant Difference Test demonstrated at the .01 level that males matched to females of the same age bracket at all ages except 45 years and over earned significantly higher incomes than did females. Females $21-25$ and 26-44 years 
earned significantly more than males 45 and over. Males ages $0-20,21-25$ and $26-44$ years earned significantly higher incomes than females in any age category. There is no significant difference between the incomes of females age 45 and over and males ages 45 and over. There is no significant difference between males age 21-25 and males age 26-44 years. Males ages 21-25 years do earn significantly more than males aged $0-20$ years. Males $0-20$ years of age, 21-25, and 26-44 years of age, all earn significantly more than males aged 45 and over. Females ages 26-44 years earn significantly more than do females ages $0-20$ and 21-25 years. Thus, it would appear that males aged 0-44 years earn significantly more than females of that age group. Up until age 44 both groups appear to have increased earnings with age, or at least to have no significant decrease in income as age increases. Apparently, discrimination by sex in the labor force, and perhaps within the training programs of the PCEP, resulted in significant differences between male and female earnings in all age groups between 0-44 years. Sex, rather than age up to age 45 , appears to be the most important factor influencing incomes in the interaction between Sex and Age.

Treatment and Race

The interaction between Treatment and Race was significant at the .05 level. The profiles between Treatment 
and Race were not parallel. The Least Significant Difference test demonstrated that at the .01 level of significance there existed no significant difference between Blacks who participated in PCEP and Blacks in the control group. There was a significant difference between whites who participated in PCEP and Whites in the control group. But, there was also a significant difference between the Black and the White control group with the Black group earning significantly more than the white group. There was no significant difference between the Whites participating in PCEP and the Blacks who did not participate. This suggests that the Blacks who chose not to enter the program for unknown reasons may have been superior in terms of labor force participation potential, than the Whites who chose not to enter the program. The Blacks who participated in the PCEP were earning significantly better incomes than the Whites in the control group. The difference between the white and Black participants was not significant. Two different explanations for the differences between incomes by race are considered. The finding that Black participants as a whole and within different levels of different factors appear to earn significantly more than white participants suggests that there is a difference between white applicants and Whites in the larger labor force. The labor market discrimination against Blacks may result in Blacks with superior labor market potential requiring the services of a 
manpower program to gain entrance to employment opportunities. Whites, who experience little or. no entrance barriers to employment, can be expected to obtain jobs more readily without manpower program assistance. The White applicants and participants in manpower programs may lack crucial job skills or sufficient motivation to obtain and hold a job. The White participant and control groups may be comparable and the White groups may in fact be more disadvantaged than the Black groups. Treatment may significantly benefit the White group more than the Black group. Alternatively, for unknown reasons, the particular white group who applied and did not participate in the PCEP may have a different labor market potential than the white group who participated in the PCEP. Although the Black control group does appear to be equal to the Black participant group, the white groups may not be comparable. If this is the case, the study is biased in favor of the white participants. The interaction between Treatment and Race appears to be a function of a difference in incomes between races in the control group rather than an influence of the PCEP.

\section{Treatment, Age, and Race}

The interaction between Treatment, Race and Age was significant at the .05 level. The findings suggest that the introduction of the age factor does influence the interaction between treatment and race. Although the two factor 
interaction demonstrated no significant difference in income between Black and White participants as a whole, there do exist significant differences between both the participant groups and the non-participant groups and the control groups at different age levels.

Within the first age level, 0-20 years, the only significant difference was between treated Blacks and untreated Whites. Blacks participating in the PCEP did not earn significantly more than Blacks in the control group. There was no significant difference between white participants and Black participants, the White control group, or the Black control group.

Black participants in the second age level, 21-25 years, earned the highest income received by Blacks in any group in the study. There exists a significant difference between Blacks participating in the PCEP age $21-25$ and all other groups with the exceptions of White participants age 26-44, and untreated Blacks ages 26-44 years. Blacks entering the PCEP between ages 21-25 years did significantly better than similar Blacks of the same age who did not enter the program.

Between the ages of 26-44 years the highest incomes were earned by Whites participating in the PCEP and Blacks in the control group. There exists no significant difference between the incomes of these two groups, or between their incomes and the incomes of Blacks ages 21-25. There 
is a significant difference between white and Black participants ages 26-44, and the Black control group aged 26-44 earned significantly more than the Black participants of the same ages. Although the Black participants ages 26-44 years did earn significantly less than the Black control group, the White participant group of the same age, and treated Blacks ages 21-25 years, they did earn significantly more than white participants and control groups ages 0-20 and ages 21-25, and the Black control group ages 0-20 years. The white control group ages 26-44 did significantly worse than every other group in the study except the white control group 45 years and over.

With the exception of the Black control group, persons aged 45 years and over earned significantly less than every other group except the White control group aged 26-44 years. The Black control group ages 45 and over earned significantly more than one group, the white control group of the same age. Both the Black and the white control groups aged 45 and over contained small cell frequencies and are not considered representative of a larger population. The participant groups did contain larger cell frequencies, and their income levels, which were significantly lower than those of other groups in the study, do suggest that participation in manpower programs is not beneficial for persons 45 years and over. 
The profiles in Figure 4 representing Treatment and Age for combined races suggests that with race not considered, those participating in the PCEP continue to have increased earnings as age increases up to age 44 years. There exists a significant difference between participants ages 26-44 and the control group of the same age. This difference for combined races is apparently due to the inexplicably low earnings of the white control groups of this age. The participant group age 26-44 also earned significantly more than did the untreated groups of all ages and the treated group ages $0-20$ years.

\section{Education}

The F-test for interaction demonstrated no significant interaction between education and any of the other four independent variables. The F-test for main effects resulted in $F=12.49$ for education which is significant at the .001 level. Education has a significant effect on the incomes of persons involved in the study. At the .01 level the tests for simple effects found no significant difference between persons with 1-9 years of education and persons with 10-11 years of education. There exists a significant difference between persons with 12 years of education and over and persons with 1-9 years of education. A significant difference was also found between persons with 12 years of education and over and persons with 10-11 years of education. The large difference in earnings between persons with 
a high school education and persons with less than a high school education on application to the PCEP is present in all groups and within all levels except for those 45 years of age and over. This finding suggests that regardless of treatment, age (with the exception of those 45 years and over), sex, and race - persons with a high school education prior to application for the PCEP will earn significantly more than persons without a high school degree. The possible significance of this finding will be explored in Chapter VI.

Although no significant interaction was demonstrated between education and the other independent variables, significant differences do exist between the different levels of the four factors and education.

The following findings are not considered statistically although the LSD results are reported. They are included to present more information on possible relationships between the groups in the study.

Treatment and Education

Both participants and nonparticipants with a high school education or better earned significantly more than did all other groups. There was no significant difference between participants with a high school education and nonparticipants with a high school education. Participants with 1-9 years of education did earn significantly more than 
did the control group with a similar education. There was no significant difference between the participants and the nonparticipants with 10-11 years of education. Participants with 10-11 years of education did earn significantly more than nonparticipants with $1-9$ years of education. These findings suggest that priticipation in the PCEP, not considering other factors, is of more significant benefit to persons with 1-9 years of education.

\section{Race and Education}

Blacks with a high school education did significantly better than all other groups including whites with a high school education. Whites with a high school education did not earn significantly more than Blacks with 1-9 years of education, Blacks with 10 and 11 years of education, and Whites with 10-11 years of education. Whites with a high school education earned significantly more than only one group, Whites with $1-9$ years of education.

The differences notes above between whites and Blacks with different educational levels were influenced by the poor performance of the white control group. Inclusion of the factor Treatment alters the findings. Black participants and nonparticipants who had completed high school continued to demonstrate significantly higher income levels than did any other group. There was no significant difference between the participant and nonparticipant Black groups with 12 years of education. Treated Whites with 12 years of 
education earned significantly more than all other groups with the exception of treated Whites with 10-11 years education, and treated and untreated Blacks with 12 years education. Treated Whites with 1-9 years of education and 10-11 years of education earned significantly more than the White control groups with the same education, but not more than the Black control groups with similar educational levels.

Sex, Education and Treatment

Treated males at all educational levels earned significantly more than did treated females with similar educations. Treated males with 12 years of education earned significantly more than all treated groups. Treated females with 12 years of education did not earn significantly more than treated males with 1-9, and 10-11 years of education. Treated females with 12 years of education did earn significantly more than treated females with 1-9, and 10-11 years of education. Male participants with 1-9 years of education earned significantly more than similar nonparticipants. Within this group treated white males earned significantly more than treated male Blacks and untreated Whites. If treated Black males and treated White males are compared only to the untreated Black control group with 1-9 years education, there is no significant difference in incomes between the groups. Untreated Black males with 
10-11 years of education earned significantly more than treated Black males and untreated white males with similar educations. Treated White males with 10-11 years of education earned significantly more than similar treated Blacks. There was no significant difference between the treated Whites of this group and the untreated Blacks. With combined races there was no significant difference between treated and untreated males with 10-11 years of education. Treated Black males with 12 years of education earned significantly more than treated and untreated white males with similar education. There was no significant difference between treated and untreated Black males with 12 years of education, but untreated Black males of this group earned significantly more than similar treated white males. There was no significant difference between the treated and the untreated group with combined races for males with 12 years of education. Untreated males earned significantly more than untreated females at every level of education. Untreated Black females earned significantly more than untreated White females at every level of education. Treated Black females with 1-9 years of education earned significantly more than treated and untreated white females with 1-9 and 10-11 years of education. Treated Black females with 1-9 years of education did not earn significantly more than untreated Black females of similar education. Treated White females did earn significantly more than untreated 
White females with $1-9$ years of education. Treated White and Black females did not earn significantly more than untreated Black females with 10-11 years of education, but both treated groups earned more than the similar untreated White females. With combined races treated females with 10-11 years of education earned more than untreated females with similar education. Untreated white females with 12 years of education earned significantly less than treated White females, and treated and untreated Black females with 12 years of education. Treated and untreated Black females with 12 years of education earned significantly more than treated White females with similar education, but there was no significant difference between the treated and untreated Black females with 12 years of education. With combined races there is no significant difference in income between treated and untreated females with 12 years of education. Untreated Black females, treated Black females, and treated White females with 12 years of education earned significantly more than females in every other female group.

Age and Education

All age and education groups except those 45 years and over earned significantly more than did the group aged 0-20 years with $1-9$ years of education. With the forementioned exception, there was no significant difference in earnings between persons aged $0-44$ years with $1-9$ years of 
education and 10-11 years of education. High school graduates aged 0-44 earned significantly more than all other education groups. There was no significant difference between the incomes of high school graduates at different age levels. All persons ages 45 and over did significantly worse than all other age and education groups with the exception of persons 0-20 with 1-9 years of education.

\section{ANALYSIS WITH ZERO EARNERS AND THOSE 45 YEARS AND OVER EXCLUDED}

The analysis presented in the previous pages included all persons including persons reported as having no earnings during the year 1973. The author considers that all persons included in the study regardless of their present earning levels should be included in the analysis. But, because of the nonuniversality of the social security data and the possibility according to Social security sources, that at least 10 percent of the persons reported as having zero earnings may in fact have been working in jobs not covered by Social security, a brief analysis of persons in the study reported as earning more than zero dollars is included. The groups ages 45 years and over were excluded due to the small cell size which remained after zero earners were dropped. The Analysis of Variance with zero earners and those 45 years and over excluded resulted in different findings. 
The F-test for interactions showed no interactions significant at the .05 level between the variables treatment, race, sex, age, and education. The F-test for Main Effects is presented in Table $\mathrm{x}$. The two Main Efrects found to be significant were education and sex. Treatment, race, and age were not significant at the .05 level. Thus, the main variables affecting the incomes of the persons involved in this portion of the study are sex and education. Sex appears to have the greatest effect on earnings, and examination of the incomes by group demonstrates a large difference in earnings between males and females.

A study performed by the Olympus Research Corporation 108 on the Total Impact of Manpower Programs found that both pre- and post-wage rates were higher for males than females. However, because of their lower starting points the females tended to experience greater wage and income increases if employed. 109 The study which utilized interviews to obtain their findings was also able to determine whether participants chose to seek employment following training. Olympus Research found that in the WIN programs, which included 70-85 percent females, relatively few of its welfare mothers chose to seek employment following enrollment. ${ }^{110}$ The research design of this study made it impossible to detect persons actively seeking employment from those who chose to not enter the labor market following training or application 
TABLE X

ZERO EARNERS AND PERSONS 45 AND OVER EXCLUDED: F-TESTS FOR MAIN EFFECTS FOR FIXED EFFECTS MODEL

\begin{tabular}{lllll}
$\mathrm{df}_{1}, \mathrm{df}{ }_{2}$ & Sources & F & F & F \\
\hline 1,20 & Sex, MS & 95 & 99 & 99.9 \\
2,20 & $\begin{array}{c}\text { Error } \\
\text { Education, MS } \\
\text { Error }\end{array}$ & 3.49 & 5.85 & 14.8 \\
\hline
\end{tabular}

Main Effects Significant at $p<05$

Education $F(2,20)=4.00$

Main Effects Significant at $p<.001$

Sex $\quad F(1,20)=15.5$ 
to the program. But, the low mean earnings for females and the high percentage of female zero earners relative to males, suggests that a higher percentage of females than males in this study may have chosen not to seek employment. The olympus study also found that clerical training resulted in below average wage rates, but considerable employment stability. The director of the PCEP program indicated that many of the women participants in the PCEP program receiving skill training were enrolled in clerical courses. This may also have influenced female participant income levels. The mean earnings by sex, race, and treatment indicate that Black male nonparticipants earned $\$ 343$ dollars more in 1973 than did Black male participants. When age and education are included Black male participants ages 0-20 years with 10-11 and 12 years of education earned slightly more than did similar nonparticipants. Black male participants aged 26-44 years with 12 years of education or more earned $\$ 1.91$ more dollars in 1973 than did similar nonparticipants. At other age and education levels Black male nonparticipants earned more than Black male participants in the PCEP. White male participants earned $\$ 521$ more in 1973 than did White males in the control group. When age and education are included, the only white male nonparticipant groups with large cell sizes to earn more than the participant White males were white males $0-20$ years of age with $10-11$ 
TABLE XI

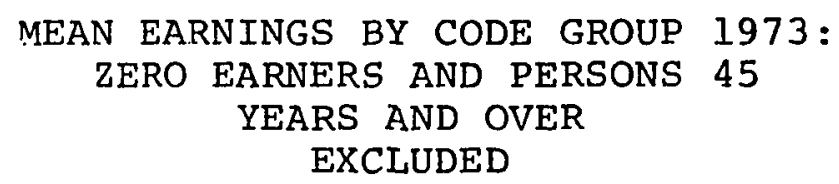

\begin{tabular}{|c|c|c|c|c|}
\hline 11111 & $\$ 2262 *$ & 21111 & $\$ 3015 *$ & $\$ 753$ \\
\hline 11112 & $\$ 2598$ & 21112 & $\$ 2560$ & $\$ 38$ \\
\hline 11113 & $\$ 3686$ & 21113 & $\$ 3531$ & $\$ 155$ \\
\hline 11121 & $\$ 4004$ & 21121 & $\$ 5208 *$ & $\$ 1204$ \\
\hline 11122 & $\$ 3295$ & 21122 & $\$ 4027$ & $\$ 732$ \\
\hline 11123 & $\$ 4183$ & 21123 & $\$ 4415$ & $\$ 232$ \\
\hline 11131 & $\$ 3219$ & 21131 & $\$ 3359$ & $\$ 1.40$ \\
\hline 11132 & $\$ 3674$ & 21132 & $\$ 4317$ & $\$ 643$ \\
\hline 11133 & $\$ 4371$ & 21133 & $\$ 4180$ & $\$ 191$ \\
\hline 11211 & $\$ 2985$ & 21211 & $\$ 1043$ & $\$ 1942$ \\
\hline 11212 & $\$ 2848$ & 21212 & $\$ 3505$ & $\$ 657$ \\
\hline 11213 & $\$ 3278$ & 21213 & $\$ 3248$ & $\$ 30$ \\
\hline 11221 & $\$ 2793$ & 21221 & $\$ 3326 *$ & $\$ 533$ \\
\hline 11222 & $\$ 3861$ & 21222 & $\$ 3192$ & $\$ 669$ \\
\hline 11233 & $\$ 3066$ & 21223 & $\$ 2706$ & $\$ 360$ \\
\hline 11231 & $\$ 3139$ & 21231 & $\$ 2045$ & $\$ 1094$ \\
\hline 11232 & $\$ 4709$ & 21232 & $\$ 2280$ & $\$ 2429$ \\
\hline 11233 & $\$ 4529$ & 21233 & $\$ 4291$ & $\$ 288$ \\
\hline
\end{tabular}

* Indicates cell frequency less than 10 Underlined difference indicates control group earned more than participant 
TABLE XI (Continued)

Code
Partici
FEMALES

\begin{tabular}{|c|c|c|c|c|}
\hline 12111 & $\$ 2892$ & 22111 & $\$ 1848 *$ & $\$ 1044$ \\
\hline 12112 & $\$ 1824$ & 22112 & $\$ 1471$ & $\$ 353$ \\
\hline 12113 & $\$ 3191$ & 22113 & $\$ 3539$ & $\$ 348$ \\
\hline 12121 & $\$ 3199 *$ & 22121 & $\$ 477 *$ & $\$ 2722$ \\
\hline 12122 & $\$ 2295$ & 22122 & $\$ 2050$ & $\$ 245$ \\
\hline 12123 & $\$ 3579$ & 22123 & $\$ 3719$ & $\$ 140$ \\
\hline 12131 & $\$ 2164$ & 22131 & $\$ 3865$ & $\$ 1701$ \\
\hline 12132 & $\$ 2240$ & 22132 & $\$ 2483$ & $\$ 243$ \\
\hline 12133 & $\$ 3040$ & 22133 & $\$ 3466$ & $\$ 426$ \\
\hline 12211 & $\$ 1357 *$ & 22211 & $\$ 773 *$ & $\$ 584$ \\
\hline 12212 & $\$ 2170$ & 22212 & $\$ 2483$ & $\$ 313$ \\
\hline 12213 & $\$ 2576$ & 22213 & $\$ 2191$ & $\$ 385$ \\
\hline 12221 & $\$ 2037$ & 22221 & $\$ 1867 *$ & $\$ 170$ \\
\hline 12222 & $\$ 1902$ & 22222 & $\$ 2804 *$ & $\$ 902$ \\
\hline 12223 & $\$ 1919$ & 22223 & $\$ 2943$ & $\$ 1024$ \\
\hline 12231 & $\$ 2972$ & 22231 & $\$ 1014 *$ & $\$ 1958$ \\
\hline 12232 & $\$ 3333$ & 22232 & $\$ 1062 *$ & $\$ 2271$ \\
\hline 12233 & $\$ 3839$ & 22233 & $\$ 3421$ & $\$ 418$ \\
\hline
\end{tabular}

The grand mean for the total group is $\$ 2999$. Mean Earnings by Sex, Race, and Treatment:

Black Male Participants - $\$ 3431$

White Male Participants - \$3507 
TABLE XI (Continued)

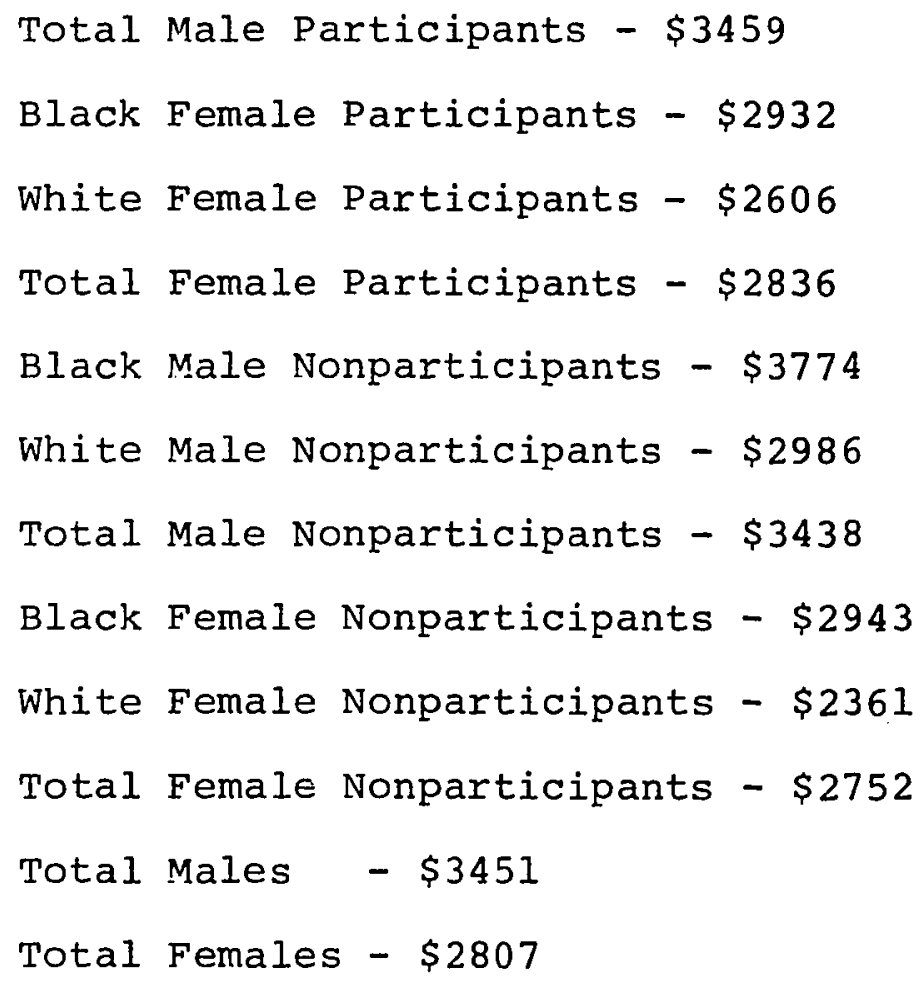


and 12 years of education, (those with 12 years of education earned only $\$ 30$ more than the participant group). All other White male participant groups by age and education earned more than did white male nonparticipants, and often the difference is fairly large. It must be noted that although White male participants earned a total of 76 dollars more than Black male participants, the Black male nonparticipant group earned $\$ 788$ more than the white male nonparticipant group. With combined races male participants earned only 21 dollars more than male nonparticipants. Black male participants ages $0-20$ with 12 years of education or more earned more than did similar white participants and nonparticipants. The incomes of Black males ages 21-25 years with 12 years of education or better exceed the incomes of similar white male participants and nonparticipants.

The mean earnings of Black female nonparticipants was almost equal to the earnings of Black female participants. With the factors age and education included, the earnings of Black female participants ages $0-20$ anā $21-25$ years of age with 10-11 years of education exceed similar nonparticipants by $\$ 353$ and $\$ 245$ respectively. In Other Black female groups with sufficient cell size, nonparticipant incomes exceeded those of participants. Female white participant earnings exceeded the earnings of similar nonparticipants by $\$ 245$. Reliable conclusions concerning the effects of age and educational factors are difficult to 
formulate due to the small cell sizes. It does appear that female white participants with 12 years of education or better and between the ages of $0-20$ and 26-44 earned more than similar nonparticipants. Female white nonparticipants with 12 years of education or more ages 21-25 earned more than similar participants, but the cell sizes limit the reliability of the difference. Black female nonparticipants earned $\$ 582$ more than did white female nonparticipants. Black female participants earned $\$ 326$ more than White female participants. With combined races female participants in the PCEP earned $\$ 84$ more than did females in the control group. With the exceptions of females aged 26-44 at all educational levels, Black female participants earned more than white female participants in similar age and education groups.

Median Earnings 1973

Examination of the median earnings by code group confirms the pattern revealed in the analysis of mean earnings. The Black male participant group did slightly worse in comparison with the Black male nonparticipant group using median earnings. The only Black male participant group to earn more than the nonparticipant group was the group aged 0-20 years with $10-11$ years of education. The Black male participant groups ages $0-20$ and $26-44$ years with 12 years of education which had demonstrated small advantages over 
the control group using mean earnings, earned less than the control group using median earnings. The differences between the amount earned by participating Black males and the control group were greater using median earnings. Among White males the findings were reversed in three groups. White male participants ages 0-20 with 10-11 years of education earned slightly more than the similar control group using median earnings. The white male participants ages 0-20 and 21-25 years with 12 years of education earned slightly less than the control groups. Black female and white females demonstrated similar relationships with their control groups using median and mean earnings. Using median earnings the large difference between male and female earnings remained. White male participants continued to earn slightly more than Black male participants. The Black participant group both male and female continued to earn more than the white male and female control groups. The relationships between participating white groups and nonparticipating Black groups was identical using median earnings, i.e., the same Black control groups earned more than the same White participant groups.

FAMILY HEADS AND WELFARE RECIPIENTS IN THE PCEP

The Olympus study found that the most single important variable in statistically explaining the level of posttraining wage rates was the number of dependents. Wage 
rates rose consistently as dependents increased up to three or four, and then turned down with five or more. ${ }^{111}$ The responsibility to provide income for persons other than yourself may increase motivation to obtain and retain employment. Unfortunately, the number of dependents was not recorded for persons involved in this study. Information was obtained on persons participating in the PCEP who reported themselves as "head of family" upon enrollment in the program. Persons currently receiving welfare payments at the time of enrollment were also noted. This information was not available on the control group. Persons who reported themselves as "Head of Family" and "Welfare Recipient" cannot be matched with their eventual 1973 incomes on an individual basis, but the percentage of each code group in these categories was computed. 
TABLE XII
PCEP PARTICIPANTS REPORTED AS "HEAD OF FAMILY" AND "WELFARE RECIPIENTS" BY PERCENT OF CODE GROUP

\begin{tabular}{|c|c|c|c|}
\hline Code & Group & $\begin{array}{l}\text { Percent Head } \\
\text { of Family }\end{array}$ & $\begin{array}{l}\text { Percent } \\
\text { Welfare Recipients }\end{array}$ \\
\hline
\end{tabular}

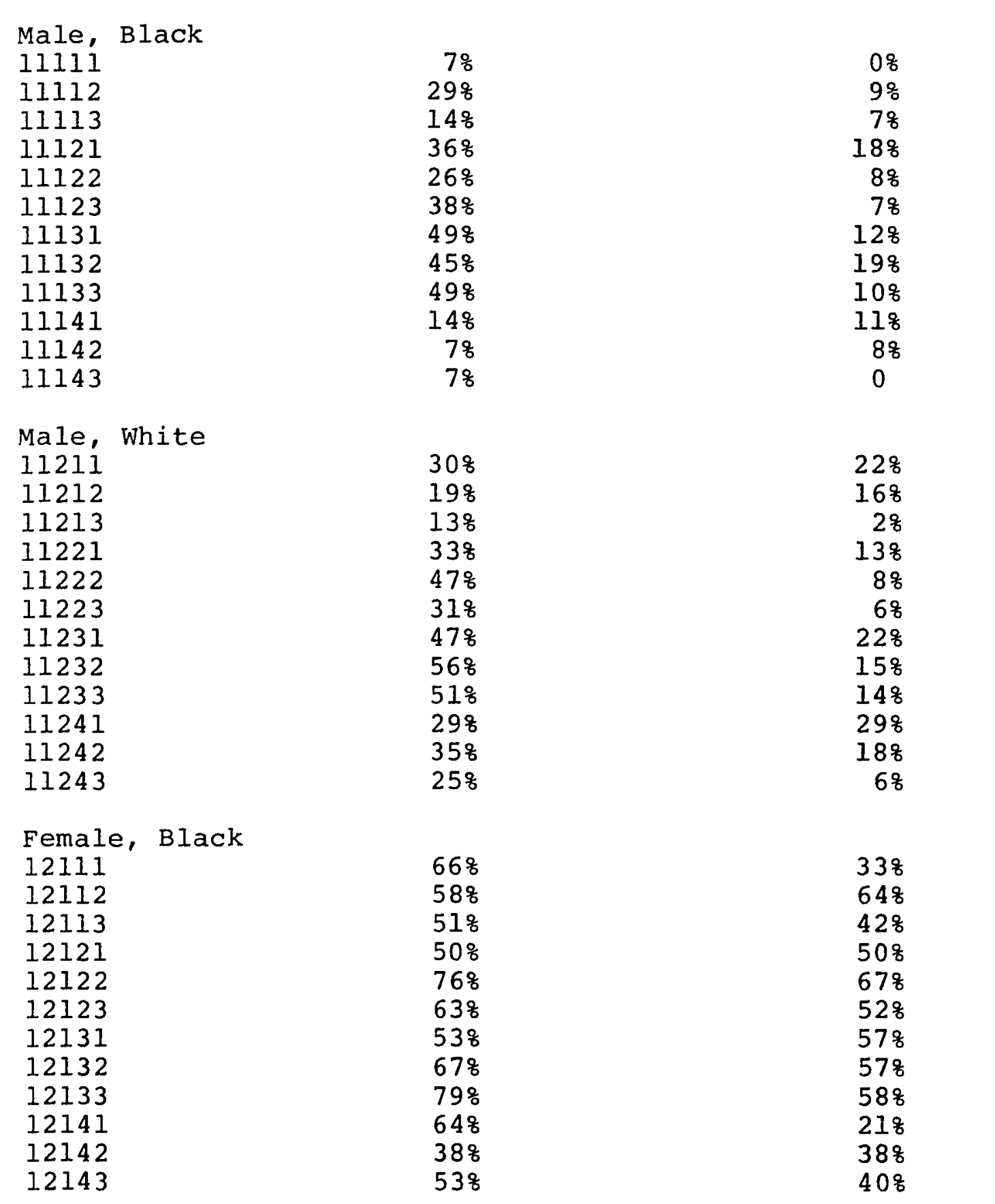


TABLE XII (Continued)

Percent Head of Family

\begin{abstract}
Percent Welfare Recipients
\end{abstract}

$\begin{array}{lrr}\text { Female, White } & & \\ 12211 & 33 \% & 22 \% \\ 12212 & 2 \% & 9 \% \\ 12213 & 19 \% & 11 \% \\ 12221 & 418 & 18 \% \\ 12222 & 36 \% & 18 \% \\ 12223 & 41 \% & 298 \\ 12231 & 548 & 46 \% \\ 12232 & 768 & 71 \% \\ 12233 & 75 \% & 57 \% \\ 12241 & 56 \% & 33 \% \\ 12242 & 60 \% & 20 \% \\ 12243 & 73 \% & 45 \% \\ \text { Total Male, Black } & 36 \% & 10 \% \\ \text { Total Male, White } & 35 \% & 13 \% \\ \text { Total Female, Black } & 65 \% & 54 \% \\ \text { Total Female, White } & 39 \% & 28 \% \\ \text { Total Males } & 36 \% & 11 \% \\ \text { Total Females } & 56 \% & 46 \%\end{array}$


The presence or absence of a positive relationship between Head of Family and income is difficult to assess without further statistical analysis. There is no method to determine the number of dependents in each category. Furthermore, within each sex and race category, with the exception of Female Blacks, the groups with the highest percentages of "Heads of Family" are generally the older participants of prime labor force age. However, persons who are "Heads of Families" may earn higher wages. The White male group aged 21-25 years with 10-11 years of education reported 478 "Head of Family". The mean earnings not including zero earners of this group were $\$ 1068$ greater than the similar group with $1-9$ years of education and 338 "Head of Family"; and $\$ 795$ greater than the similar group with 12 years of education and $31 \%$ "Head of Family". The White female groups with $50 \%$ or higher "Head of Family" had higher incomes than any other white female groups. There is a possibility that family responsibilities do have a positive association with income. Future studies should include the number of dependents as an independent variable.

\section{TRAINING VARIABLES FOR PCEP PARTICIPANTS AND MEAN EARNINGS}

The participants in the Portland Concentrated Employment Program included in this study were enrolled in the program at different times over a four-year period, received 
differing services and training, for varying lengths of time. A second code including these variables on participants only was submitted to the Social Security Administration. Earnings for persons in the second code groups were reported by the SSA in the same manner as earnings under the first code. It is impossible to determine the sex and age of persons included in the second code groups. Due to time and money constraints, only a brief analysis of the findings of the second code group are reported. Earnings were reported on 1680 persons who had participated in the PCEP and who were included in the first code groups. An explanation of the code is given in Table XIII.

The participants in the PCEP involved in this study were enrolled in the program during the period from November 1968 through December 1972. All persons had completed training during this period. The SSA earnings are mean earnings for the calendar year 1973. Consequently, the period intervening between completion of the PCEP and the period in which earnings were reported varies from one to four years. Table XIV presents earnings information by year of completion for participants.

The highest mean earnings are reported for participants who completed the program in the year prior to 1973 and who have the least labor force experience since training. This suggests the possibility that benefits from training may be highest during the year or two following 


\author{
TABLE XIII \\ SECOND CODE: \\ PCEP PARTICIPANTS ONLY
}

Four Independent Variables - I II III IV

I. Year PCEP Completed - 7. 1968 and 1969

8. 1970

9. 1971

0.1972

II. Length of Stay in PCEP - 6. $0-5$ weeks 7. $6-25$ weeks

8. $26-49$ weeks

9. 50 weeks and over

III. Years of Education Completed - 6.1 - 9 years

7. 10 - 11 years

8. 12 years and over

IV. Type of Services:

6. Public Employment - Operation Mainstream, STEP Neighborhood Youth Corps, Work Experience

7. On-the-Job-Training and NABS JOBS

8. Basic Education

9. Orientation only

0 . Institutional/Skills Training - VOC 1, 2, \& 3; CEP VOC, MDTA CEP, MDTA OSES

1. New Careers

2. Hold only and Placement

Example: 0681 - Completed 1972, 0 - 5 weeks length of stay, 1 - 9 years of education, New Careers 
TABLE XIV

\section{MEAN EARNINGS BY YEAR TRAINING} WAS COMPLETED IN PCEP

\begin{tabular}{lcc} 
Year Completed & Frequency & Mean Earnings \\
\hline 1968 and 1969 & 368 & $\$ 2199$ \\
1970 & 307 & $\$ 2001$ \\
1971 & 495 & $\$ 2418$ \\
1972 & 368 & $\$ 2487$
\end{tabular}


the training period or that the training programs offered by the PCEP had improved markedly with experience. However, other important variables appear to vary by the year training was completed and may be responsible for the differing mean earnings by year.

Education, which was an important explanatory variable influencing income under the first code, appears to explain part of the variation between mean earnings by training year. Fifty-seven percent of participants who completed training in the year 1970, the year with the lowest mean earnings, had less than a high school education, as compared to forty-seven percent in 1972, the year with the highest mean earnings. The percentage of participants completing the program each year with a high school education upon entrance to the program appears to be directly related to the mean earnings by year. Education appears to explain a portion of the variation in mean earnings by completion year. Conversely, mean earnings by years of education completed appear to vary by year that PCEP was completed. These variations may be due to varying percentages of males and females or differing ages between those participants finishing the programs in different years. Other variables included in the study which may affect the variation in income are length of stay in the program and type of services received. 
TABLE YV

EDUCATION OF PARTICIPANTS BY YEAR PCEP COMPLETED: BY PERCENT

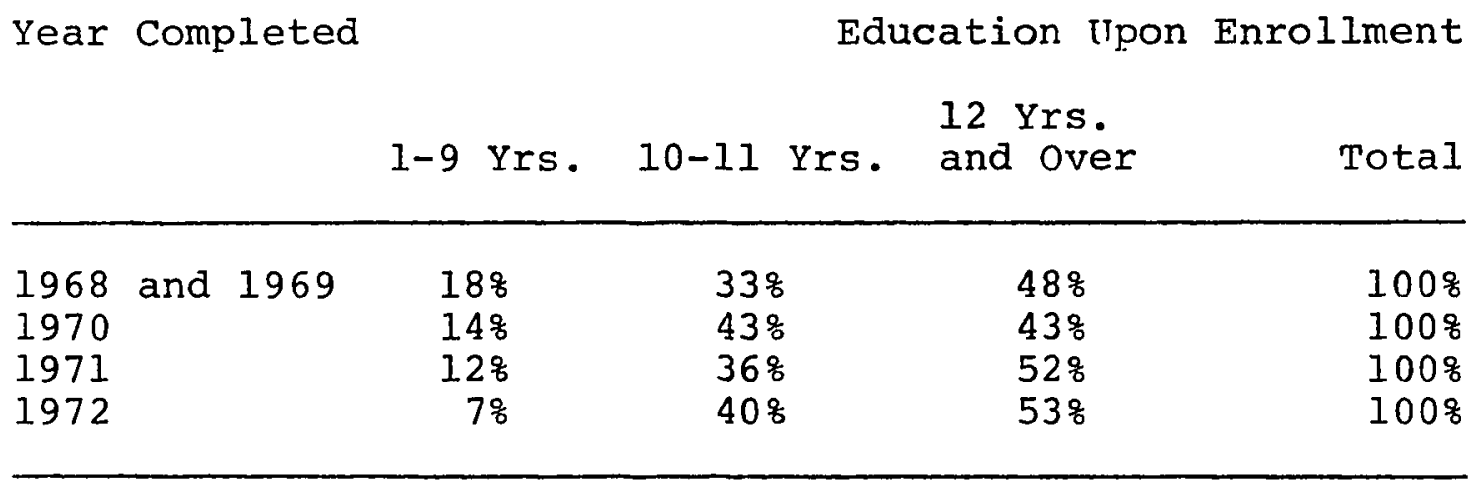

TABLE XVI

MEAN EARNINGS 1973 BY YEARS OF EDUCATION COMPLETED AND YEAR PCEP COMPLETED

Year Completed

Years of Education Completed

\begin{tabular}{|c|c|c|c|}
\hline & $\begin{array}{c}1-9 \text { Yrs } \\
\text { Mean }\end{array}$ & $\begin{array}{c}\text { 10-11 Yrs. } \\
\text { Mean }\end{array}$ & $\begin{array}{c}12 \text { Yrs } \\
\text { and Over } \\
\text { Mean }\end{array}$ \\
\hline $\begin{array}{l}1968 / 1969 \\
1970 \\
1971 \\
1972\end{array}$ & $\begin{array}{l}\$ 1421 \\
\$ 1900 \\
\$ 2023 \\
\$ 1523\end{array}$ & $\begin{array}{l}\$ 1979 \\
\$ 1679 \\
\$ 1953 \\
\$ 2072\end{array}$ & $\begin{array}{l}\$ 2975 \\
\$ 2354 \\
\$ 2725 \\
\$ 2926\end{array}$ \\
\hline
\end{tabular}


Types of Service

Participants enrolled in the PCEP received many different combinations of services and training. The participants involved in the study may have received orientation, basic education, institutional skill training, placement, or any combination of these services. Persons may have been enrolled in publicly funded work experience programs such as the Neighborhood Youth Corps, Operation Mainstream, STEP, or CEP Work Experience. A small percentage of persons were enrolled in private on-the-job training programs, NABS JOBS, and New Careers. In this study participants were included under the category of training in which they spent the longest period of time. All participants except those in the "Hold Only" category participated in orientation. Persons who received basic education and more than four weeks of other training were classified under the latter category.

The New Careers program enrolled primarily minority people of above average education who were to be given access to entry-level white-collar jobs and advanced education for those presumed to have the ability and ambition to progress from there. Eighty percent of the participants in the PCEP enrolled in New Careers had a high school degree or better on entrance. The twenty percent who had 10-11 years of education received basic education prior to their transfer to the New Careers program. 
TABLE XVII

MEAN EARNINGS BY TYPE OF TRAINING: BY PERCENT

\begin{tabular}{lccc} 
Type of Training & $\begin{array}{r}\text { Number of } \\
\text { Persons }\end{array}$ & $\begin{array}{r}\text { of of } \\
\text { Total }\end{array}$ & $\begin{array}{c}\text { Mean Earnings } \\
1973\end{array}$ \\
\hline $\begin{array}{l}\text { Institutional/ } \\
\text { Skills Training }\end{array}$ & 213 & $13 \%$ & $\$ 2127$ \\
New Careers & 103 & 68 & $\$ 3724$ \\
\hline
\end{tabular}

TABLE XVIII

MEAN EARNINGS BY TYPE OF SERVICE :

BY PERCENT

$\begin{array}{lrrr}\text { Hold Only and Placement } & 74 & 48 & \$ 3410 \\ \text { PubIic Employment } & 401 & 24 \% & \$ 2115 \\ \text { OJT and NABS JOBS } & 73 & 48 & \$ 2788 \\ \text { Basic Education } & 252 & 15 \% & \$ 1611 \\ \text { Orientation } & 564 & 348 & \$ 2287 \\ & - & -100 \% & \$ 2284\end{array}$


Persons included in the "Hold Only and Placement" category were considered by the PCEP to be "job ready" upon entrance. Placement was the only PCEP service obtained by these participants. Eighty percent of the persons in this category had a high school education.

The NABS JOBS program and the on-the-Job-Training programs involved training provided by private employers with continued employment after completion of a satisfactory training period. Sixty-six percent of the persons in these programs had a high school degree on entry. Forty-four percent had 10-11 years of education.

During the first two years of operation, the PCEP appears to have relied more heavily on orientation, basic education, and the public employment programs. Participants completing during 1971 and 1972 are more evenly distributed among the different services.

Length of stay in the PCEP

The period in which a participant was enrolied in the PCEP varied from one week to over one year. Length of stay in the program does not appear to vary directly with income, or education. Length or time in the program did not dictate the training content.

In every year participants who spent 6-25 weeks in the program had the lowest mean earnings. The highest total mean earnings were received by persons with $0-5$ weeks in the 
TABLE XIX

TYPE OF TRAINING BY YEAR COMPLETED:

BY PERCENT

Type of Training

Year Completed

$1968 / 69$

1970

1971

1972

Institutional/Skills

Training

98

138

118

$20 \%$

New Careers

$0 \%$

$7 \%$

58

158

Hold Only

0 웅

$5 \%$

58

98

Public Employment

$15 \%$

238

398

178

OJT/NABS JOBS

08

0 요

88

98

Basic Education

$12 \%$

$19 \%$

168

$15 \%$

Orientation

648

$33 \%$

169

158

$100 \%$

$100 \%$

100

1008 
TABLE XX

LENGTH OF STAY AND MEAN EARNINGS 1973 BY YEAR COMPLETED

\begin{tabular}{|c|c|c|c|c|c|c|c|c|c|}
\hline Year & Completed & & & $6-$ & & & 50 Weeks & $\begin{array}{r}\text { Length } 0 \\
50 \\
\text { and }\end{array}$ & $\begin{array}{l}\text { stay } \\
\text { eeks } \\
\text { Over }\end{array}$ \\
\hline & & $\begin{array}{l}\text { Fre- } \\
\text { quency }\end{array}$ & $\begin{array}{l}\text { Mean } \\
\text { Earning }\end{array}$ & $\begin{array}{l}\text { Fre- } \\
\text { quency }\end{array}$ & $\begin{array}{l}\text { Mean } \\
\text { Earning }\end{array}$ & $\begin{array}{l}\text { Fre- } \\
\text { quency }\end{array}$ & $\begin{array}{l}\text { Mean } \\
\text { Earning }\end{array}$ & $\begin{array}{l}\text { Fre- } \\
\text { quency }\end{array}$ & $\begin{array}{l}\text { Mean } \\
\text { Earning }\end{array}$ \\
\hline 1968 & and 1969 & 288 & $\$ 2306$ & 193 & $\$ 1993$ & 29 & $\$ 2509$ & 0 & 0 \\
\hline 1970 & & 123 & $\$ 2415$ & 106 & $\$ 1612$ & 42 & $\$ 1247$ & 36 & $\$ 2609$ \\
\hline 1971 & & 121 & $\$ 2473$ & 205 & $\$ 1909$ & 117 & $\$ 2490$ & 52 & $\$ 3574$ \\
\hline 1972 & & 90 & $\$ 2914$ & 155 & $\$ 1917$ & 77 & $\$ 2283$ & 46 & $\$ 3899$ \\
\hline Total & & 622 & $\$ 2449$ & 659 & $\$ 1888$ & 265 & $\$ 2235$ & 134 & $\$ 3426$ \\
\hline
\end{tabular}


TABLE XXI

PERCENT OF PARTICIPANTS IN "LENGTH OF STAY" CATEGORY BY YEAR COMPLETED

\begin{tabular}{|c|c|c|c|c|c|}
\hline Year Completed & 0 - 5 Weeks & $6-25$ Weeks & 25 - 50 Weeks & $\begin{array}{l}50 \text { Weeks } \\
\text { and Over }\end{array}$ & Total \\
\hline 1968 and 1969 & 56 & 388 & 68 & 08 & $100 \%$ \\
\hline 1970 & 408 & $35 \%$ & $14 \%$ & 128 & $100 \%$ \\
\hline 1971 & 258 & 41 & $24 \%$ & $10 \frac{8}{8}$ & $100 \%$ \\
\hline 1972 & 248 & $42 \%$ & 218 & $13 \%$ & $100 \%$ \\
\hline
\end{tabular}


program and 50 weeks and over. Those with zero to five weeks were enrolled in "Orientation" and the "Hold only and Placement", with the exception of eight percent who were enrolled in public employment programs. Forty-seven percent of those with 0-5 weeks in the program had less than a high school education. Of those persons in the 50 week and over period, sixty percent were enrolled in New Careers, 17 percent were enrolled in institutional skills training, 15 percent were enrolled in public employment programs, and the remaining eight percent were evenly divided between OJT/NABS JOBS and Basic Education. Thirty-four percent had less than a high school education. There does appear to be a positive relationship between length of stay in the program and Basic Education. Two percent of those enrolled in Basic Education had a high school degree. Of the ninety-eight percent with less than a high school education, those with 26 to 50 weeks, anci 50 weeks and over received mean incomes of approximately $\$ 1000$ greater than those enrolled in Basic Education for $0-5$ weeks and 6-25 weeks. This Eigure may reflect differing degrees of motivation during training the less motivated having shorter training periods - which carried over into employment opportunities.

\section{Conclusions}

Mean earnings for 1973 vary by the year in which the participant completed the program. Percentage of participants with a high school degree appears to vary directly 
with increase in mean earnings by year the PCEP was completed. Differences in years of education completed among participants completing the program each year appears to have a direct influence on mean earnings. Conversely, mean earnings by years of education completed differ according to the year the PCEP was completed. These differences may be affected by the variables sex, age, type of training, length of stay in the program, or other factors not included in the study. Participants receiving the highest mean earnings by type of services received were enrolled in the New Careers program or received only placement services from the PCEP. Previous training, education, and work experience contributed to the high earnings of the "Hold only" group, but the placement services available at the PCEP facilitated their reentry into the labor force. Eighty percent of those enrolled in New Careers had a high school diploma upon entry to the program. Persons enrolled in the program were presumably selected for their abilities and ambition which may have contributed to their eventual higher earnings. Although their earnings were high in relation to other PCEP participants, they are low compared to the average incomes of the U.S. labor force with similar levels of education. NABS JOBS and On-the-Job-Training programs, which included only four percent of the PCEP participants, resulted in the third highest mean income. Seventy-one percent of the participants were enrolled in three different types of services 
and received mean incomes between $\$ 2100$ and $\$ 2300$. Of those enrolled in institutional skills training, 41 percent had less than a high school education and received a mean earning of $\$ 2007$. Fifty-nine percent had a high school degree and received a mean income of $\$ 2210$. Of those involved in only orientation, 34 percent had 1-11 years of education and received a mean income of $\$ 2738$. Those with a high school degree enrolled in Orientation received a mean income of \$2053. Of those involved in Public Employment programs, 458 had less than a high school degree. There was little difference in mean earnings between those with a high school degree and those without one. Thus, there appears to be little direct relationship between type of training for the majority of participants and education and their influence on income. Differences in sex, age, motivation or other variables not included in the second code may explain the differences in mean income by training. Persons enrolled in Basic Education who received no other substantial training were the most disadvantaged in terms of education levels of the participants and received the lowest mean income. Mean incomes for persons enrolled in the program from 6-25 weeks were the lowest of any category by length of stay in the program. Although 47 percent of those with $0-5$ weeks in the program had less than a high school education, their total mean earnings were higher than the total mean earnings of those with similar education. Quick placement in a job 
may have resulted in higher eventual earnings than training programs offered by the PCEP. Training periods of over 50 weeks appear to result in higher earnings, although 66 percent of those enrolled for this period had 12 years of education and over and might be expected to earn higher incomes. The longer training period may provide specific, marketable job skills which the intermediate length programs do not provide. Persons remaining in the program for a long length of time may also have greater motivation and persistence than those in the program for shorter periods of time.

\section{STMMAARY}

Analysis of variance on the 1973 mean earnings of participant groups in the PCEP and control groups of persons who were admitted to the PCEP but for unknown reasons failed to enroll in the program resulted in the following findings:

of the five independent variables - Treatment (Participation or nonparticipation in the PCEP), sex, race, age, and education - there were significant interactions between Treatment, Race, and Age; Treatment and Race; and Sex and Age.

The interaction between treatment, race and age appears to result from the differing performances of the Blacks and Whites by age and treatment. Black participants and the White control group earned their highest incomes in 
the age group of 21-25 years. White participants and the Black control group had generally rising incomes as age increased up to 45 years. The PCEP was not as effective in serving mature Blacks as was predicted. All groups ages 45 years and over earned low incomes relative to other groups in the study.

The interaction between treatment and race is apparently the result of the differing performances of the Black and White control groups. The Black control group in most cases earned more than the Black participants, White participants and the White control group. The Black participants earned slightly more than the White participants. The White participant group appears to have benefitted more from participation in the PCEP in comparison with their control group, than did Black participants. Whites failed to earn significantly more than Blacks. Enrollment in the PCEP in most oases did not raise the incomes of participants significantly higher than the incomes of the control group. Sex and age demonstrated a significant interaction which is primarily due to the poor performance of males ages 45 years and over. In all other age groups males had significantly higher earnings than did females. Male earnings were highest between the ages of 21-25 years. Female earnings reached their peak between the ages of 26-44 years. Sex appears to be a stronger variable than age. The findings confirm the hypotheses that males earn more than 
females, and that persons 45 years and over have less labor market success than younger persons. The hypothesis that income increases with age was confirmed, although males demonstrated a nonsignificant decrease in income between the age groups 21-25 years and 26-44 years.

As hypothesized, education is an important variable affecting incomes. The groups with a high school degree and under 45 years of age earned significantly more than those without a high school degree. The education group benefitting most from participation in the PCEP included persons with 1-9 years of education. Persons with 10-11 years of education, particularly Blacks, benefitted least from participation in the PCEP. This finding implies that the most severely educationally disadvantaged persons receive sufficient education or training to enable them to obtain better employment than similar persons who did not participate in the PCEP. But, the PCEP was markedly unsuccessful in raising the educational capabilities of persons with 10ll years of education, particularly Blacks, sufficiently to narrow the earnings difference attributable to possession of a high school degree.

Persons who are heads of families may have better labor force potential than persons who do not have family responsibilities. 
The greatest benefits from participation in the PCEP are secured by persons enrolled in the program from zero to five weeks and over fifty weeks. Persons enrolled from six to 25 weeks received the lowest total mean earnings. The majority of participants were enrolled in three components of the program - orientation, public employment, and institutional skills training. The mean earnings of persons enrolled in these programs were similar. Quick placement may have been more beneficial than longer training for many persons in these components.

Persons enrolled primarily in basic education were the most educationally disadvantaged. This group earned the lowest mean incomes by type of service received. Longer enrollment periods in basic education are apparently more beneficial than shorter periods. 
78. Congress and the agencies administering manpower programs placed a high priority on education and training and a low priority on correcting the acknowledged problem of labor market discrimination which may prevent the disadvantaged clientele for reasons of race, sex, age, education, etc. from obtaining jobs which bestow above poverty level incomes, employment stability, and other benefits to the employee. As Peter B. Doeringer and Michael J. Piore point out in Internal Labor Markets and Manpower Analysis, employment discrimination is a complex process.

"The rules which result in employment discrimination are not designed to effectuate discrimination alone, but are part of the total fabric of labor pricing and allocation. The rules represent the desire of the incumbent labor force to protect employment benefits such as job security and advancement opportunities, and the employers interest in minimizing the fixed costs of recruitment, hiring and training. For example, where two racial populations differ significantly in terms of the proportion of persons possessing certain desired characteristics, the most efficient hiring policy may be simply to reject all members of one racial population. Screening by race is less expensive than developing a new process to select qualified workers from the second race. The existing labor force for reasons of selfinterest would be likely to resist attempts to a policy intending to give priority in hiring and promoting members of the other race since this would threaten their own positions. Hence, it is not generally possible to change the distrivution of jobs between the races without imposing costs on the incumbent employees and the employer. Discrimination is most often effected by entry, allocation, and wage instruments of labor market adjustment process. To eliminate discrimination with the least possible costs the intricacies of the rules resulting in discrimination and their effects should be thoroughly studied." (Paraphrased by the author). 
FOOTNOTES - CHAPTER V (Continued)

79. For examples of national impact studies see:

Olympus Research Corporation, The Total Impact of Manpower Programs: A Four City Case Study, Washington, D.C.: U.S. Department of Labor, August 1, 1971; Gerald G. Somers, ed., Retraining the Unemployed (Madison: University of Wisconsin Press, 1968); Garth I. Mangum, MDTA: Foundations of Federal Manpower Policy (BalEimore: John Hopkins Press, 1968).

80. 1975 Manpower Report of the President (Washington, D. C.: U.S. Government Printing Office, 1975), p. 317 .

81. Garth L. Mangum and David Snedeker, Manpower Planning for Local Labor Markets (Salt Lake City: Olympus Publishing Co., 1974), p. 281.

82. Peter H. Rossi and Walter Williams, editors, Evaluating Social Problems (New York: Seminar Press, 1972).

83. Tom R. Houston, Jr., "The Behavioral Sciences ImpactEffectiveness Model", editors, Peter H. Rossi and Walter Williams, Evaluating Social Programs (New York: Seminar Press, 1972), p. 51.

84. John W. Scanlon, et al. An Evaluation System to Support Planning, Allocation and Control in a Decentralized Comprehensive Manpower Program (Washington, D.C.: The Urban Institute, 1971), p. 10 .

85. Garth L. Mangum and R. Thayne Robson, "Measures of the Impact on the Community":, ed. Michael E. Borus, Evaluating the Impact of Manpower Programs (Lexington: D.C. Heath and Co., 1972), p. 139 .

86. Garth L. Mangum, Manpower Planning for Local Labor Markets (Salt Lake City: Olympus Publishing Co., 1975), p. 208.

87. The exclusion of individuals whose files were incomplete or unavailable introduces a possible bias into the study. In the author's opinion the bias is negligible. 
FOOTNOTES - CHAPTER V (Continued)

88. No identifying mechanism was included to separate dropouts from completers.

89. Einar Hardin, "On the Choice of Control Groups", editors, Peter H. Rossi and Walter Williams, Evaluating Social Programs (New York: Seminar Press, 1972), p. 41 .

90. Michael E. Borus and William R. Tash, Measuring the Impact of Manpower Programs: A Primer /Ann Arhor: University of Michigan - Wayne State University; Institute of Labor and Industrial Relations, 1970), p. 19 .

91. Ibid., p. 18 .

92. Einar Hardin, p. 51 .

93. Persons in the control group are not identical to those in the treatment group. Although the demographic characteristics of the two groups are similar and both groups are eligible for the program, there exist unknown differences between the two groups. The control group introduces a possible bias of unknown magnitude into the study.

94. William R. Tash, "Sources of Fconomic Data in Manpower Evaluation Studies: Comment", editors, Peter Rossi and walter Williams, Evaluating Social Programs (New York: Seminar Press, 1972), p. 211.

95. Ibid.

96. The data purchased from the SSA does appear to include total earnings. Incomes over $\$ 10,800$ were reported in the data.

97. Less than 2.1 percent of the individuals in this study earned more than $\$ 10,500$ in 1973 .

98. Robert N. Heller, "The Uses of Social Security Administration Data", ed., Michael E. Borus, Evaluating the Impact of Manpower Programs (Lexington: D.C. Heath and Co., 1972), p. 200 .

99. Eleven cells out of 138 were deleted by the SSA or the author because they contained less than five individuals. 
FOOTNOTES - CHAPTER V (Continued)

100. All local units of government and non-profit agencies in the Portland area who were known to employ manpower program participants are covered by the SSA.

101. Garth L. Mangum, MDTA, pp. 126-131.

102. Ronald Oaxaca, Male-Female Wage Differentials in Urban Labor Markets (Springfield: National Technical Information Service (PB 199974), 1971), p. 168 .

103. Peter B. Doeringer and Michael J. Piore, Internal Labor Markets and Manpower Analysis (Lexington: D.C. Heath and Co., 1971), p. 164.

104. Ibid., p. 164.

105. August Bolino, Manpower and the City (Cambridge: Schenkman Publishing Co., 1969), p. 34.

106. E.F. Lindquist, Design and Analysis of Experiments in Psychology and Education (Boston: Houghton Mifflin Co., 1953).

107. William L. Hays and Robert L. Winkler, Statistics: Probability, Inference and Decision, Volume II (New York: Holt Rinehart and Winston, Inc., 1970), p. 169-171.

108. Olympus Research Corporation, The Total Impact of Manpower Programs, p. 30.

109. Ibid., p. 30.

110. Ibid., p. 5.

11l. Ibid., p. 39. 
CHAPTER VI

SUMMARY AND CONCLUSIONS

Manpower programs for the disadvantaged have been operated in the U.S. for approximately fifteen years. The programs - introduced under the authority of the Manpower Development and Training Act, the Economic opportunity Act, the 1967 amendments to the Social security Act and the Comprehensive Training and Employment Act - were all concerned with the employment and earnings of certain groups. The crucial impact measure, therefore, is that on the lives of the enrollees. Has their participation in a manpower program led to higher incomes and stable employment? Did the benefits of the program justify the costs to both the individual participants and the society?

The evaluation of the impact of the PCEP on the incomes of participants does not result in brief, conclusive answers to the major questions. In reviewing the findings of this research, the constraints imposed by the research design and the data on which the findings are based must be kept in mind. The primary limitations of the study are reviewed in the following paragraphs.

The control group was selected from applicants to the PCEP who did not participate in the PCEP. The reasons for 
the nonparticipation of the control group are unknown. It is possible that the individuals in the control group were characterized by superior or inferior labor market potential when compared to the participants. The participant and the control groups may not in fact be comparable. If this is the case, and there is no method to determine whether the two groups are completely comparable, then the conclusions based upon comparisons between the participant and the control groups are unfounded. However, based upon analysis of the results, the author endorses the assumption that the groups are comparable. The original hypothesis assumed that, due to labor market discrimination, whites in the study would earn more than Blacks. This hypothesis was not confirmed by the research findings. Instead, both the Black participant and control groups earned more in 1973 than did the White participant and control groups. The difference in earnings indicates that the labor force potential of Black applicants to the PCEP was superior to that of whites applying to the program. The PCEP served a high unemployment, racially mixed geographic area with a high incidence of poverty among the population. Whites living within this geographic area and applying to the PCEP are apparently characterized by a lower ability preparedness than Black applicants. This hypothesized initial difference in the population by race is consistent with the income findings. 
Mean incomes differed between races but were fairly consistent within each racial group. Given the size of the groups, the similarities in demographic characteristics, the similarities in earnings distributions, the corresponding percentages of zero earners, and comparable mean earnings the author concludes that the Black control group is comparable to the Black participant group.

The smaller number of Whites involved in the study and a higher percentages of zero earners among nonparticipant White females, leaves in question the possibility that the White control group, particularly the female control group, may not be comparable to the White participant group. Their failure to participate in the PCEP may be indicative of a weak attachment to the labor force. If this is true, then the study is biased in favor of the white participant group. The conclusions reached in this chapter are based on the assumption of comparability between the participant and the control groups.

For reasons of confidentiality, the social security Administration's earnings data is reported only on groups of five individuals or more. No information on employment is provided. Small groups reduce the reliability of the incomes reported. Mean earnings reported by group may obscure information which would have emerged from analysis of individual incomes. The reporting of group earning severely limited the ability of the analyst to manipulate the data. 
The utilization of aggregate data from secondary sources imposes constraints on the ability of the author to formulate reliable conclusions. Due to limitations on time and funds, the research did not utilize primary sources which may have provided a valuable check on the incomes reported by the SSA as well as more in-depth information concerning the reasons for the apparent success or failure of the program to effect expected changes.

These conceivable shortcomings of the research should be considered when reviewing the findings in the following sections.

THE IMPACT OF THE PORTLAND CONCENTRATED

EMPLOYMENT PROGRAM ON THE INCOMES OF PARTICIPANTS

Over seventy percent of the persons included in this study in both the participant and the control groups earned incomes below the official poverty level of $\$ 4,540$ in 1973 for a nonfarm family of four. Although their incomes were generally higher than their self-reported pre-enrollment incomes, the participants continued to earn considerably less than the average member of the civilian labor force. Participation in a manpower program did not raise the mean earnings of participant groups above the poverty level. The group means for the eight sex/race groups are as follows: 
$\underline{\text { Participants }}$

Black Male - $\$ 2,618$
White Male - $\$ 2,539$
Black Female - $\$ 2,129$
White Female - $\$ 1,738$

Nonparticipants

Black Male - $\$ 2,796$

White Male - $\$ 2,287$

Black Female - $\$ 2,044$

White Female - $\$ 1,331$

Although there are individual exceptions, the mean earnings of the participant and the control groups remain below the poverty level.

The 1970 mean income in Portland, Oregon for all families was $\$ 11,803$. Of persons in the experienced civilian labor force, the median earnings for males and females 16 years and over were respectively $\$ 8,257$ and $\$ 3,796$. The mean income for all Black families was $\$ 8,142$. The median earnings for Black males and females in the experienced civilian labor force were respectively $\$ 5,806$ and $\$ 3,427$. Thus, although the earnings of whites in this study are proportionately lower than those of Blacks to the general population, the earnings of both groups continue to be substantially below that of the experienced workers in the labor force in the Portland metropolitan area.

\section{Benefits and Costs of Participation}

A difference of means test was used to identify which groups gained significant benefits from participation in the PCEP or from presumed labor market experience in the absence of participation. The groups which experienced significant benefit are identified by an asterisk. Other groups in 
which the difference in mean earnings approached significance are unmarked. The eight participant groups which earned more than the similar nonparticipant group and are considered to have benefitted from participation in the PCEP are:

* White males ages $0-20$ years with $1-9$ years of education

* Black females ages 26-44 years with over 12 years of education

* White females ages 26-44 years with 10-11 years of education

Black males ages $21-25$ years with 1-9 years of education

Black females ages 21-25 years with 1-9 years of education

White males ages $26-44$ years with $10-11$ years of education

White females ages 26-44 years with $1-9$ years of education

White females ages 26-44 years with 12 years of education

Considering income alone, approximately thirteen percent of the persons participating in the PCEP gained significant benefits from their enrollment in the program.

In three cases the control group earned more than the participant group:

* Black male ages 26-44 years with 10-11 years of education

* Black female ages 26-44 years with 1-9 years of education

White male ages $0-20$ years with $10-11$ years of education

These findings indicate that of the participant population, six percent may have benefitted more from continued labor market participation than they did from enrollment in the 
PCEP. Participation in the PCEP may have cost these groups in time and income foregone during and after their participation.

The impact of the PCEP was measured against a single criterion - income. Nonmonetary benefits experienced by participants were not considered in this study. The performance of the PCEP in affecting income appears to be disappointing. Why did the PCEP fail to have a significant effect on the earnings of so many of its participants? Although mean earnings differences were not significant by small groups, there did appear to be certain categories of participants which benefitted more from participation and others in which participation in the PCEP failed to have the expected effects on income. These categories are examined in the following sections.

\section{Persons 45 Years and older}

Regardless of race, sex, age or education the population age 45 years and over applying to the PCEP apparently is characterized by a poor potential for employment. The higher percentage of zero earners in all groups over 45 years of age indicates that a large portion of this group either failed to seek or were unable to obtain employment. Two possible factors may contribute to the low earnings of these groups: (1) the population 45 years and over applying and/Or entering the PCEP was characterized by individuals 
lacking motivation towards employment or evidencing severe problems, such as poor health, which necessitated their withdrawal from the labor market; or (2) the lack of marketable skills combined with age presented insurmountable obstacles to employment for disadvantaged persons. Both factors are likely to have affected the earnings of this group.

Unless more exhaustive selection procedures can eliminate the applicants in this group with poor motivation, health, etc., or new jobs are developed which are suitable to the older disadvantaged worker, this group does not appear to be a good investment for limited manpower dollars. The group aged 45 years and over are not included in the following analysis.

$\underline{\text { Sex }}$

Sex had a significant effect on income. As hypothesized in the original research design, males of both races earned significantly more than females of both races. This finding was apparently influenced by several factors: Labor market aiscrimination result.s in women entering lower paid employment regardless of education. (2) Institutionalized discrimination within the PCEP channeled women participants into traditional female occupations, such as clerical work, which are generally lower income jobs. Female participants themselves often did not consider 
traditionally male occupations when setting their employment goals. (4) White females in the younger age groups had higher percentages of zero earners than did other sex and race groups. This figure, in all probability, is a result of younger white females not seeking employment in 1973. The smaller percentages of White female heads of families may indicate that these groups contained many second earners who voluntarily withdrew from the labor market to assume family responsibilities. Female Black groups, reporting a higher number of heads of families, had approximately the same percentages of zero earners as male groups.

Although females received consistently lower earnings than did males, participation in the PCEP appears to have had a more beneficial effect on their earnings than did participation for males, particularly Black males. This finding suggests that females, prior to training, may lack skills or access to employment opportunities, even poorly paid employment. The PCEP services apparently decreased the barriers to employment encountered by female participants. The equivalent number of zero earners between male and female groups with high percentages of family heads, suggests that regardless of the differential in wages, women, who are heads of families, utilize their training and continue to participate in the labor market. Training in occupations with higher income potential might further reduce the number of women withdrawing from the labor force. 
To improve the effectiveness of manpower programs for females and to attain the maximum benefit for training dollars expended, program operators should consider using the number of dependents, or a similar indicator of the strength of labor force attachment, as a screening device for admission into a manpower program. Scarce manpower dollars are most effectively utilized in training persons who will apply their training in employment situations. Persons who are initially rejected by the program could reapply when they are seriously interested in pursuing employment opportunities. Attention should also be paid to the type of training and placements which are provided to female participants. Efforts should be made to eliminate discrimination within the program and to reduce discriminatory practices in the labor market. The program operators should examine their counseling services and eliminate guidance practices which channel males and females into different occupations on the basis of sex. Participants who set narrow, traditionally defined goals for employment should be encouraged to consider other alternatives. Training and placement services should also eliminate discriminatory practices. Training for both sexes should be of sufficient quality to be acceptable to an employer. The program job developers may find it necessary to attempt to influence employers to accept qualified females for nontraditional jobs, just as they must attempt to provide the same 
service for qualified minority applicants for traditionally White jobs. But, at least in initial placements, the manpower program should attempt to screen out persons with a weak attachment to the labor force and to place persons who will be satisfactory workers. Otherwise, employers may be disillusioned with their initial experience and discontinue the contact with the manpower program. In brief, the manpower program operators should attempt to provide services for females with a strong labor force attachment, and to place females in jobs which provide above-poverty income, employment stability and income security.

\section{$\underline{\text { Education }}$}

Education had a significant effect on income. Fxcept for white male participants, all groups with a high school education upon application to the program earned significantly more than groups with less than a high school degree. Although participants with 1-9 years of education earned significantly more than nonparticipants with similar education, they earned significantly less than any group with a high school degree. The lack of significant interaction between treatment and education and the similar slope of the income curves for the participant and nonparticipant groups by education indicates that the educational services provided by the PCEP, particularly for those persons with 10-11 years of education, failed to have the intended effect on 
the income levels of participants. The goal of Graduate Equivalency Degree training and other educational services was to overcome employment barriers by providing dropouts with equivalent educational training. The large difference in earnings between the dropouts and the high school graduates suggests that the PCEP was unable to eliminate the employment obstacle imposed by failure to complete a normal high school education. There are several possible explanations for the wage differentials attributable to a high school degree: (1) The PCEP educational training services may not be equivalent to training received in the average high school. (2) PCEP educational services may not be continued for a long enough period to have an effect on income. (3) Employers may continue to rely on a high school degree, received through the normal educational process, as a screening device for higher income employment; or (4) Persons who dropped out of high school may lack characteristics possessed by high school graduates which lead to more satisfactory job performance and superior employment stability. The latter explanation would prove the least amenable to correction by the manpower program. The first three explanations imply that the wage differential may be eliminated by upgrading the quality of educational services offered by the manpower program, placing increased emphasis on longer training, and/or influencing employers to accept 
qualified dropouts for jobs requiring a high school degree on the assumption that educational training has raised the participants to the level of high school graduates. Modification of educational services may be worthwhile. The earnings differentials indicate that there is a significant payoff in future earnings for high school graduates.

Manpower programs should continue to admit and train persons with $1-9$ years of education. This educational group received the most significant benefit from participation. Functional literacy levels were evidently raised sufficiently to affect the eventual earnings of this educational group. Persons with a high school degree are also beneficiaries of the PCEP. Placement services and such programs as New Careers and NABS-JOBS appear to be the most useful services provided for high school graduates.

Black males with a high school degree did better in comparison with the control group than Black males with lower levels of education. A high school degree had more effect on the earnings levels of Blacks than it did on Whites. This finding suggests that at least part of the earnings differential may be due to racial discrimination. Employers may use a high school degree requirement as an excuse for not employing Blacks, while relaxing the requirement for whites. If the income differential is a function of racial discrimination, then manpower programs 
must deal with the issue of racial discrimination as well as educational discrimination when attempting to influence employers to hire high school dropouts.

Race

Race had a significant effect on the income of persons in the study, but not the effect hypothesized in the research design. Blacks in both the participant and the control groups and of both sexes earned more than whites. There was no significant difference between the white participant group and the white control group. It is possible that this difference in White earnings is due to the poor performance of the control group which may not be comparable to the participant group.

Blacks who benefitted most from their participation in the PCEP were between the ages of 21-25 years. Black females benefitted more from participation than did Black males. Black males with a high school degree benefitted more from the PCEP than did Black male high school dropouts. Blacks benefitted less from participation in the PCEP than did Whites. Black males received the lowest incomes in comparison with their control group. For example, although Black males in the control group with 10-11 years of education received mean incomes several hundred dollars higher than similar nonparticipants with $1-9$ years of education, the Black male participants in these educational groups 
earned similar incomes. The finding that Black males in many cases earned less than their control groups suggests that the PCEP was ineffective in reducing the barriers to employment experienced by this group. The PCEP may have eliminated the expected earnings differential between races by placing persons in jobs where racial discrimination is minimal due to low wages or unsatisfactory working conditions. At best the PCEP failed to place many Black participants in jobs whose incomes were as high as those achieved by the control groups.

Whites apparently benefit more from participation in the PCEP than do Blacks, particularly when comparing the success of high school dropouts. Whites who benefitted most from the PCEP were between the ages of 26-44 years. Although Whites benefit more from the PCEP than do Blacks, their mean income levels when compared to the average white labor force are proportionately less than that of the Black participants to the Black labor force. This suggests that although whites benefit from the manpower program, the PCEP was either dealing with a White population of substantially lower potential than the normal population, or the jobs for which the PCEP trained and had access were of a much lower quality than many alternative occupations pursued by the average White labor force participant. 
RECOMMENDED MODIFICATIONS TO IMPROVE THE EFFECTIVENESS OF MANPOWER PROGRAMS

Although impact evaluations which do not include program monitoring provide information on what happened, they furnish little knowledge about why the outcome occurred. The findings of this study indicate that the benefits to participants in the PCEP were not as substantial as expected. No definitive answers concerning the reasons for the failure of the program to effect the expected changes can be formulated from the existing data. Nevertheless, the findings indicate that serious modifications in manpower program operations may be necessary if participants are to gain substantial benefits.

The most serious implication to emerge from this research is that the PCEP failed to train and place participants in jobs which provided above-poverty level incomes. The income findings suggest that generally the PCEP trained and placed persons in jobs which offered no greater employment stability or higher incomes than jobs which the participants may have attained without participation in a manpower program. Unfortunately, it appears that the pressures to move.clients through the system and to keep average enrollee costs down by quick training and placements, resulted in few long term benefits for the participants. The goal of manpower programs including the PCEP is to obtain not just an immediate job but above-poverty level 
income, employment stability and income security - a satisfying working career. To provide target groups with jobs already available to them or to perpetuate their poverty in lowly paid dead-end jobs is no gain. Without adequate job development and placement services, the attempt to serve as many persons as possible with scarce public manpower funds results in few benefits to participants.

Institutional Barriers to Employment

A manpower program offering skills training, basic education and other services is ineffective if it fails to develop job opportunities for participants which are better than those available to the potential client without the manpower program. If job restructuring, anti-discrimination enforcement, subsidized employment or training and other functions are necessary to provide access to satisfying employment for the disadvantaged, then these functions should receive high priority in manpower funding decisions. Ignoring the importance of these functions and placing an emphasis on the quantity but not the quality of placements is of little ultimate benefit to the participants or the society.

The findings of this research suggest that manpower programs which focus on effecting only individual change may not be sufficient to cause changes in the eventual incomes of the disadvantaged. Programs such as the PCEP which 
expend most of their effort on changing the participant by increasing his job skills, education, motivation, etc. may not be sufficient to affect incomes. Perhaps a higher priority needs to be assigned to functions intended to reduce the institutional obstacles to employment such as racial or educational discrimination. Although services such as basic education and skills training will continue to be necessary if the disadvantaged are to obtain satisfying employment, the existence of institutional obstacles apparently need to be recognized and given a high priority if the so-called "primary labor market" is to be opened to the disadvantaged participants of manpower programs.

The Director of the PCEP and the administrators of the CETA I programs for the City of Portland and the WashingtonMultnomah Consortium, indicated that intense examination of the local labor market and its operation, job development, job restructuring, anti-discrimination enforcement and superior job placements received a low priority in their programs. Persons interviewed recognized the importance and need for these services, but due to time and funding limitations, considered it impossible to devote adequate attention to them. The demands imposed by operating programs along established lines, meeting imposed quotas and coping with emerging crises leave little time for other considerations. 
Unfortunately, it is possible that the goal of the programs may be overlooked as administrators and others concentrate on developing and operating smoothly running programs. Without impact evaluations or long term followup the decision makers have little information on which to judge the effectiveness of their programs. Easily measurable and obtainable indicators of program performance, such as the number of persons completing the program, are used to gauge the success of program operations. The ability of program operators to meet administrative quotas are often the only measured indicators of effectiveness. Consequently, the administrators and operators of manpower programs may place a high priority on indicators which measure the effectiveness of program operation but not program impact.

The administrators of the PCEP operated the program under federal government supervision and guidelines. Flexibility in program design and funding allocations were limited. Manpower planning was not a responsibility of the PCEP personnel. The PCEP met federal requirements. There was no indication that the Portland CEP failed to perform satisfactorily in comparison with other federal manpower programs. Under federal programs functions such as job development, restructuring and anti-discrimination enforcement did not receive equal emphasis with manpower services intended to cause individual change. 
Recommendations for CETA Decision Makers

CETA, which places the functions of planning, administering and program operations in the hands of the prime sponsor, allows the prime sponsor to set new priorities and develop new policies. The first step might be a careful examination of the local labor market and the theories of low income labor markets. Programs such as the PCEP appear to be based on the queue theory of low income labor markets. "The queue theory asserts that workers are ranked according to the relationship between their potential productivity and their wage rate ... The most preferred workers are selected from the queue first, leaving the least preferred to find work in the least desirable jobs on the fringes of the economy or to remain unemployed." 114 The disadvantaged are among the least desired workers. Manpower programs emphasizing skill training and education assume that raising the productivity of the disadvantaged should move them forward in the queue and provide access to primary employment. CETA prime sponsors should devote careful study to the local labor market to determine whether the continuous model of the labor market as postulated by the queue theory is the most suitable to their area. If labor market mechanisms are working to expand the importance of primary employment and encouraging labor market mobility then this theory is appropriate as the basis for local policy. If the proportion or importance of secondary employment is large and 
increasing and barriers to mobility into the primary market are growing then policies which are based on the dual labor labor market theory postulates that the labor market is divided into a primary market-characterized by high wages employment stability, promotion opportunities, and due process in administration of work rulas - and a secondary market-characterized by low wages, high turnover, little opportunity for advancement, and arbitrary supervision. 116 Disadvantaged workers are confined to the secondary market by residence, poor skills and work histories, and discrimination. 117

If the local CETA prime sponsor adopts the dual labor market theory as the best explanation of the local low income labor market, the most appropriate manpower policies may differ from policies based on the queue theory. Policies based on the queue theory assume that expansion of aggregate demand and employment coupled with training to increase productivity may solve the employment problems of the disadvantaged. Policies developed from the dual labor market theory assume that expansion of the primary market has little effect on many of the disadvantaged. Instead, direct efforts must be made to facilitate the movements of workers out of secondary employment by altering worker characteristics and to convert secondary jobs into primary jobs. CETA sponsors should have an understanding of the 
above theories and a careful assessment of the characteristics and operation of the local labor market. Policies and priorities should be developed which are the most likely to yield positive results in their local labor markets.

If the queue theory of low income labor markets is adopted as most applicable to the local CETA labor market, then an effective CETA program may place a high priority on skills training to increase the productivity of the disadvantaged. Furthermore, manpower planners should carefully assess the local labor maxket to determine the occupations in which the programs' clientele have the best chances of obtaining satisfactory employment. Employers on the Planning Council might be requested to obtain data from their peers in the business community on how employees are trained, the length and content of the training and access points to employment. Training funds should not be utilized to train persons for jobs which are available without training. Before training courses are developed, the planner should obtain in-depth information about usual training methods. Working with employers, the planners and operators should develop training courses that provide equivalent training to that received by other applicants.

CETA prime sponsors should attempt to utilize whatever channels are available to local employers to obtain direct access to jobs which will provide satisfactory employment for manpower program participants. Job developers should 
meet with prospective employers and influence them to accept a reasonable match between job requirements and worker capabilities rather than pursuing unnecessary qualifications. If possible, programs which couple initial classroom training with on-the-job training should be developed. Internal labor markets of large local employers sh uld be carefully studied and strategies developed which remedy customary discrimination practices at entry points, in promotion, and in wage rates.

Regardless of the theory of the low income labor market adopted by the CETA sponsor, CETA decision makers might utilize manpower funds more effectively than did the PCEP by paying more serious attention to assessment of manpower program clientele. Accepting persons into the program on a first-come, first-served basis or with little consideration of services and jobs available results in a clientele with many diverse needs, interests and antitudes. Accepting persons who have a weak attachment to the labor force or with such severe barriers to employment as to make them unemployable is not the most effective use of manpower funds. The findings of this research suggest that persons ages 45 years and over may not be good prospective candidates for manpower programs. Females who are not heads of families may have a weak attachment to the labor force. An orderly, consistent system for making assessments of clients should be developed which considers physical and mental 
barriers to employment as well as the capabilities of the manpower program. The extent and severities of employment barriers serve as the ultimate cost of the necessary interventions and the prospects of success. The amount of manpower funds available set limits on what can realistically be done and manpower decision makers should recognize program limitations. Rather than process the maximum number of clients with little long term benefit to the participant, CETA sponsors should develop a strategy which considers available services and jobs as well as the target population applying to the program.

If the dual labor market theory is adopted as the basis for policy, the assessment of individual clients and the development of skill and behavioral traits appropriate to primary employment may receive high priority. Preference may be given to adult applicants with stable low wage work experience and young people who are entering the transitional period between unstable adolescence and the more mature stable patterns of adulthood required in primary employment. These two groups may be the easiest to place in primary employment. CETA sponsors may also focus on converting secondary employment into primary employment stabilizing jobs, building career ladders, increasing wage rates, etc. Unfortunately, the tools necessary to force this type of change are generally outside the control of a local prime sponsor. But, local prime sponsors could begin 
an active lobby at the state and federal level to encourage this process through application of minimum wage legislation, labor legislation, social security, and unemployment 119 compensation.

CETA sponsors should develop intervention strategies which most effectively improve the basic employability of individual clients, remove the institutional or systemic obstacles to employment for the disadvantaged, and create new public or private jobs for specific target groups. To concentrate only on individual employability may not have the expected impact on income.

Finally, the findings of this study demonstrate the potential value of impact evaluations. CETA prime sponsors should consider designing impact evaluations which would provide them with information on the effectiveness of their programs. Evaluations which include program monitoring would enable prime sponsors to determine what the impact of their programs are as well as probable explanations concerning why these impacts are occurring. Impact evaluations would enable the prime sponsor to reject unworkable projects and modify others to improve their effectiveness.

\section{SUMMARY}

Participation in the PCEP was of significant monetary benefit to thirteen percent of the participants included in 
this study in comparison to a control group. The groups which received benefit were:

- White males ages $0-20$ years with $1-9$ years of education

- Black females ages 26-44 years with over 12 years of education

- White females ages 26-44 with 10-11 years of education

- Black males ages 21-25 with 1-9 years of education

- Black females ages 21-25 years with 1-9 years of education

- White males ages 26-44 years with 10-11 years of education

- White females ages 26-44 years with 1-9 years of education

- White females ages 26-44 years with 12 years of education

Participation in the PCEP may have cost six percent of the participants. The groups in which the control group earned significantly more than the participant groups were:

- Black males ages 26-44 years with 10-11 years of education

- Black females ages 26-44 years with 1-0 years of education

- White males ages $0-20$ years with $10-11$ years of education

Over seventy percent of the persons included in this study earned incomes below the official poverty level of $\$ 4,540$ in 1973 for a nonfarm family of four. Participation did not raise the mean earnings of participant groups above the poverty level. The findings of this study suggest that the PCEP may have failed to train and place participants in jobs which provided above-poverty level incomes. The PCEP apparently trained and placed persons in jobs which offered no greater employment stability or higher incomes than jobs 
which participants may have attained without the manpower program.

Manpower decision makers should attempt to obtain access to satisfactory jobs for participants. High priority should be given to the functions of job development, job restructuring, anti-discrimination enforcement and job placement. An orderly, consistent system for making client assessments should be developed which considers physical and mental barriers to employment as well as the capabilities of the manpower program. 
FOOTNOTES - CHAPTER VI

112. U.S. Department of Commerce, Bureau of Census, 1970 Census of the Population: General Social and Economic Characteristics - Oregon (washington, D.C.: U. S. Government Printing Office, February, $1972)$, p. 191.

113. Ibid., p. 199.

114. Peter B. Doeringer and Michael J. Piore, Internal Labor Markets and Manpower Analysis (Lexington: D.C. Heath and Co., 1971), p. 165 .

115. Ibid., p. 169 .

116. Ibid., p. 165.

117. Ibid., p. 166.

118. Ibid., p. 179, 180.

119. Ibid., p. 181. 
Ackorf, Russell L. The Design of Social Research. Chicago: University of Chicago Press, 1953.

Alexander, Tom. "Social Engineers Retreat Under Fire", Fortune, October 1972 .

Bailey, Stephen K. Congress Makes a Law. New York: Columbia University Press, 1950.

Beers, Yardley. Introduction to the Theory of Error. Cambridge, Mass.: Addison-Wesley Publishing Co., Inc., 1953.

Blalock, Hubert M. Social Statistics. New York: McGraw-

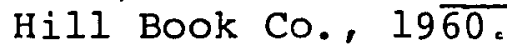

Bolino, August. Manpower and the City. Cambridge, Mass.: Schenkman Publishing Co., 1969.

Borus, Michael E., editor. Evaluating the Impact of Manpower Programs. Lexington: Lexington Books, 1972 .

Borus, Michael E., and Tash, William. Measuring the Impact of Manpower Programs. Ann Arbor: Institute of Labor and Industrial Relations, 1970.

Caro, Francis G., editor. Readings in Evaluation Research New York: Russell Sage Foundation, 1971.

Center for Population Research and Census, Portland State University, "Population Estimates of Counties and Incorporated Cities of Oregon", July 1974.

City of Portland Public Hearing on CETA I and II, Portland, Oregon, 24 December 1974.

Clifford, A.A. Multivariate Error Analysis. New York: John Wiley and Sons, 1973.

Courts, Frederick A. Psychological Statistics. Homewood, Illinois: Dorsey Press, 1966. 
SOURCES CONSULTED (Continued)

Davidson, Roger $\mathrm{H}$. The Politics of Comprehensive Manpower Legislation. Baltimore: Johns Hopkins Press, 1972.

Dewey, John. The Public and Its Problems. Chicago: Gateway Books, 1946 .

Doeringer, Peter B., editor. Programs to Employ the Disadvantaged. Englewood Cliffs, N.J.: Prentice Hall, Inc., I969.

Doeringer, Peter B., and Piore, Michael J. Internal Labor Markets and Manpower Analysis. Lexington, Mass.: D.C. Heath and Co., 1971.

Ferber, Robert, and Verdoorn, P.J. Research Methods In Economics and Business. New York: Macmillan Co., 1962.

Friedlander, Stanley. Unemployment in the Urban Core. New York: Praeger Publishers, 1972.

Fryer, H.C. Concepts and Methods of Experimental Statistics. Boston: Allyn and Bacon, Inc., I966.

Gordon, Robert Aaron. The Goal of Full Employment. New York: John Wiley and Sons, 1967.

Hamermesh, Daniel S. Economic Aspects of Manpower. Lexington, Mass.: D.C. Heath and Co., 1971.

Hays, William A., and Winkler, Robert L. Statistics, Volume II. New York: Holt, Rinehart and Winston, Inc., 1970 .

Holt, Charles C., et. al. The Unemployment Inflation Dilemma: A Manpower Solution. Washington, D.C.: Urban Institute, 1971.

Jones, Charles 0 . Introduction to the study of Public Policy. Belmont, Calif.: Wadsworth Pub., 1970.

Kirk, Roger E. Experimental Design: Procedures for the Behavioral Sciences. Belmont, Calif.: Brooks/Cole Publishing Co., 1969.

Lee, Wayne. Experimental Design and Analysis. San Francisco: W.H. Freeman and Co., 1975. 
SOURCES CONSULTED (Continued)

Levitan, Sar A. Federal Aid to Depressed Areas. Baltimore: Johns Hopkins Press, 1964.

Levitan, Sar A. Making Sense of Federal Manpower Policy. Ann Arbor: Institute of Labor and Industrial Relations, 1967.

Levitw, Sar A., and Siegel, Irving. Dimensions of Marpower Policy: Programs and Research. Baltimore: Johns Hopkins Press, 1966. Hopkins Press, 1966.

Levitan, Sar A., and Taggert, Robert III. Social Experimentation And Manpower Policy: The Rhetoric and the Reality. Baltimore: Johns Hopkins Press, 1971.

Levitan, Sar A.; Mangum, Garth L.; and Marshall, Ray. Human Resources and Labor Markets. New York: Harper and Row, Publishers, 1972.

Levitan, Sar A., and Taggert, Robert, editors. The Emergency Employment Act. Salt Lake City: olympus Publishing Co., 1974.

Lindblom, Charles E. The Policy Making Process. Englewood Cliffs, N.J.: Prentice Hall, 1968.

Mangum, Garth I. MDTA. Baltimore: Johns Hopkins Press, 1968.

- The Emergence of Manpower Policy. New York: Holt, Rinehart and Winston, Inc., 1969.

- Contributions and Costs of Manpower. Ann Arbor: Institute of Labor and Industrial Pelations, 1967.

- Manpower Planning for Local Jabor Markets. Salt Lake City: Olympus Publishing Co., 1975.

, editor. The Manpower Revolution. Garden City, N.Y.: Doubleday and Co., 1965.

Mangum, Garth L., and Walsh, John. A Decade of Manpower Development and Training. Salt Lake City: Olympus Publishing Co., 1973. 
SOURCES CONSULTED (Continued)

Manpower Report of the President. Washington, D.C.: U.S. Government Printing Office, 1974, 1975.

McLennan, Kenneth, and Seidenstat, PauI. New Business and Urban Employment Opportunities. Lexington, Mass.: D.C. Heath and Co., 1972 .

Mirengoff, William, and Rindler, Lester. The Comprehensive Employment and Training Act. Washington, D.C.: Printing Publishing Office, National Academy of Sciences, 1976.

Multnomah Washington Manpower Consortium, Modified Grant Application to Manpower Administration, U.S. Department of Labor, Seattle, January 1975.

Oaxaca, Ronald. Male-Female Wage Differentials in Urban Labor Markets. Springfield: National Technical Information Service (PB 199974), 1971.

Olympus Research Corporation. The Total Impact of Manpower Programs: A Four City Case Study. Washington, D.C.: U.S. Department of Labor, August 1971.

Palumbo, Dennis J. Statistics in Political and Behavioral Sciences. New York: Meredith Corp., 1969.

Rondinelli, Dennis A. "Urban Planning As Policy Analysis: Management of Urban Change", American Institute of Planners Journal 39 (January 1973):19-28.

Rossi, Peter H., and Williams, Walter. Evaluating Social Programs. New York: Seminar Press, Inc., 1972.

Scanlon, John W., et al. An Evaluation System to Support Planning, Allocation and Control in a Decentralized Comprehensive Manpower Program. Washington, D.C.: The Urban Institute, 1971.

Schuessler, Karl. Analyzing Social Data. Boston: Houghton Mifflin Co., 1971.

Somers, Gerald G., editor. Retraining the Unemployed. Madison: University of Wisconsin Press, 1968.

Sundquist, James L. Politics and Policy. Washington, D.C.: Brookings Institute, 1968. 
SOURCES CONSULTED (Continued)

Ulman, Lloyd, editor. Manpower Programs in the Policy Mix. Baltimore: Johns Hopkins Press, 1973.

U.S., Congress, House of Representatives, Committee on Education and Labor, Manpower Development and Training Act Extension, June 18, 1973: Report Together with Minority, Additional and Dissenting Views. 93rd Cong., lst Sess., 1973.

U.S., Congress, Senate, Special Committee on Unemployment Problems. Hearings, Studies in Unemployment, Readings in Unemployment, and Report No. 1206 prepared pursuant to Senate Resolution 196, 86th Cong., 2nd Sess., 1960.

U.S., Congress, Senate, Subcommittee on Employment and Manpower of the Committee on Labor and Public Welfare, United States Senate, Toward Full Employment: Proposals for a Comprehensive Employment and Manpower Policy in the United States, 88th Cong., 2nd Sess., 1964.

U.S., Congress, Senate, Subcommittee on Employment and Manpower of the Committee on Labor and Public Welfare, United States Senate, History of the Employment and Manpower Policy in the United States: Twenty Years of Experience Under the Employment Act of 1946, Volume 7, Part II of Selected Readings in Employment and Manpower, 80th Cong., 2nd Sess., 1966.

U.S. Department of Commerce, Bureau of Census, 1970 Census of the Population: General Social and Economic Characteristics. Washington, D.C.: U.S. Government Printing Office, 1972.

U.S. Department of Labor, "The New Manpower Bill: A Summary", Manpower, October 1972 .

Williams, Walter. Social Policy Research and Analysis. New York: American Elsevier Publishing Co., 1971.

Winer, B.J. Statistical Principles in Experimental Design. New York: McGraw-Hill Book Co., 1962.

INTERVIEWS

Interview with Delmer Smith, Director, Concentrated Employment Program, Portland, Oregon, 9-10 May, 1974. 
INTERVIEWS (Continued)

Interview with Patrick Borunda, Manpower Director for City of Portland, Portland, Oregon, 10 February 1975.

Interview with Cleveland Gilchrist, Director, Portland Metropolitan Steering Commission, Portland, Oregon, 10 February 1975.

Interview with Susan Wagenblast, Counselor, Portland opportunities Industrialization Center, Portland, Oregon, 10 February 1975.

Interview with Jack Wills, Director, Multnomah Washington Manpower Consortium, Portland, Oregon, 11 February 1975.

Interview with Joe White, Manpower Aide to City of Portland Commissioner Charles Jordan, Portland, Oregon, 18 February 1975.

Interview with Charles Jordan, City of Portland Commissioner, Portland, Oregon, 20 February 1975.

Interview with Phil McLarin, Aide to City of Portland Mayor Neil Goldschmidt, Portland, Oregon, 28 February, 1975.

Interview with Larry Macnab, Executive secretary for the Oregon Balance of State Manpower Plan, Salem, Oregon, 20 March 1975.

Interview with Ken Rucker, U.S. Department of Labor Region X, Seattle, Washington, 11 June 1976. 